

\section{New from the Centre for Co-operation with European Economies in Transition (CCEET)}

\section{SHORT-TERM ECONOMIC INDICATORS CENTRAL AND EASTERN EUROPE}

This new quarterly provides a range of short-term economic indicators for five transition countries in central and eastern Europe - Bulgaria, the former Czech and Slovak Federal Republic, Hungary, Poland and Romania.

Data are provided for industrial production, construction, employment, earnings, prices, domestic and foreign finance, interest rates and domestic and foreign trade.

Subscription:

(07 9300 3) ISSN 1019-9829, FF120 £16 US\$28 DM52

\section{TRENDS AND DEVELOPMENTS IN PRIVATISATION}

The aim of this forthcoming periodical is to keep readers informed of developments in the fast-moving field of privatisation in central and eastern European countries, and to serve as a basis for analytical discussion of the privatisation process as well as to highlight important innovations. It will provide summary data on the extent of transformation, restructuring, and privatisation activity. Of particular importance will be the sections reporting regularly on institutional and methodological innovations.

Subscription:

(00 9300 0) ISSN 1021-3287, FF150 £20 US\$30 DM50

\section{VALUATION AND PRIVATISATION}

This volume reviews development in accounting and valuation. Based on recent experience in central and eastern European economies, it discusses the main methods of asset and business evaluation and their application in a period of transition and economic uncertainty.

(14 9302 1) ISBN 92-64-13818-8, 120pp.

FF100 £17 US\$24 DM40

\section{Also available:}

\section{REGIONAL DEVELOPMENT PROBLEMS AND POLICIES IN POLAND}

January 1993

(14 9203 1) ISBN 92-64-13807-2, 68pp.

FF60 £10 US\$15 DM25

INDUSTRY IN POLAND. Structural Adjustment Issues and Policy Options

October 1992

(14 9204 1) ISBN 92-64-13755-6, 186pp.

FF170 £25 US\$44 DM70

REVIEW OF NATIONAL SCIENCE AND TECHNOLOGY POLICY:

Czech and Slovak Federal Republic

December 1992

(14 9208 1) ISBN 92-64-13796-3, 200pp.

FF180 £30 US $\$ 44$ DM75

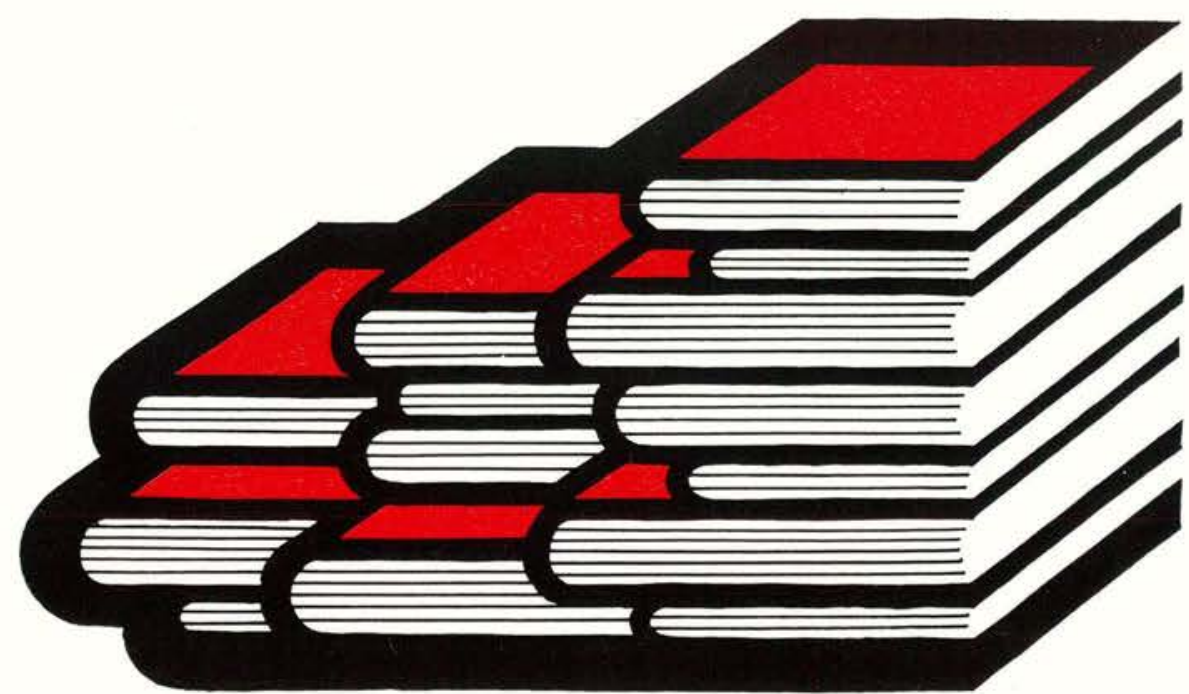






Published every two months in English and French by the ORGANISATION FOR ECONOMIC CO-OPERATION AND DEVELOPMENT

Editorial Address:

OECD Publications Service

Château de la Muette

2 , rue André-Pascal

F 75775 PARIS CEDEX 16

Tel. (33 1) 45248200

Fax $(331) 45248500$

Individual articles not copyrighted may be reprinted, provided the credit line reads

'Reprinted from The OECD Observer' plus date

of issue and two voucher copies are sent to the

Editor, with an indication of the circulation.

Signed articles reprinted must bear the author's

name.

Signed articles express the opinions of the

authors and do not necessarily represent the

opinion of the OECD.

The Organisation cannot be responsible for

returning unsolicited manuscripts.

All correspondence should be addressed

to the Editor.

Single copies

£2.50 US\$5.00 FF22.00 DM9.00

Annual Subscription Rates

£13.00 US\$24.00 FF110.00 DM46.00

Tel. (33 1) 45248166

Editor

Ulla Ranhall-Reyners

Associate Editor

Martin Anderson

Assistants

Yannick Bultynck

Carol Thornton

Art, Production and Layout

Gérald Tingaud

Photo Research

Silvia Thompson

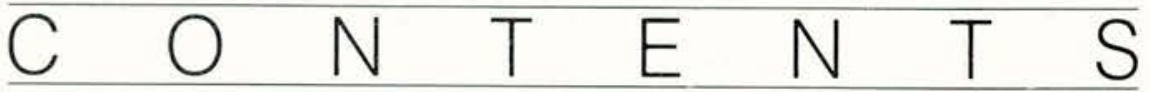

trade

4

WHAT PRICE REGIONAL INTEGRATION?

Nicholas Vanston

energy

8

QUALIFIED MANPOWER FOR THE NUCLEAR INDUSTRY

Nicholas Zarimpas

11

TECHNOLOGICAL SPIN-OFFS FROM NUCLEAR ENERGY

Pierre Girouard

urban affairs

14

CITY LIMITS

Rémy Prud'homme

finance

18

THE EMERGING BOND MARKETS

OF SOUTH-EAST ASIA

S. Ghon Rhee

education

23

RADICAL REFORM FOR SWEDISH EDUCATION

George Papadopoulos

27

CITIES FOR LEARNING

Donald Hirsch

transport

30

MARKETING TRAFFIC SAFETY

Antonios Barbas and Burkhard Horn

economies in transition

33

THE ENVIRONMENT IN EASTERN EUROPE:

FROM RED TO GREEN?

Ferenc Juhasz and Aldea Ragno

\section{economy}

37

INDICATORS

39

NEW OECD PUBLICATIONS

181

April/May 1993

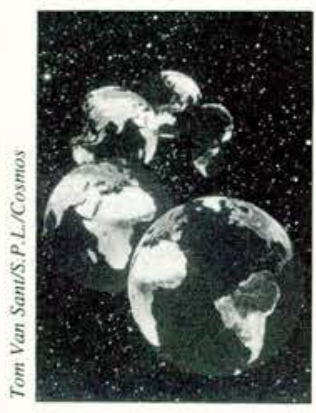

Cover

Regional agreements between neighbouring countries may appear to lead to increased trade and economic growth. But they have costs, not least by raising barriers against third parties. 


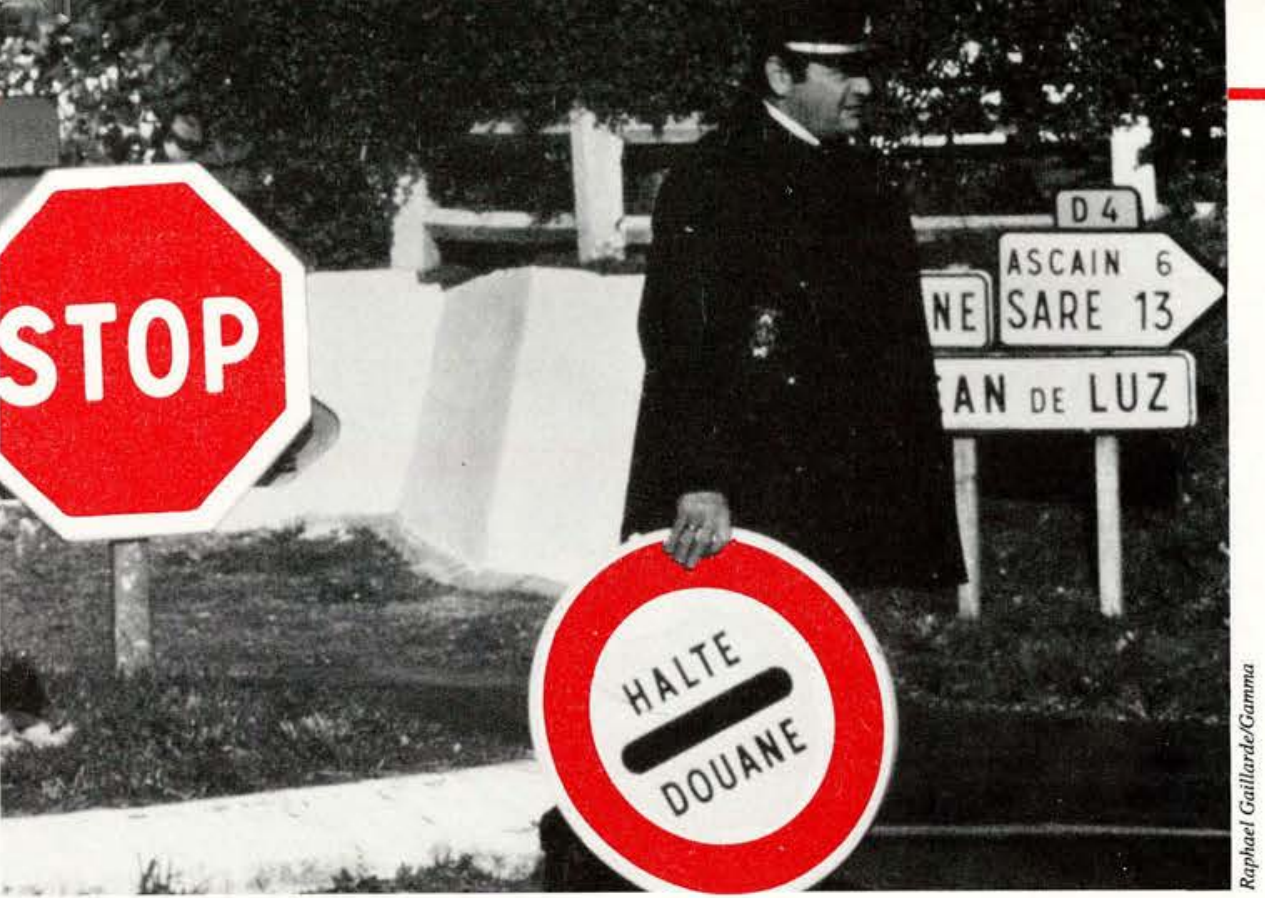

\title{
What Price
}

\section{Regional Integration?}

\begin{abstract}
Nicholas Vanston
EC, EFTA, NAFTA, ASEAN - all these abbreviations are related in one way or another to the much talked-about phenomenon of 'regional integration', the tendency of economic linkages with neighbouring countries to grow faster than with more distant countries and regions. What is the economic reality behind these alliances?
\end{abstract}

$\mathbf{T}$ he first task for the analyst of regional integration is to see if, or to what extent, it is taking place. For trade in visible goods, that is easy enough, since trade statistics for almost every country in the world are of high quality and go back many years. And they do show that, by whatever criterion, trade between some neighbouring countries has expanded more rapidly than with trading partners further away.

This is especially true of European countries, whose trade with one another is now well over half their total trade, and still increasing. It is also true, but to a lesser extent, for Canada plus the United States and Mexico, which now make up the NAFTA (North American Free Trade Area) group, and of newly industrialising countries in south-east Asia.
The picture elsewhere in the world is more mixed. Trade between central and eastern European countries, and between them and republics of the former Soviet Union, has fallen precipitously, while trade between neighbouring developing countries is usually quite low and shows no overall tendency to rise or fall.

As with trade in goods, many analysts and commentators are interested in trade in services and foreign investment. In these areas, matters are much less clear cut. The data show a rather weaktendency for trade in services of European countries to become more regionally concentrated, especially since the mid-1980s, but there seems to be no such regional trend in

Nicholas Vanston is Head of the Foreign Trade and Investment Division in the Economics Department of the OECD.
North America. Foreign direct investment (FDI) flows rose very rapidly in the 1980 s and until recently, but they seem to be as much global as regional. Japan, for example, invests heavily in the Asian region, but even more so in the United States and Europe, while the United States invests far more in Europe than it does in Canada and Mexico - although investment flows to Mexico in particular rose very quickly even before the NAFTA agreement was signed (although it has not yet been ratified).

There are several reasons that governments should be interested in regional integration. In some cases - for example, Europe in the 1950s and south-east Asia at the moment - the integration process seems to be a spontaneous phenomenon, led by market 
forces and associated with unusually rapid economic growth. Since prosperity for one region can spill over into others, policy-makers everywhere have to be informed, so that their own countries can take advantage of booms elsewhere, and establish themselves in what promise to become important markets.

In other instances, the spontaneous process has been encouraged by intergovernmental agreements that lower trade barriers between the countries concerned. This was the case with the European countries which joined together to form the European Economic Community and then the European Free Trade Agreement (EFTA) grouping at the beginning of the $1960 \mathrm{~s}$. In yet other cases, neighbouring governments grant privileged status to trade with each other, even if such trade is not expanding rapidly by itself, in the expectation that this will lead to increased trade and prosperity. Many developing countries signed agreements of this sort, particularly in the 1960 s and '70s.

\section{Trade Creation, Trade Diversion}

Although it might be thought that any agreement that lowers trade barriers between a group of countries must benefit them without harming others, that is not necessarily the case. Indeed, Article 24 of the General Agreement on Tariffs and Trade (GATT) lays down strict criteria for such agreements to be compatible with the multilateral trading system.

There are two main reasons that other countries have to be vigilant. One is that the integrating countries may be tempted to raise trade barriers against third countries at the same time that they lower them between themselves - the 'fortress' syndrome. The usual result of this practice is that the integrating countries do themselves at least as much damage as they inflict on others, because they artificially cut themselves off from world

\footnotetext{
1. 'The Economics of Customs Unions', The Customs Union Issue, Carnegie Endowment for International Peace, Washington DC, pp. 41-55.

2. Regional Integration and Developing Countries: An Inside and Outside Perspective, OECD Publications, Paris, forthcoming 1993.
}

competition. The poor economic performance of central and eastern European countries in the post-War period was undoubtedly due, among other things, to the barriers erected against imports from the West while trade among them was encouraged by the Comecon system.

The second reason is that even when trade barriers against third countries are not raised, regional agreements can inflict damage on other countries. The Canadian economist Jacob Viner first pointed this out in 1950, when he showed that a selective lowering of trade barriers will lead to trade distortions. ${ }^{1}$ When tariffs are uniform, each country will import from the lowest-cost source, although paying a higher price than with complete free trade. When tariffs on imports from some countries are lower than from others, the importers will buy from the country that offers the lowest price, which is not necessarily the one that can produce at the lowest cost. This 'trade diversion' is an inevitable consequence of regional trade agreements, and it is important to establish whether or not it is more than offset by 'trade creation', the extra trade and prosperity generated within the region by the lowering of barriers.

This is an empirical question, and a difficult one to resolve, for answering it requires knowledge of what would have happened in the absence of the regional agreement. The general consensus among analysts is that, as far as the EC and EFTA are concerned, trade creation has exceeded trade diversion since the two organisations were created.

But the institutional framework can affect the outcome. The major driving force behind regional trade agreements in Africa and Latin America, not least in the 1960s and '70s, was the belief that by banding together and creating a large regional market, each country would be able to exploit economies of scale. An OECD study undertaken over the past two years has concluded that, in almost all of these cases, trade diversion had been substantially higher than trade creation, leaving all countries worse off. ${ }^{2}$ This was because they usually involved explicit or implicit raising of trade barriers with other countries, and because individual countries were unwilling to allow uncompetitive industries to wither away so that the more competitive industries of their neighbours could expand.

In some respects, though, the traditional 'trade creation/trade diversion' analysis is less relevant than it used to be. Tariffs on trade in goods between OECD countries are now very low, and lowering them further would have little overall impact. The sorts of regional agreements now being forged go well beyond the straightforwardagreements to lower tariffs on trade in goods. NAFTA, for example, deals with non-tariff barriers to trade in

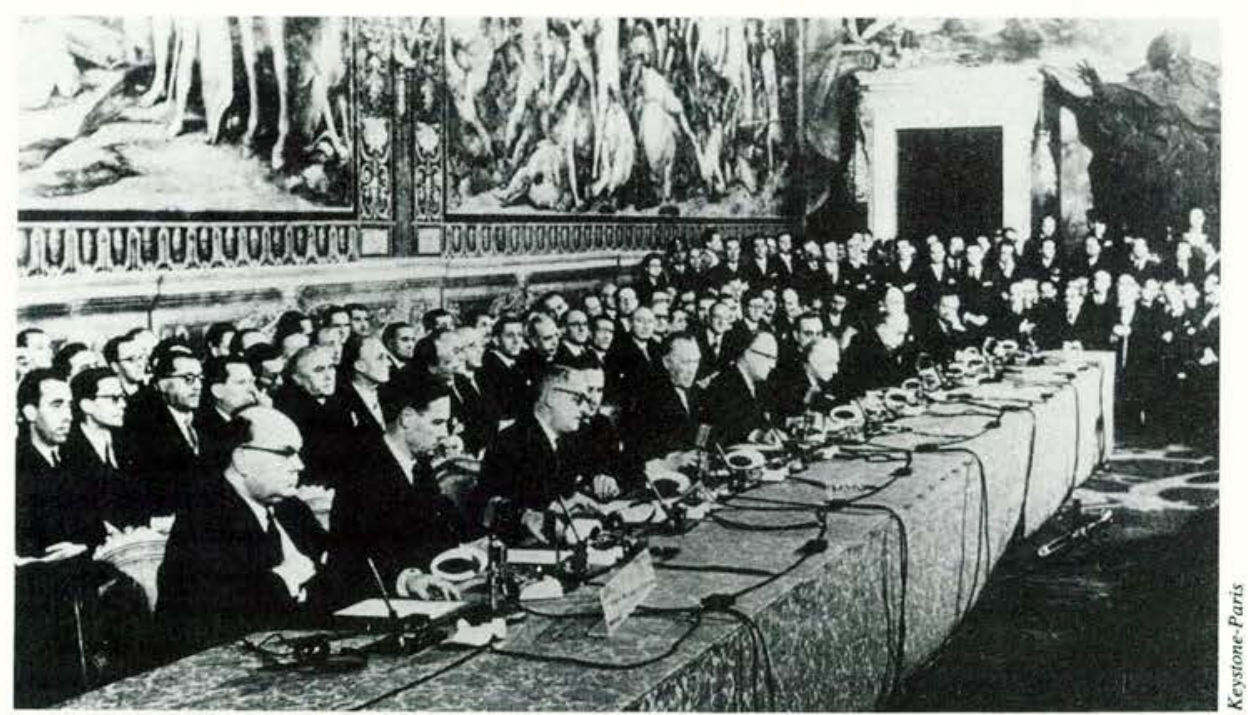


agricultural goods and textiles, with trade in services, with investment flows, even with environmental regulations.

The EC92 ('Single Market') programme goes even further, abolishing customs formalities altogether for trade between EC countries, encouraging the free movement of labour across EC frontiers, harmonising professional and industrial standards, and encouraging competition in general. Even before the EC92 programme, the EC Commission had exercised its powers to monitor national legislation to ensure that it is not in conflict with Community aims. Competitiondistorting subsidies to industries or regions, or mergers that could lead to market dominance, are typical examples of practices that the Commission was long ago given powers to investigate and, if necessary, to forbid.

\section{What Effects on Structural Reform?}

Indeed, the recent regional agreements involving OECD countries are perhaps best thought of as a means of encouraging structural reforms within countries by subjecting the private sector to increased competition in as many areas as possible. But that does not necessarily require a regional trade agreement. Domestic competition laws can be strengthened unilaterally, and/or a country can unilaterally open its borders to competition from other countries.

However it occurs, structural reform is a painful process, at least at the beginning, since there are losses as well as gains. One advantage of regional agreements is that the necessity for, and advantages of, reforms are more readily perceived, probably quicker to be realised and, because reforms feed on one another, their realisation is probably quicker if several countries are involved. There is also the purely political point that when reforms are unpopular, national governments can shield themselves behind the regional agreement.

Regional agreements have many supporters and some powerful critics. The supporters believe strongly that the structural reforms they involve, beyond



their merely domestic benefits, will also benefit third countries, in two ways. Their imports from the region will fall in cost as the regional companies become more efficient at producing those goods, while higher production and incomes within the region will result in higher imports from third countries. Third countries will thus have higher exports and cheaper imports.

Yet the calculations made by analysts tend to show that benefits to third countries from the EC and NAFTA, for example, are not particularly large, although the projected benefits to the participating countries are substantial. Many economists believe that regional free-trade agreements, especially those that spur competition across many sectors and not only trade in goods, will lead not only to higher output and incomes in the medium-term, but even to faster potential growth rates over the long term. This argument has generated some interesting analysis, but it remains for the moment an unproven hypothesis.

The critics of regional agreements view all regional agreements as essentially discriminatory and contrary to the principles of free multilateral trade enshrined in the GATT articles. They point to the failure of many regional agreements to achieve their objectives in the past, and worry that during the adjustment phase of the current ones, some sectors in North America and Europe will try to ease the pain of adjustment to increased competition from other countries within the region by shutting out competition from third countries. ${ }^{3}$

This danger cannotbe ignored, although for the moment it does not seem to be an immediate threat. It has nonetheless largely been agreed that for regional agreements to confer the benefits that their proponents claim, adjustment must take place: there is 'no gain without pain'. If efficient firms are to expand, or economies of scale are to be reaped, some firms have to contract. If they are helped to survive by subsidies or other forms of protection, the benefits will be small or non-existent.

Another worry is that as a result of regional trade agreements, the world will split up into regional 'trading blocs' - say, North America, Europe and a formal or informal bloc comprising Japan and some

3. Barrie Stevens, 'Strategic Industries: What Policies for the 1990s?', The OECD Observer, No. 172, October/ November 1991. 
other Asian countries. Within each bloc, trade would be essentially free, subject only to market forces. Trade between blocs, and between them and countries that were not members of any bloc would be 'managed', that is, subject to official agreements on quantities, prices and sources. Each bloc would perceive the other blocs as enemies rather than as trading partners, the multilateral trading system would break down, and the world would relapse into the trade wars of the 1930s.

Happily, there is little evidence that this is happening. Although it is true that trade in goods is becoming more regionally concentrated, trade between regions is still expanding, and trade in services and investment flows remain essentially global rather than regional in character. The fear that regional trade blocs could emerge has nevertheless tended to encourage countries that are not currently members of a regional trade agreement either to join one of the large blocs, or to band together to form one for themselves. It is said, too, that the flow of foreign investment into North America and Europe is motivated in part by the fear that, one day, only those companies that have production facilities within these large markets will be able to continue selling there. In this view, pressure to join existing regional agreements or to invest in other regions owes as much to prudence and fear of loss as to hopes of gain.

\section{Regional Agreements and the GATT}

But the main motive in practice does seem to be the expectation that freer trade within regions will lead to higher competition, lower costs and higher incomes. Still, arriving at a satisfactory agreement can be a long-drawn-out process, and policing it so that it will work requires constant vigilance once the agreement has been signed. Unless there is a powerful central authority, such as the EC Commission, or a good deal of good will, experience shows that sovereign governments will put their own national interests first when times become hard. If this is the case, why do countries not put all this effort into reaching multilateral, rather than regional, agreements, where the potential gains are even higher, and where there exists the respected centralising institution of the GATT?

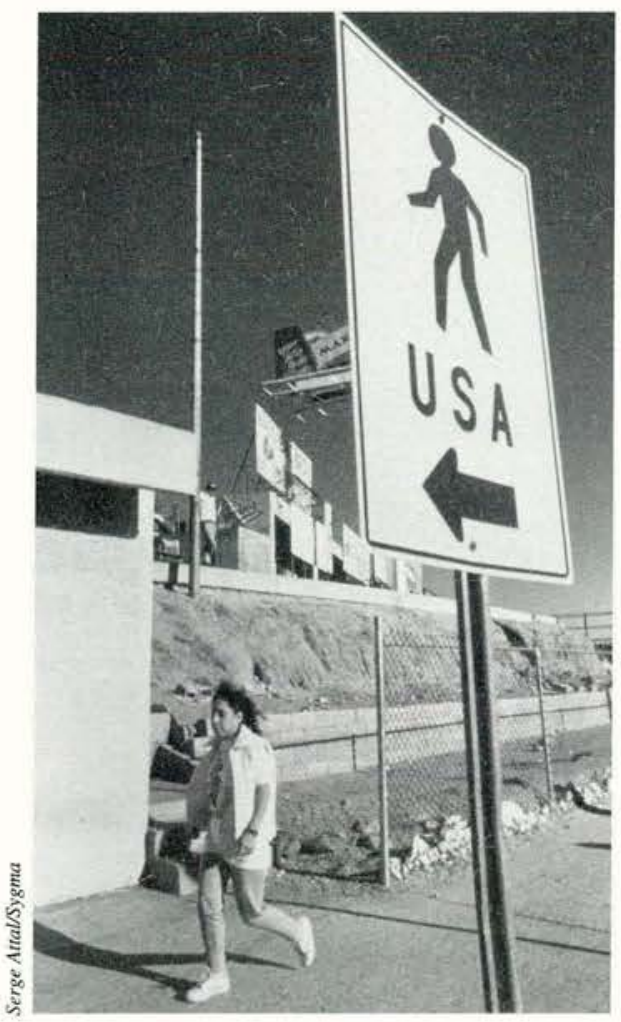

The answer seems to be that the GATT is to some extent a victim of its own success in reducing tariff barriers through successive 'GATT Rounds' in the post-War period. Tariffs between OECD countries, who are by far the major players in world trade, are now very low, and the membership of GATT is very much higher than it used to be.

It is becoming increasingly difficult in practice, as the Uruguay Round in its early stages showed, to get the newer members even to agree to discuss some of the more recent issues that have become the focus of interest for OECD countries. These new topics include trade in services, including financial services, intellectual property rights, and direct investment guidelines. OECD countries are finding it far easier to negotiate agreements in these areas between 'like-minded friends' who have similar economic structures and similar ways of looking at economic policy problems.

The expectation is that experience gained in negotiating these regional agreements, and experience of how they work in practice, will one day serve as a guide for more ambitious multilateral agreements. In that sense, regional agreements are a 'stepping stone' rather than a 'stumbling block' to further progress in the multilateral world trading system.

Whatever the hypothetical merits or dangers of regional trade agreements, almost every OECD country, and an increasing number of non-OECD countries, are now members of such agreements - and more are under discussion. The issue for policy-makers is therefore how to harness them so that they confer the maximum benefit on the world, with the minimum of distortion. Experience shows that the answer is vigilance and peer-pressure while they are being negotiated, continuing once they have been set up. Fortunately, there are institutions such as the GATT and the OECD, where such multilateral surveillance of domestic and regional policies that can affect neighbours takes place continuously.



OECD Bibliography

Regional Integration and Developing Countries: An Inside and Outside Perspective, forthcoming 1993 - John West, 'Economic Integration: Three Actors on the Intemational Stage', The OECD Observer, No. 180,

February/March 1993

- Strategic Industries in a Global Economy: Policy Issues for the 1990s, 1991

- Barre Stevens, 'Strategic Industries: What Policies for the 1990s?', The OECD Observer, No. 172, October/ November 1991 


\section{Qualified Manpower for th the Nuclear Industry}

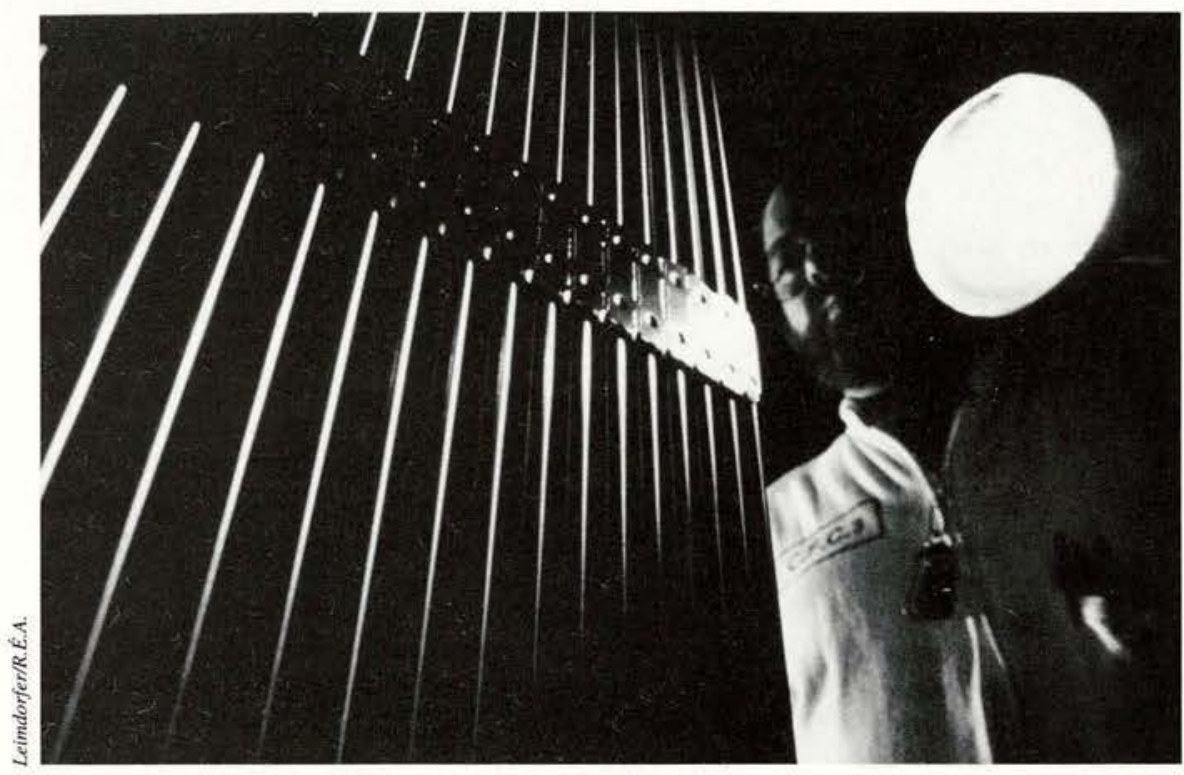

There is growing concern in OECD countries and elsewhere that the nuclear industry may soon encounter difficulties in recruiting - and keeping - qualified staff. How can a balance be ensured between supply and demand?



he operation of nuclear power plants, which generate between 20 and $73 \%$ of the electricity consumed in OECD countries, and the increase of activities required for the efficient and safe management of radioactive nuclear waste, regulation, extending the life of power plants and decommissioning them - all necessitate a continuous supply of qualified personnel. In addition, upgrading the badly maintained nuclear facilities in central and eastern Europe and the former Soviet Union will result in a considerable strain on the available manpower.

At present, the supply of, and demand for, qualified manpower are reasonably well balanced. But there is concern in a number of OECD countries that the flow of entrants into professions in nuclear energy may begin to fall away, through the retirement of experienced scientists and engineers and the declining numbers of graduates in the requisite disciplines.

A pioneering country-by-country enquiry undertaken by the OECD Nuclear Energy Agency (NEA) has examined the situation of qualified manpower with

\section{Nicholas Zarimpas}

professional occupations as engineers and scientists (with at least a first degree, or equivalent). The enquiry explored seven activities related to nuclear generation of electricity (Front-end; Back-end; ${ }^{2}$ Plant Operation and Maintenance; Design, Manufacturing and Construction; Regulation; R\&D and Education; and 'Others'). Occupations in these major sectors were further classified as engineers (nuclear and chemical, for example), scientists (physicists, chemists, and so on), and managers.

Belgium, Canada, Finland, France, Germany, Japan, the Netherlands, Spain, Sweden, Switzerland, the United Kingdom and the United States all provided statistics. Since only a few countries maintain comprehensive data bases, the coverage and detail of the information

Nicholas Zarimpas works in the Nuclear Development Division of the OECD Nuclear Energy Agency. varied. They nonetheless supported a number of general observations.

The manpower position in each country (Table) depends, obviously, on the size of its nuclear programme. And differences in the distribution of employment by sector reflect the difference of structures of the nuclear industries. The figures were compared internationally, sector by sector, in relation to the scale of activities undertaken, such as generation capacity. And although the definitions of qualified manpower varied from country to country, the numbers 'per unit of activity' were not in general spread over a wide range.

The age-structures of qualified manpower were also examined. It was apparent that in some countries a large proportion of the work-force is nearing retirement (Figure, p. 10), much more

1. Qualified Manpower for the Nuclear Industry: An Assessment of Demand and Supply, NEAVOECD Publications, Paris, forthcoming 1993.

2. The 'front end' of the nuclear fuel cycle entails uranium mining and milling, conversion, enrichment and fuel fabrication; the 'back end' involves the processing of spent fuel and disposing of waste.

3. OECD Nuclear Energy Data, NEANOECD Publications, Paris, 1992 
The many stages of the nuclear cycle, from the production of fuel (left) to the surveillance of safety procedures (right), require a steady supply of qualified personnel.

so among personnel in nuclear energy and related activities than in other industries, and will thus probably lead to marked losses of qualified manpower in the very near future.

\section{Balancing Demand and Supply}

For most of the countries for which data were available, the numbers of qualified manpower up to the year 2005 are expected to be stable or to increase slightly. There are two exceptions: Japan, where the demand is expected to increase rapidly because of the nuclear programmes expanding into the $21 \mathrm{st}$ century, and the United States, where an increase is expected to arise from employment in the back-end sector, mainly attributed to the increase in the programme for management of radioactive waste.

The rate of commissioning of new plants reached a peak in the early 1980 s, and forecasts ${ }^{3}$ indicate that relatively fewer plants will be commissioned in the near future. It might have been thought that, at least in the short term, this would have reduced pressure on the available supply of qualified manpower.



Yet even if there is no expansion of total nuclear generation, it seems that it will be increasingly difficult to maintain the current balance. It is true that the demand for design and construction will not be as strong as in the past. But, in addition to maintenance and operation, considerable attention is going to be given to the means of extending the operating lives of power plants and to upgrading them.

Demand for decommissioning obsolete plants will also begin to rise, as it will also at the back-end of the fuel cycle (mainly reprocessing and waste disposal). And that may well be accompanied by some increase in demand for regulators (for instance, engineers working in the development of regulation for the design and operation of relevant facilities). Pressure for foreign sales, $R \& D$ and education and training will probably continue but appears unlikely to have any major impact on the overall balance.
On the supply side, most countries report a decrease in the number of graduates from nuclear-related departments of universities (courses which are devoted to, or have a large segment of, nuclear engineering, nuclear chemistry or physics); moreover, the number of universities offering such courses has also decreased. Some qualified personnel can be drawn from other sectors such as the other electric utilities, chemical and construction companies, and so on - to be trained by the nuclear industry. But there are doubts that this process will offset the declining supply, which will be exacerbated if the general tendency of students in some countries to shun technological education persists.

\section{Securing Manpower}

Environmental and economic considerations, coupled with decisions in energy policy, the expected growth in demand

\section{Table}

QUALIFIED MANPOWER IN THE NUCLEAR INDUSTRY, 1990

\begin{tabular}{|c|c|c|c|c|c|c|c|c|c|c|c|c|c|c|c|c|}
\hline & \multicolumn{2}{|c|}{ Front-end } & \multicolumn{2}{|c|}{ Back-end } & \multicolumn{2}{|c|}{$\begin{array}{l}\text { Plant Operation } \\
\text { and Maintenance }\end{array}$} & \multicolumn{2}{|c|}{$\begin{array}{c}\text { Design, } \\
\text { Manufacturing, } \\
\text { Construction }\end{array}$} & \multicolumn{2}{|c|}{ Regulation } & \multicolumn{2}{|c|}{$\begin{array}{c}\text { R\&D, } \\
\text { Education }\end{array}$} & \multicolumn{2}{|c|}{ Other } & \multicolumn{2}{|c|}{ Total } \\
\hline & No. & $\%$ & No. & $\%$ & No. & $\%$ & No. & $\%$ & No. & $\%$ & No. & $\%$ & No. & $\%$ & No. & $\%$ \\
\hline Belgium & 44 & 5.1 & 91 & 10.6 & 216 & 25.1 & 343 & 39.9 & 57 & 6.6 & 109 & 12.7 & 0 & 0.0 & 860 & 100 \\
\hline Canada & 281 & 8.7 & 33 & 1.0 & $1,154^{\mathrm{a}}$ & 35.7 & 811 & 25.1 & 280 & 8.7 & 673 & 20.8 & 0 & 0.0 & 3,232 & 100 \\
\hline Finland & 0 & 0.0 & 95 & 24.1 & 146 & 37.1 & 0 & 0.0 & 60 & 15.2 & 93 & 23.6 & 0 & 0.0 & 394 & 100 \\
\hline France ${ }^{1}$ & 511 & $\cdots$ & 542 & $\cdots$ & 4,219 & $\cdots$ & 1,700 & $\cdots$ & $\cdots$ & $\cdots$ & 2,269 & $\cdots$ & $\cdots$ & $\cdots$ & $\cdots$ & .. \\
\hline Japan & 287 & 2.9 & 329 & 3.3 & 900 & 9.1 & 5,410 & 55.0 & 444 & 4.5 & 2,473 & 25.1 & 0 & 0.0 & 9,843 & 100 \\
\hline Netherlands & 61 & 14.8 & 7 & 1.7 & 111 & 26.9 & 52 & 12.6 & 15 & 3.6 & 91 & 22.0 & 76 & 18.4 & 413 & 100 \\
\hline Sweden & 132 & 8.1 & 34 & 2.1 & 755 & 46.6 & 310 & 19.1 & 87 & 5.4 & 303 & 18.7 & 0 & 0.0 & 1,621 & 100 \\
\hline Switzerland & 0 & 0.0 & 65 & 9.2 & 265 & 37.4 & 158 & 22.3 & 83 & 11.7 & 124 & 17.5 & 13 & 1.8 & 708 & 100 \\
\hline United Kingdom & 649 & 4.6 & 1,041 & 7.4 & 3,955 & 28.2 & $2,000^{\circ}$ & 14.3 & $124^{c}$ & 0.9 & 5,350 & 38.2 & 894 & 6.4 & 14,013 & 100 \\
\hline United States & 1,500 & 2.0 & 4,200 & 5.6 & 35,700 & 48.0 & 22,700 & 30.5 & 4,000 & 5.4 & 6,300 & 8.5 & 0 & 0.0 & 74,400 & 100 \\
\hline \multicolumn{17}{|c|}{$\begin{array}{l}\text { Notes: } \\
\text { - not available } \\
\text { 1. Data cover principal, but not all, organisations involved. } \\
\text { a. Ontario Hydro only. } \\
\text { b. Estimate. } \\
\text { c. Excluding staff in other organisations employed under contract. } \\
\text { Source: OECD }\end{array}$} \\
\hline
\end{tabular}


Figure IN NUCLEAR POWER-PLANT OPERATION AND MAINTENANCE SECTOR

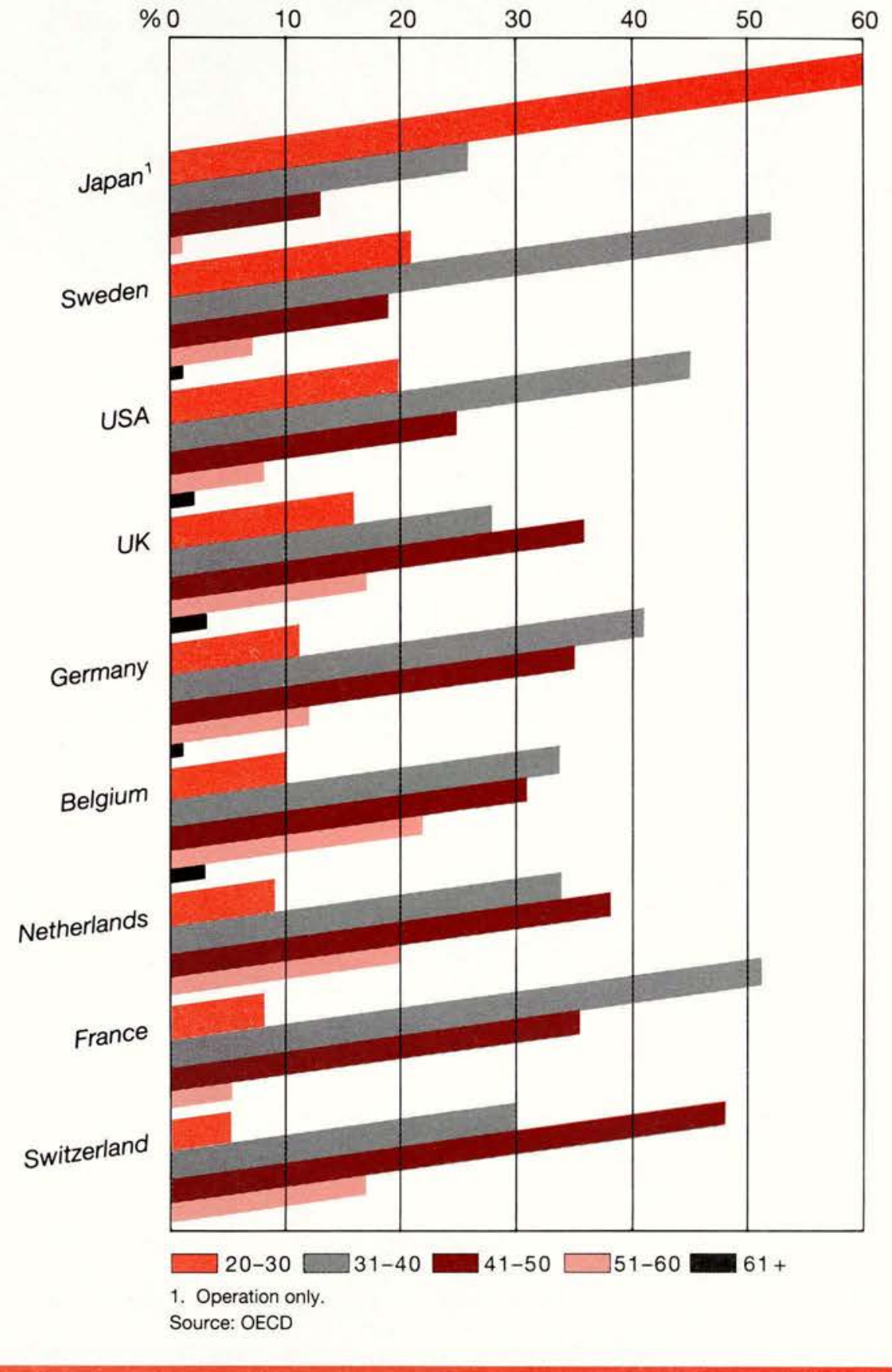

for electricity, and the co-operation of OECD member countries with central and eastern European countries and the states of the former Soviet Union for improving the management and safety of nuclear plants - all will necessitate the maintenance of a strong core of qualified nuclear engineers and scientists. In particular, highly trained specialists are required in universities to meet future demand for the education of students who will go on to nuclear-related design, applications and teaching.

Reliance by governments and industries on market forces to rectify imbalances in manpower supply and demand may be an inadequate response: the time-scale may be too large and too difficult to predict to be sure that the labour demands of the nuclear industry can be met. Anticipating changes in supply and demand and taking appro- priate timely measures might well prove a sounder approach.

Several countries have therefore already initiated actions to support nuclear R\&D and education:

- government funding of research and development programmes at universities, institutes of technical education, research establishments and in industry

- funding by both government and the nuclear industry of students and lecturers in universities and specialised summer courses

- close co-operation between nuclear utilities, research centres and universities in carrying out R\&D projects, student and personnel training and exchange, and so on

- support of relevant educational activities of public research institutions.

Additionally, continuous monitoring of the supply of qualified manpower should be undertaken to help maintain a clear picture of the status quo and of the likely evolution of demand.

\section{볼}

The demand for expert manpower in OECD countries will continue for decades, whatever strategy each country adopts for the generation of nuclear power. In view of the aging of the work force that is already active in the industry and the difficulties foreseen in the further supply of qualified manpower, it is heartening that steps are being taken to overcome these problems. A careful watch should be maintained to see that the policy measures already taken are efficient, and are reinforced if necessary. Furthermore, OECD countries and organisations active in nuclear energy should continue to investigate new measures that will help ensure an adequate supply of manpower for the future.

\section{OECD Bibliography}

- Qualified Manpower for the Nuclear Industry: An Assessment of Demand and Supply, forthcoming 1993

- OECD Nuclear Energy Data, 1992. 


\section{Technological Spin-offs from Nuclear Energy}

The beginnings of the nuclear-energy industry required a huge investment in research. It has, over the years, proved a prime source of industrial innovation. ${ }^{1}$

\section{Pierre Girouard}

$\mathbf{N}$ uclear energy has been used to generate electricity since the 1950s. Early developments began with the construction of low-power research or demonstration reactors, mainly to try to understand basic physical phenomena, to generate data, test nuclear fuels and reactor components, and to produce radioisotopes for further research.

The next phase, in the 1960s and early ' 70 s, consisted of largerscale production of nuclear fuels and the construction of the first (small) nuclear-power reactors. The capacity for production of nuclear power grew from zero in 1950 to 326 GigaWatt-electrical, world-wide, in 1991. (To give an idea of the magnitude of this amount, OECD Europe had in 1990 a total electric capacity from all sources of 434 GigaWatt-electrical; nuclear sources provided about $20 \%$ of this figure.) Simultaneously, regulatory bodies were being created in many countries, producing a large set of regulations and codes of practice.

Every stage in this setting-up, from scratch, of a new sector of industry and the numerous ramifications of its service industries and regulations called for the support of an enormous amount of research and development (R\&D). It was required in a broad variety of activities: basic $R \& D$ on nuclear fission and ways of controlling it; structural materials and equipment to contain nuclear

Pierre Girouard is a nuclear engineer in the Nuclear Development Division of the OECD Nuclear Energy Agency. materials; the design and construction of reactors, and their safe operation; probabilistic analysis techniques; the isotopic enrichment of materials to be used in fission; the design and fabrication of nuclear fuel; the reprocessing of spent

Solar-energy technology has benefited from the 'spin-offs' of research in nuclear energy.

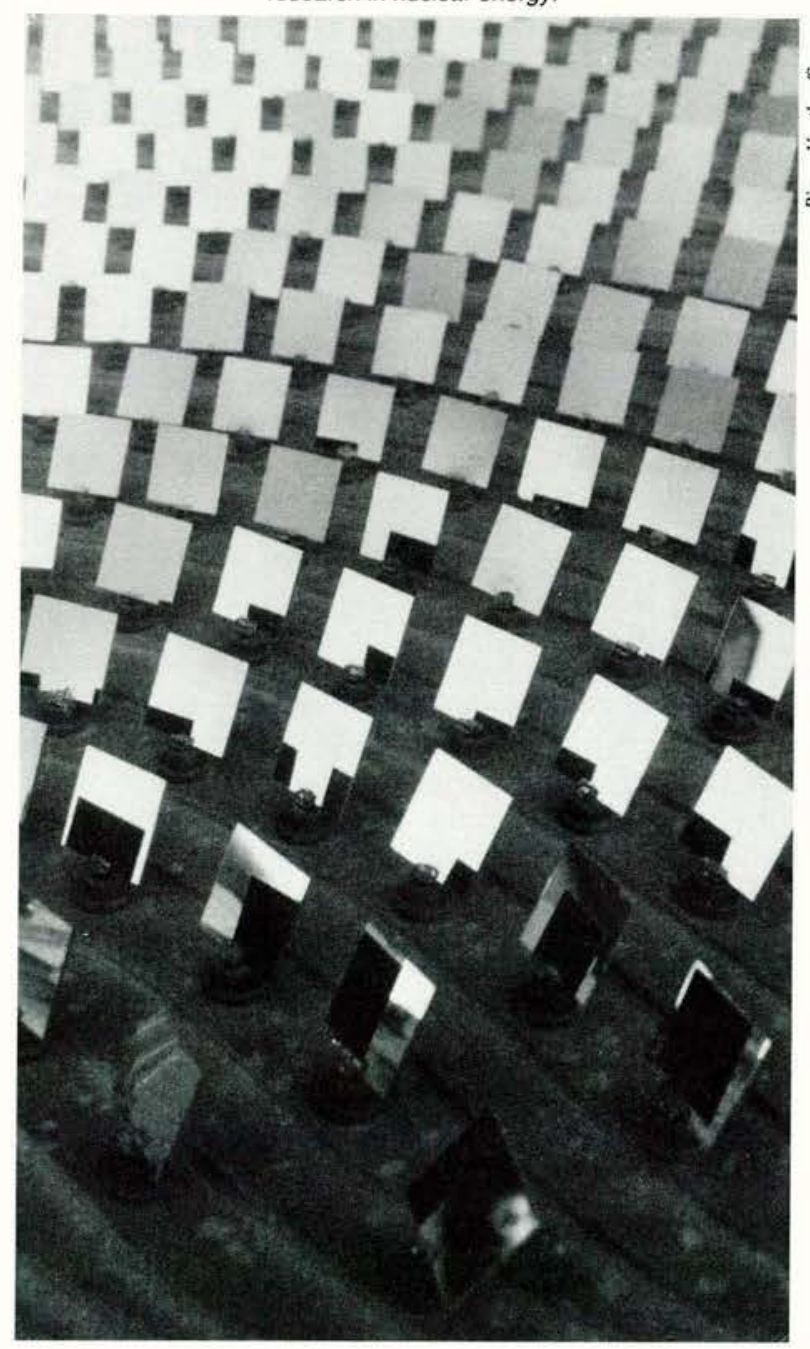

fuel and recycling of recovered plutonium; the handling of wastes, their safe management and disposal; mathematical modelling of reactor core operation under special conditions and assessment of safety and/or residual risks; the development of electronics and instrumentation, and of major machinery, such as pumps.

\section{Spin-offs from R\&D}

Soon after R\&D programmes on nuclear energy began to yield results in terms of competitively priced electricity, several R\&D and industrial organisations recognised that the new skills and general expertise might also be exploited as 'spin-offs' in other sectors of science, technology and industry. And when, in the 1980s, the nuclear sector reached technical maturity, it started converting part of its R\&D and service potential towards these other objectives.

In an attempt to identify the main beneficiaries the OECD Nuclear Energy Agency (NEA) recently investigated the transfer of primarily nuclear technology to nonnuclear applications - the spinoffs. To avoid casting the net too wide, the study excluded food irradiation and medical uses as well as the production of isotopes, nuclear applications which are well known and have developed into industries of their own.

Based on responses to a questionnaire, the NEA study compiled

1.Spin-off Technologies Developed through Nuclear Activities, NEANOECD Publications, Paris, forthcoming 1993. 
a list of spin-offs, classifying them according to the technologies involved, the methods of transfer, and the industries to which the technology was transferred.

\section{Who Benefits?}

Of the near-300 cases submitted, 126 were generated by government laboratories, 107 were examples generated by private enterprises, three from mixed (part-governmental, part-private) enterprises. Most of the spin-offs benefitted private enterprise (two-thirds of the cases) or mixed enterprises (most of the rest). Although only half of the cases showed the source of technology to be a private company, the main beneficiary of the transfer itself was unquestionably private enterprise.

There are several basic nuclear technologies involved:

- the testing and inspection of materials and products

- the fabrication of materials (catalysts, ceramics, alloys, and so on)

- engineering and design

- instrumentation and control, cables, electric and electronic technology

- environmental technology

- manufacturing and mechanical applications

- quality assurance and safety

- robotics, handling and transport

- software

- business and project management techniques

- simulators and training.

These technologies are transferred by a variety of means, chief among them licensing, co-operation agreements and joint ventures, outright sale, R\&D contracts, publications and conferences, consulting, the movement of personnel, and the internal transfer of information within the company or institute concerned.

Nuclear spin-offs have a wide range of applications, although the main beneficiaries are sister industries in the power sector, not least fossil-fuel plants. The largest non-power industries to benefit are petroleum/gas and chemicals; the others include most prominently: engineering; electricity, gas and hot water; oil and gas extraction; the manufacture of base metals, metal products, machinery, precision and electrical equipment, rubber and plastics; sewage and waste treatment; transport; radio and TV; and construction.

There are also environmental benefits. Radioactive waste management deals with long-lived radioisotopes that require specific conditioning processes and systems for geologic disposal. Experience gained in handling radioactive wastes is being considered for the management of non-radioactive toxic wastes such as the heavy metals discharged by conventional industry (such as chemicals).

'Probabilistic Safety Assessment', likewise, has become part of the process of evaluation of safety and risks at nuclear facilities. The methodology, which originated also in the aeronautical industry, can be directly transferred to activities in the chemical industry or others where there are risks of large accidents.

Corrosion of the cooling circuit is an important factor in determining the life of nuclear power plants; and experience in dealing with corrosion is directly transferrable to numerous other industrial sectors (for example, non-nuclear power or, again, chemicals). Since research in this area is not necessarily covered by patent rights or other forms of rewards, it has not generally produced as many spin-offs as other activities.

Many laboratories, both public and private, have attributed growing importance to spin-offs and adapted their structures and programmes, thus facilitating the generation and exploitation of secondary technology. That may involve a change of institutional 'culture' and statutes, often in line with government objectives to transform the results of high-tech R\&D into useful products and services.

Co-operation agreements involving licensing are a popular means of technology transfer as they can be tailored to the requirements of the market. Contacts and exchanges of personnel also seem to offer a high probability of success because of the direct personal involvement.

Naturally, individual cases will require careful consideration in choosing the way best adapted to generate spin-offs. Institute- or country-specific arrangements have been reported for technology transfer and generation of spin-offs, some involving both informal and institutional benefits, not least for employees. There are examples in the 'essaimage' in France (guaranteed re-employment, in case of failure, for those who attempt to start up their own businesses), royalty distributions to employees, co-operative research and development agreements, and so on.

\section{Steering Secondary Benefits}

To be successful, an active spin-off policy, whether governmental or institutional, should take into account the following requirements. First, the production of spin-offs should not interfere with the central activities of the establishment. Second, a thorough understanding of the target sector and the way it works is of the highest importance, since it allows an insight into what the industry requires, and provides the base from which innovation and relevant ideas can stem. Third, although personal contacts are important, more structured market research may also be necessary, to establish, for example, the best means of exploiting a particular invention. Fourth, careful timing in approaching a potential partner is required; partners should be involved as early as possible to ensure that the development proceeds along industrially viable lines. And last, the application should be defined as tightly as possible so that, while the licensee can capitalise on the invention in his own business activities, the inventor retains the maximum freedom to exploit it in other sectors.

Business development and commercial activity in general bring in additional income which can enable institutions, at least partially, to offset reduced funding from governments, to avoid reducing teams of researchers below the 


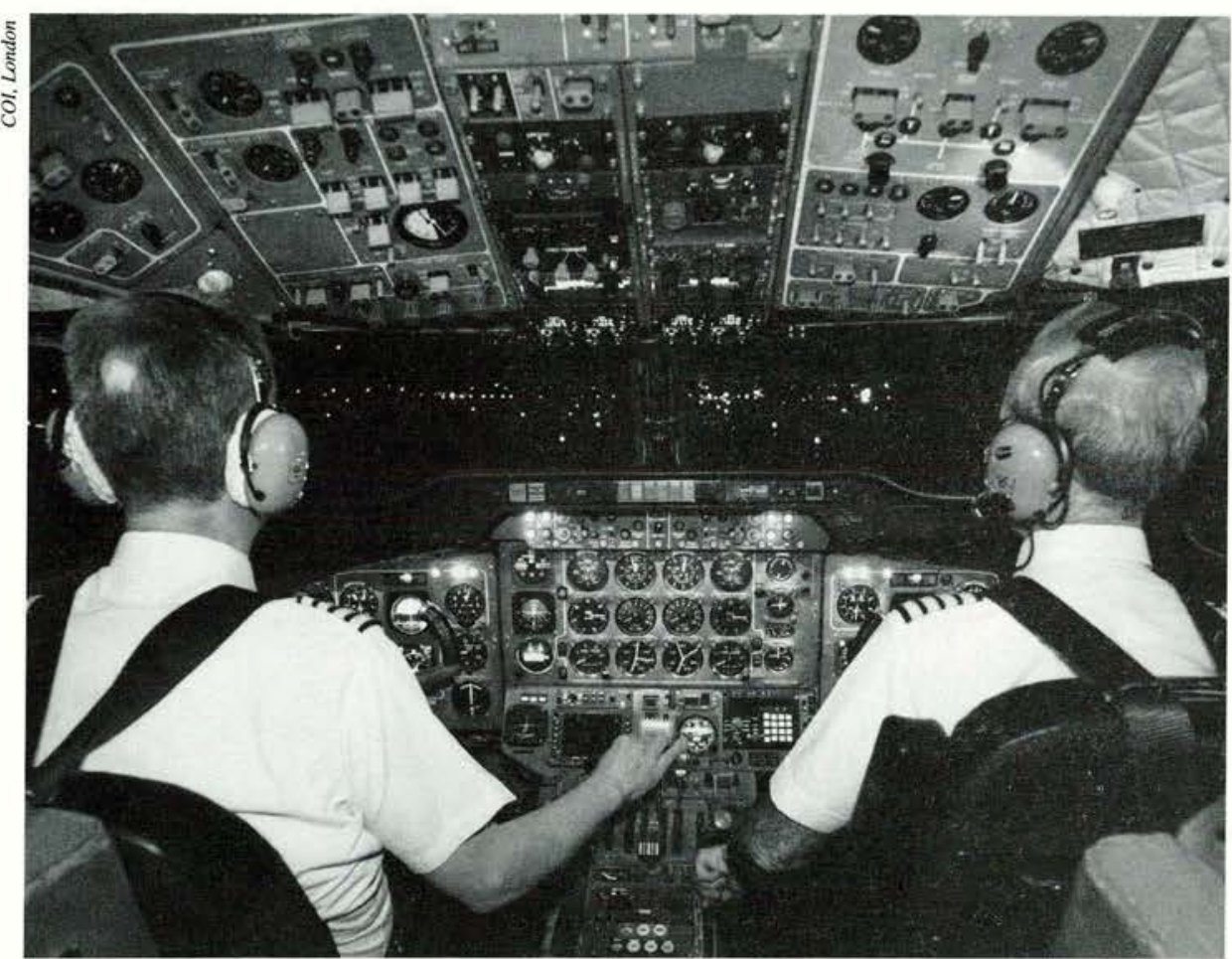

capacity required for effective work, and, in part, to keep equipment and facilities at a 'state-of-the-art' standard. Responding to business interests in the market provides a useful commercial discipline for research laboratories. It also leads to enhanced career opportunities for the researcher who champions successful technologies, processes or products.

\section{Diversification of R\&D}

Originally, nuclear development was mainly 'technology push' - planners were concerned about future availability of fossil-fuel resources and decided to develop ('push') the nuclear option. As soon as some of these activities reached industrial maturity, programmes of national laboratories gradually shifted towards 'market pull', although with exceptions in, for example, radiation protection and the management of nuclear waste. Major nuclear programmes - that for fast-breeder reactors, say - were much reduced in a number of countries (France, the United States and others); a few simply discontinued some activities, whereas others scaled back their individual efforts through well-organised international co-operation.
Another beneficiary of nuclear technology: 'intelligent' control systems in aircraft.

This reduction of demand on established capacities, together with the awareness of a high degree of 'excellence' in the laboratories, contributed to the tendency towards diversification. Available resources were turned to developing other markets and adapting existing products to those markets. One example of this trend is the development of fabrication technology for new types of ceramics or superconductors by teams formerly employed in the development of nuclear fuel.

This diversification was driven partly by scientists and laboratory managers and partly by owners or governmental authorities who intended to use the existing R\&D capacity for other objectives. The next step was a more radical change of the corporate culture of companies which devoted effort to marketing and to adapting programmes to market demand. One of the more successful examples of a change of culture has been AEA Technology in the United Kingdom which became a market-oriented company, essentially converting itself from a nuclear-oriented, government-owned company to a 'technology company' alert to market opportunities.

In the first steps of diversification, successful spin-offs were rather occasional, almost accidental. The chances of success have increased with the growing adaptation of programmes to existing or potential demand. That may generate problems of availability or preservation of essential skills deemed to be of 'public interest', as, for example, support of nuclear safety authorities. It is also true that the public interest, represented by government, constitutes a 'pulling market'.

\section{a}

Since spin-offs from the nuclear industry are, by definition, a by-product, they must be considered as a long-term process for the transfer of knowledge and not as a money-raising palliative to replace adequate funding of the requisite $R \& D$. But they can help to maximise the return on accumulated investment in knowledge. In some countries structured initiatives to promote the diffusion of spin-offs have been very recent (even within the last three years), and it is therefore too early to evaluate fully the extent of their success.

Individual countries and institutions can have particular interests, particular strong points, particular demands. If these are borne in mind, a more systematic approach to the promotion of nuclear spin-offs could bring substantial additional benefits.

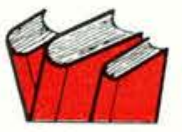

OECD Bibliography

- Spin-off Technologies Developed through Nuclear Activities, NEA OECD, forthcoming 1993

- Broad Economic Impact of Nuclear Power, NEANOECD, 1992

- OECD Science and Technology Indicators Report, No. 3: R\&D, Production and Diffusion of Technology, 1989

- The Changing Role of Govemment Research Laboratories, 1989. 


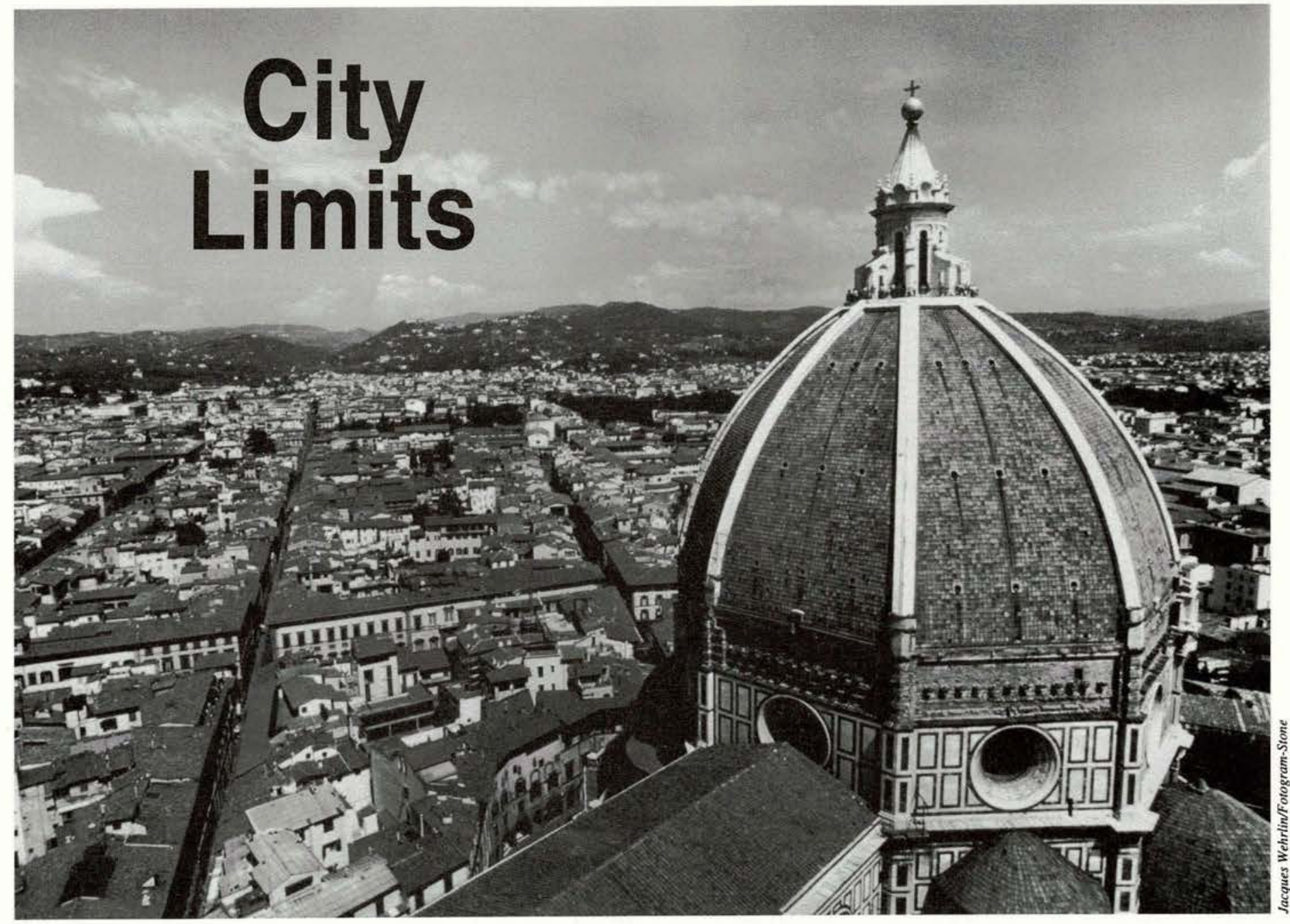

\section{The city-planner is faced with a dilemma: urban problems that seem to call for intervention - and the impossibility of knowing what that intervention might produce. But there is a middle way which allows the combination of economic rationalism and social responsibility. ${ }^{1}$}

\section{Rémy Prud'homme}

$n$ the OECD countries, where $80 \%$ of the population live in cities, the quality of life depends first and foremost on the quality of cities. It is therefore quite natural that politics and politicians should be involved with cities and raise questions as to how they should be designed or improved. This has been happening for some four thousand years. It is not by chance that the word politics itself comes from the Greek root polis, meaning city.

But the ways in which cities are perceived, and urban policies them-

1. This article is based on a presentation to the International Conference on the Economic, Social and Environmental Problems of Cities, held at the OECD on 18-20 November 1992; a publication based on the Conference is in preparation. See Christopher Brooks, 'Rethinking the City', The OECD Observer, No. 178 , October/November 1992 selves, change over time. In the 19 th century, and until the middle of the 20th, in many European countries, and in France in particular, the concept of 'the city' was a value held by the political left; for such people as Victor Hugo or Jean Jaurès it was a symbol of science, freedom and progress. The political right was, by contrast, suspicious of urban life, which it saw as a source of corruption, anarchy and decadence 'the burial ground of races', as Pétain put it. In more recent decades these views have been almost completely reversed. The 'right' has discovered the city to be productive and efficient. The 'left' has become sensitive to the social

Rémy Prud'homme was formerly Deputy Director of the Environment Directorate of the OECD and is now Professor of Economics at the University of Paris XII. and environmental costs of urban agglomeration and is now in its turn suspicious of the city. The ultimate, grotesque expression of this suspicion was perhaps when the Khmers Rouges took control of Phnom Penh and emptied it of its inhabitants. This complete turnaround probably mirrors the dissolution of the concept of the political right and left as such; but it may also reflect the paradox facing government when it attempts to intervene in urban planning.

\section{The Necessity of Intervention}

It is easy to show why political intervention in urban life is unavoidable. First, history demonstrates that cities 
have been shaped by politicians. From Alexandria to Brasilia, via Washington and St Petersburg, many cities have been the result of political will, the manifestation of a political project. And cities born spontaneously, from the play of market forces, also bear in their flesh the marks of kings, presidents or other leaders. The 19th century presents an interesting paradox from this standpoint. Although it was the age of triumphant liberalism, with a non-interventionist state, political activism was also marked during this period in the building of underground railways, sewers, bridges and so on. The burden of taxation was only a fifth of what it is today, and local authorities had less power than they do now; nonetheless, money was found to build up an urban infrastructure which has survived to the present day. And in cities as different as New York, London and Paris, which owed their growth to capitalism and speculation on landvalues, political intervention permitted the establishment of parks and maintenance of open spaces.

The economic theory of public goods and the presence of externalities both suggest that there is a role for state intervention in the city, that the invisible

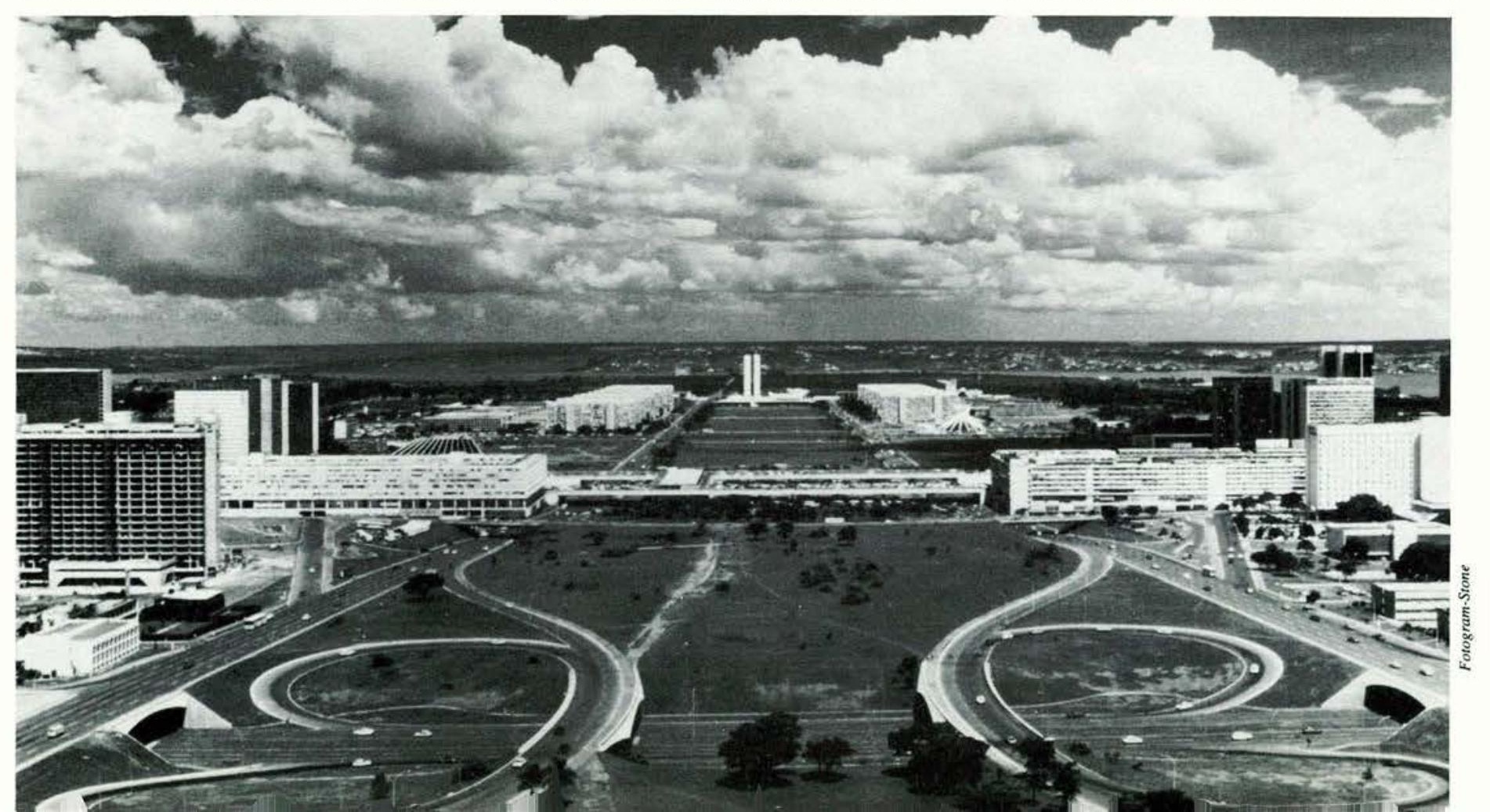

hand of the market might not produce the housing, parks, sewers and road systems that cities require and that it therefore has to be guided by the very visible hand of political authority. And indeed, in all sorts of ways and in all countries there are policies in place that modify or constrain the form that cities take. The ministers responsible for cities are often, without their wishing it, and sometimes without their even knowing it, ministers of finance or transport. To offer a classic illustration, taxation that favours new building helps promote urban spread, whereas taxation that encourages the rehabilitation of existing housing will strengthen town centres. Likewise, the increasing numbers of high-speed trains also favour the city centres, whereas increasing air traffic tends to favour the outlying suburbs.

The question is therefore not one of whether intervention to affect the shape of cities is desirable. It is inevitable. The question is rather one of whether it should be deliberate or involuntary, direct or indirect, what should be its objectives,

Brasilia is one of the many cities, in all parts of the globe, fashioned directly by political decision. and what tools should it use. Here is the crux of the problem, since closer inspection suggests that such necessary intervention is an impossibility.

\section{The Inevitability of Ignorance}

Intervention in the shaping of cities appears impossible, or at least very difficult, for at least three reasons. The first is that there is no agreement as to what types of cities are desirable. Arguments can be found in favour of the large city, but others that are equally convincing supportsmallones; some favour polarised cities, others decentralised ones, functional cities or mixed. The reason is undoubtedly that cities are judged, and have to be judged, from four or five different viewpoints. The form of urban development that is good for efficient production (assuming one knows which it is) will probably not be good for the quality of the environment, or for the healthy growth of social relationships. Dream solutions, utopias, visions of what cities might be are plentiful; urban planners produce them daily. But utopias stand up badly to analysis and to the passage of time. The functionalism of architects like 


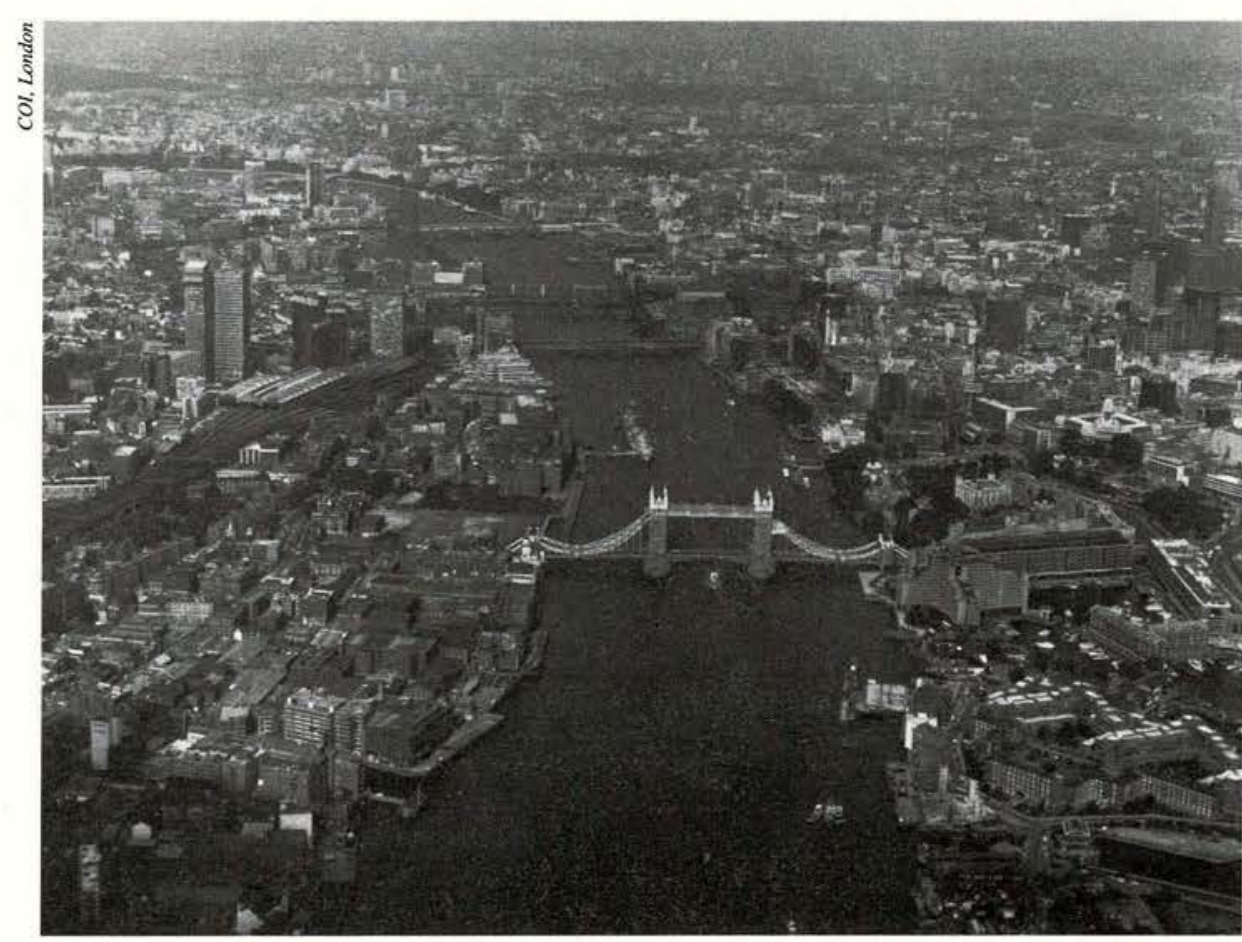

Le Corbusier, much admired yesterday (or the day before yesterday), is now widely condemned. Utopias are perhaps the essence of political life; it could be said (after Shakespeare) that our cities, like our lives, are the stuff that dreams are made of. But dreams are not enough to support an investment programme.

The second reason for the impossibility of urban intervention is that there is no agreement on how to achieve objectives. Indeed, not only is there no agreement on the destination; there is none on how to get there, none on what plans to make, let alone on how to achieve them. The filing cabinets of urban-planning agencies across the globe are full of projects which have never been implemented. Intervention can take four possible forms: investment, restrictions, incentives or information. None of these is well suited to urban intervention. There are too many actors, circuits and externalities between the action and the objective. In an attempt to reduce travel, for example, a satellite town can be created, thus providing jobs nearer homes - and then it is found that many of the residents actually work in the city centre whereas many of the new jobs are filled by people from the centre, so that the journeys made, far from being reduced, are in the event longer than ever.

There is a third reason: in most OECD countries cities are no longer growing very much. The two sources of the increase in the urban population, in-

\section{One is therefore faced with a dilemma:}

Modern London has been formed by the agglomeration of a multitude of smaller communities.

on the one hand, political intervention to change the form of cities seems necessary, and on the other it seems impossible. How can the dilemma be resolved? By advocating or practising what might be called modest intervention.

\section{A Half-way House}

Modest intervention seeks the middle way between inadmissible passivity and unrealisable utopia. It is based on caution and, more particularly, on suspicion. Suspicion of uniformity, suspicion of the irreversible, suspicion of externalities, suspicion of ignorance. On this basis it is possible to outline a strategy for urban intervention.

The first element of such a strategy, based on the avoidance of uniformity, involves the encouraging of diversity. Since nobody knows which is the best shape a city should take - or, more precisely, since it is known that all urban forms have advantages and supporters - it is important not to rule out any of them. City dwellers ought to be able to choose between densely populated cities alongside extended ones, small towns alongside large ones, private alongside public transport, single-centre cities alongside multicentred ones, apartments alongside individual houses,

How much planning? Will modest intervention allow different elements of city life to evolve in harmony?

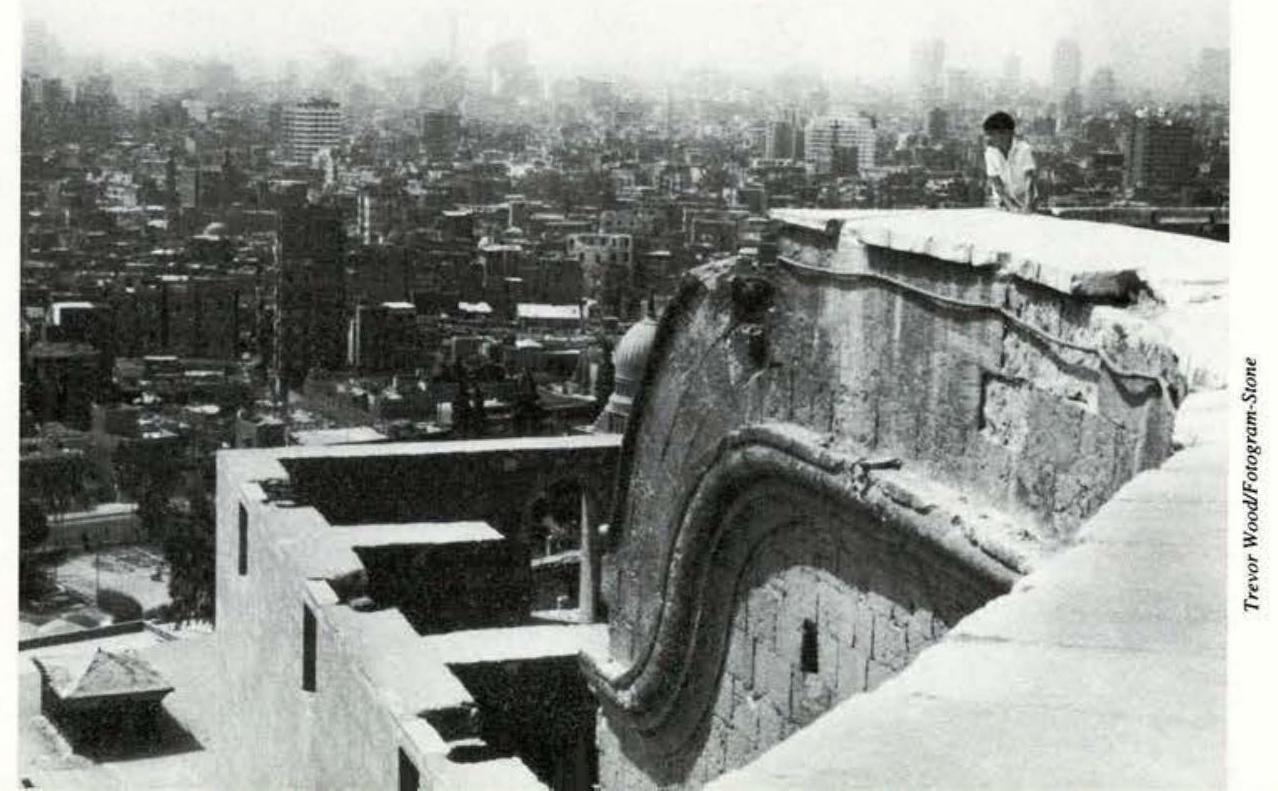






Functionalism joins other forms of utopian planning which have weathered badly.

restored city centres alongside modern suburbs. Diversity results from innovation, but innovation of this sort should be homeopathic rather than surgical. Experiments should be legion, and lead in all directions.

The second element of this modest strategy entails preserving the future or, to put it another way, combatting irreversibility. To preserve the future requires the protection of what exists at present, the conservation of urban forms, as with threatened species. The conservation movement, backed by the environmentalists, is now powerful enough to safeguard the essential. But preserving the future also means seeking solutions that can be adapted and adjusted. Rising incomes, faster technical progress, changing tastes and behaviour will tomorrow make both possible and desirable solutions that cannot even be imagined today. What is crucial is not to prohibit them. From this standpoint it can be salutory to read about the utopias, predictions and plans of the past like, for example, those produced at the end of the 19th century which took no account of the motor car and calculated in all seriousness the date by which the accumulation of droppings from the horses required for urban transport would make large cities inaccessible.

The third element involves correcting externalities. To escape from the dilemma of the impossible market and the impossibility of planning, the economist offers a solution. Planning should correct rather than replace the market; it should help it work better rather than take its place, through the internalising of externalities. It can involve taxing economic agents for behaviour which imposes the costs of their decisions on others, or subsidising behaviour which gives others the benefit of these decisions. Rather than seeking, for example, to define the exact place of cars in the city, they will simply be made to pay for the congestion and pollution they cause; each motorist, faced with the true cost, the cost to society as a whole, of his decision to use or not to use his car, will take the decision that both suits him best and also suits society as a whole. This kind of liberal intervention stresses the mechanism rather than the result, the process rather than the outcome, the route taken rather than the destination. It avoids having to take decisions aimed at a result, outcome or destination, and at the same time it modifies them in a socially desirable direction. It enables the structure of the cities to be adapted without having to know which structure is the right one. It is a modest but effective form of intervention which is coming to be used, and will be increasingly so.

$$
\text { 좀 줌 }
$$

This more modest approach to town planning will require more analytical work. Just as research is the key to success in the chemical or computer industry, so it is also the key to success in urban policy. Not enough is known about the workings of the urban system or systems, about the implications of the different forms of urbanisation, the mechanisms by which they are produced, and hence the objectives to be achieved or the kinds of intervention to be used. Comparative analysis is vital since investigation of a single country is often inadequate. The experience of intervention in different countries also has to be compared, and the reasons for success or failure understood. The OECD countries must exchange information about their urban policies more systematically, as they do in their environmental and fiscal work.

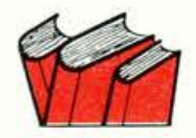

\section{OECD Bibliography}

- Christopher Brooks, 'Rethinking the City', The OECD Observer, No. 178, October/November 1992

- Ariel Alexandre, The Case for the Urban Environment', The OECD Observer, No. 175, AprilMay 1992 - Ariel Alexandre and Eric Oberkampf, 'Funding Urban Infrastructure', The OECD Observer, No. 172, October/ November 1991.

- Managing and Financing Urban Infrastructure, 1991

- Environmental Policies for Cities in the 1990s, 1990 


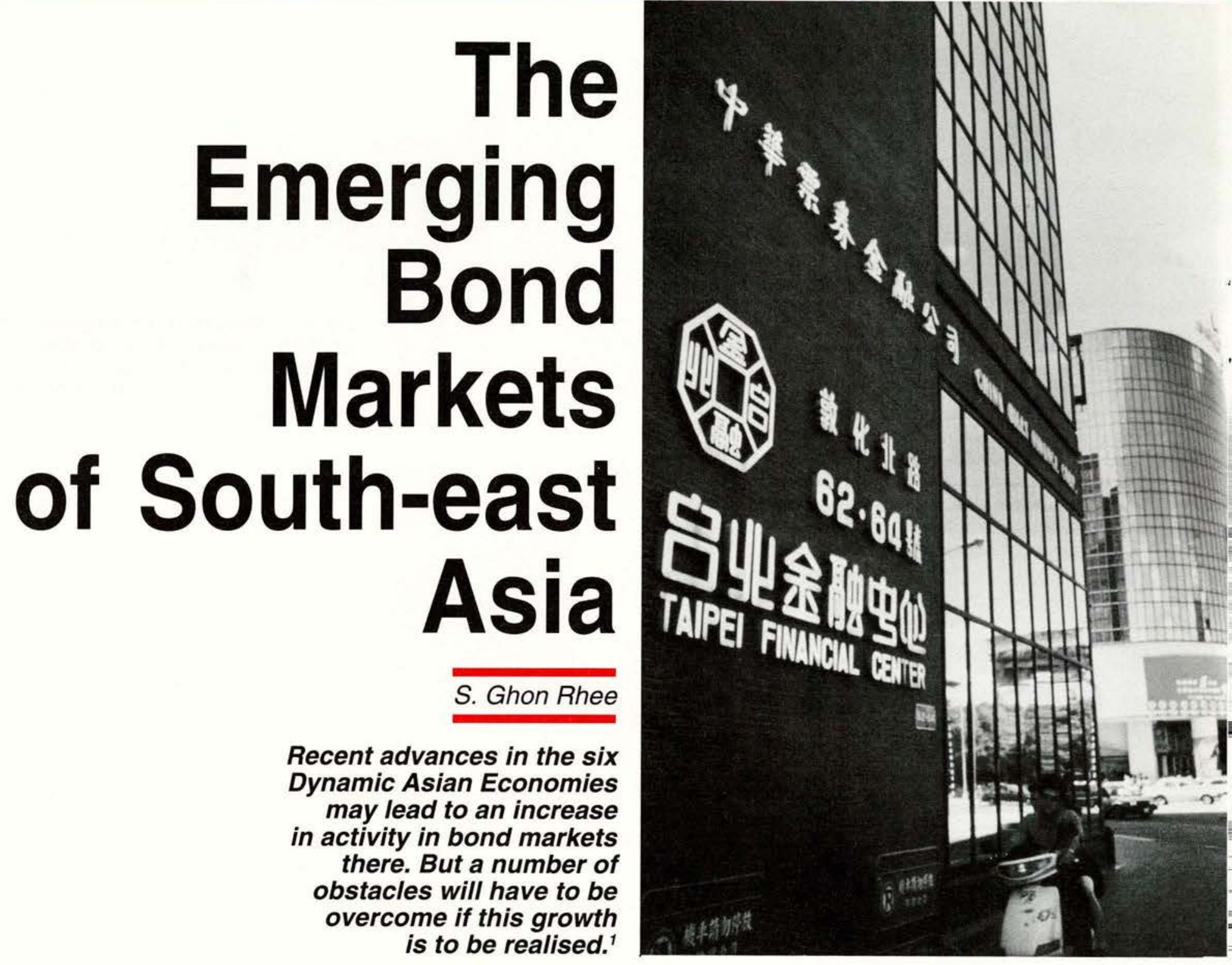

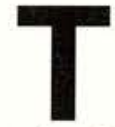

he past decade has seen a rapid expansion of securities markets outside the group of OECD countries. Prominent among them have been the Dynamic Asian Economies (DAEs) Hong Kong, Malaysia, Singapore, South Korea, Taiwan and Thailand. Until now, this vibrant development has largely been concentrated in their stock markets; bond markets in most of the DAEs have remained relatively small or inactive, or both. The volume of bonds outstanding is particularly small in Hong Kong, Singapore, Taiwan and Thailand, and somewhat larger in Malaysia and Korea (Table 1). But the prospects for trading in fixed-income securities are brightening, now that promoting the evolution of bond markets has becomea goal of government policy in all the DAEs.
Securities markets can be broken down into primary markets (where the securities are issued and bought by individual investors or institutions) and secondary markets (where securities are traded from one holder to the next). Primary-market activities in the last five years are summarised in Table 2; the volume of bond issues in most DAEs, with the exception of Korea and Malaysia, has been almost insignificant. But that may change in the near future. Many countries, especially Malaysia, Korea and Thailand, have reduced borrowing from foreign sources and have instead expanded domestic sources of capital.

S. Ghon Rhee is Professor of Finance and Director of the Pacific-Basin Capital Markets Research Center at the University of Rhode Island (United States). He recently worked as Senior Consultant to the OECD Committee on Financial Markets.
Hong Kong and Taiwan have announced ambitious infrastructure projects, which include new or improved airports, highway systems, rail-links and harbour development.

It is expected that substantial portions of the funds required for domestic expansion will be financed by new issues of government debt. Inevitably, this move will expand the aggregate value of outstanding government-debt securities. Nevertheless, even if the government issues large volumes of bonds, this does not necessarily lead to lively trading in such bonds. In other words, higher volumes of government debt do not necessarily promote market liquidity

\footnotetext{
1. Emerging Bond Markets in the Dynamic Asian Economies, OECD Publications, Paris, forthcoming 1993.
} 


\begin{tabular}{|c|c|c|c|c|c|c|}
\hline \multicolumn{7}{|c|}{$\begin{array}{l}\text { Table } 1 \\
\text { SIZE OF DAE CAPITAL MARKETS } \\
\% \text { of GNP }\end{array}$} \\
\hline & Hong Kong' & Korea & Malaysia & Singapore 1 & Taiwan & Thailand \\
\hline Equity Market & 149.0 & 36.0 & 130.0 & 142.0 & 66.0 & 43.0 \\
\hline Money Market ${ }^{2}$ & $8.0^{\mathrm{a}}$ & 28.0 & 23.0 & $5.0^{b}$ & 16.0 & .. \\
\hline Govemment Bond Market & 0.1 & 16.0 & 53.0 & 14.0 & 7.0 & 7.0 \\
\hline Corporate Bond Market and others & 6.0 & 14.0 & 6.0 & 3.0 & 2.0 & 0.2 \\
\hline \multicolumn{7}{|c|}{$\begin{array}{l}\text { Notes: } \\
\because \text { not available } \\
\text { 1. \% of GDP. } \\
\text { 2. Based on the outstanding amount of money-market instruments; excludes trading volume in interbank market. } \\
\text { a. Bankers' Acceptances excluded. } \\
\text { b. Bills of exchange and certificates of deposit excluded. } \\
\text { Source: OECD }\end{array}$} \\
\hline
\end{tabular}

(measured by the share of outstanding bonds offered and demanded at any given point in time on the secondary market).

It is true that, in a number of DAEs (particularly Taiwan, Hong Kong and Singapore), the annual turnover of government bonds, as a percentage of market capitalisation, was very high (Table 3). But the opposite is true for Malaysia, Korea and Thailand. Thailand's annual turnover of government bonds, which is less than $1 \%$ of market



capitalisation, implies that virtually all of them are purchased on the primary market and then held until maturity (the date of redemption, when the loan is repaid; box, p. 21). In most cases, these holders are financial institutions, including the central bank. Secondary bond markets in these countries thus have yet to be fully developed.

Though there is minimal activity in the government-bond markets in the DAEs, there is even less in corporate bonds. The lack of supply and demand in the market for long-term corporate debt is a continuing concern of the six DAEs, with obvious implications for economic growth. In some DAEs, particularly Hong Kong, Taiwan and Thailand, corporations rarely use the bond market as a source of finance; instead, loans are usually borrowed from banks. It is often argued that corporate-bond trading receives a stimulus from an active government-bond market. That suggests that corporate-debt markets would indeed expand if the DAE governments developed long-term governmentsecurities markets.

In considering which obstacles should be removed to promote the development of bond markets, two immediate questions have to be answered. First, why are the DAE bond markets so small? And, second, why has the secondary market not developed, even in countries like Malaysia or Korea where the primary market is fairly large? One cannot provide a set of generalised conclusions because the situation is not identical in all six economies. Yet five possible explanations may be identified, which set the agenda for any DAE government that wishes to develop its bond market.

\section{Artificial Interest Rates}

First, a controlled or administered structure of interest rates is a critical impediment to the development of a fixed-income securities market. In Korea, Malaysia and Thailand, the effective yields on government bonds are kept low without reflecting conditions in the credit market. As a result, the governments of the three countries rely on financial institutions as captive demanders of government bonds when first issued. For example, the Bank of Korea (the central bank) issues bonds, labelled 'monetary stabilisation bonds', as part of its monetary policy. Financial institutions subscribe to these bonds, and hold them in order to meet the reserve and liquidity requirements imposed by the Bank of Korea.

Monetary stabilisation bonds do not enjoy much popularity among subscribers, since their yields in primary markets are too low - in the range of $5-10 \%$, which is comparable to the level of the (government-controlled) interest rates on savings accounts and time deposits. Interest rates on the free market are around $16-18 \%$. As a result, the prices of the bonds drop substantially to reflect free-market interest rates. Thus the holder can sell the bond on the secondary market only at a substantial loss or, alternatively, hold on to these securities until maturity. Financial debentures, issued in Korea by specialised banks that finance development, offer another example of a large discrepancy (around 5 percentage points) between controlled yields on the primary market and free-market ones on the secondary market.

This kind of discrepancy is not unique to Korea. Because of their uncompetitive yields, Malaysian government securities are usually held by domestic financial institutions, which are legally required 
to do so. The Employees' Provident Fund is the largest holder of Malaysian government securities, with about $62 \%$ of the outstanding issues. Commercial banks hold about $25 \%$, and other financial institutions the remainder. In Thailand, commercial banks used to be required to hold government and governmentguaranteed bonds to amounts equal to at least $16 \%$ of their total funds. This requirement was known as a 'branchopening requirement' or ' $16 \%$ condition'. By February 1992 that figure had been gradually lowered to $7 \%$. When demand for government securities increased as deposits grew, some commercial banks stopped quoting the selling price of government bonds, and the spread between bid and asked prices became so large that secondary-market activity died away entirely.

Largely because of the direct or indirect control of interest rates, primary-market activities must rely on captive financial institutions, which rarely sell their bonds on the secondary market. The resulting lack of supply means that the secondary market for government bonds cannot function. The extent to which the secondary market is held hostage by controlled or administered interest rates is shown by the experience in Japan. In 1977 the Japanese government stopped relying on the captive financial institutions and began offering new issues of government securities in the open market. It was not until this reform took effect that the primary and secondary bond markets in Japan came to life. And indeed, the unusually high turnover ratios (that is, turnover divided by market capitalisation) observed in Hong Kong, Singapore and Taiwan may well be attributed to the fact that interest rates on government bonds there are determined by market forces.

\section{Bank Domination}

Most lending to the private sector in the DAEs takes the form of (short-term) bank credit; only a small part is done by issuing bonds. This dominance of commercial banks over the securities markets has long been a feature of the six DAEs. The magnitude of bank assets has consistently been around three times larger than the capitalisation of the equity markets; this has been found to be true in, for example, Korea, Taiwan and Thailand. Business firms in the region usually rely on short-term borrowing from various financial intermediaries as their major source of finance.

Indeed, commercial banks encourage private corporations to borrow on a shortterm basis rather than to lose them to the securities markets. In the majority of the DAEs, issues of corporate debt are usually required either to be covered by collateral or guaranteed by a thirdparty financial institution. In Korea, for instance, about $90 \%$ of corporate bonds are secured in this way. It is not unlikely that the imposition of such requirements can be ascribed, in part at least, to a strong lobbying effort from the banking sector, aimed at protecting its competitive advantage over the securities markets. In Japan commercial banks strongly resisted the issuance of unsecured debt by business corporations as late as 1979 .

\section{Shortfall in Securities}

A third reason for the under-development of the fixed income securities markets in the six DAEs is the limited supply of viable securities. An important cause of this shortfall can be found in statutory restrictions. The Company Law of Taiwan stipulates that the total amount of corporate bonds cannot exceed the net worth of the company. Similar legal restrictions are imposed in Korea, Malaysia and Thailand. As recently as

\begin{tabular}{|c|c|c|c|c|c|}
\hline \multicolumn{6}{|c|}{$\begin{array}{l}\text { Table } 2 \\
\text { PRIMARY MARKET ACTIVITIES IN DAES } \\
\text { US\$ billion }\end{array}$} \\
\hline & 1987 & 1988 & 1989 & 1990 & 1991 \\
\hline $\begin{array}{l}\text { Hong Kong } \\
\text { Government bonds } \\
\text { Corporate bonds } \\
\text { Total }\end{array}$ & $\begin{array}{r}- \\
0.27 \\
0.27\end{array}$ & $\begin{array}{l}-\overline{-} \\
0.15\end{array}$ & $\begin{array}{l}-\overline{-} \\
0.15\end{array}$ & $\begin{array}{l}0.10 \\
0.10\end{array}$ & $\begin{array}{l}0.08 \\
0.09 \\
0.17\end{array}$ \\
\hline $\begin{array}{l}\text { Korea } \\
\text { Government bonds } \\
\text { Financial debentures } \\
\text { Corporate bonds } \\
\text { Total }\end{array}$ & $\begin{array}{r}16.36 \\
1.65 \\
4.03 \\
22.04\end{array}$ & $\begin{array}{r}30.05 \\
2.60 \\
6.20 \\
38.85\end{array}$ & $\begin{array}{r}36.59 \\
2.86 \\
10.24 \\
49.69\end{array}$ & $\begin{array}{r}38.08 \\
5.95 \\
15.49 \\
59.52\end{array}$ & $\begin{array}{l}37.09 \\
10.09 \\
16.79 \\
63.97\end{array}$ \\
\hline $\begin{array}{l}\text { Malaysia } \\
\text { Government securities } \\
\text { Corporate debt } \\
\text { Cagamas bonds } \\
\text { Total }\end{array}$ & $\begin{array}{l}3.43 \\
0.07 \\
0.56 \\
4.06\end{array}$ & $\begin{array}{l}2.74 \\
0.47 \\
0.44 \\
3.65\end{array}$ & $\begin{array}{l}1.84 \\
0.60 \\
0.46 \\
2.90\end{array}$ & $\begin{array}{l}1.91 \\
0.64 \\
0.15 \\
2.70\end{array}$ & $\begin{array}{r}1.29 \\
0.77 \\
\cdots \\
2.06\end{array}$ \\
\hline $\begin{array}{l}\text { Singapore } \\
\text { Government securities } \\
\text { Corporate debt } \\
\text { Total }\end{array}$ & $\begin{array}{r}15.16 \\
1.38 \\
16.54 \\
\end{array}$ & $\begin{array}{l}1.87 \\
0.95 \\
2.82\end{array}$ & $\begin{array}{l}2.30 \\
1.19 \\
3.49 \\
\end{array}$ & $\begin{array}{l}1.06 \\
0.94 \\
2.00\end{array}$ & $\begin{array}{l}1.41 \\
1.04 \\
2.45 \\
\end{array}$ \\
\hline $\begin{array}{l}\text { Taiwan } \\
\text { Government bonds } \\
\text { Corporate bonds } \\
\text { Financial debentures } \\
\text { Total }\end{array}$ & $\begin{array}{r}1.936 \\
0.414 \\
. . \\
2.350\end{array}$ & $\begin{array}{r}2.643 \\
0.337 \\
\quad . . \\
2.980\end{array}$ & $\begin{array}{r}2.067 \\
0.126 \\
\ddot{2} \\
2.193\end{array}$ & $\begin{array}{r}0.454 \\
0.601 \\
\because . \\
1.055\end{array}$ & $\begin{array}{l}0.081 \\
0.008 \\
0.006 \\
0.089\end{array}$ \\
\hline $\begin{array}{l}\text { Thailand } \\
\text { Government bonds } \\
\text { State enterprise bonds } \\
\text { Corporate debentures } \\
\text { Total }\end{array}$ & $\begin{array}{l}1.153 \\
0.065 \\
0.089 \\
1.307\end{array}$ & $\begin{array}{l}0.809 \\
0.086 \\
0.126 \\
1.021\end{array}$ & $\begin{array}{l}0.639 \\
0.059 \\
0.169 \\
0.866\end{array}$ & $\begin{array}{l}0.267 \\
0.264 \\
0.154 \\
0.684\end{array}$ & $\begin{array}{r}\ldots \\
1.313 \\
0.261 \\
\ldots\end{array}$ \\
\hline $\begin{array}{l}- \text { none } \\
\text {. not available } \\
\text { Source: OECD }\end{array}$ & & & & & \\
\hline
\end{tabular}




\section{HOW A BOND MARKET WORKS}

A security is a document which provides evidence of creditorship or ownership. Creditorship securities include a wide range of debt instruments issued by the government, various government agencies, banks, multilateral development institutions, and business firms.

Most debt securities are fixed-income securities, which offer the holder an income ('interest') at a stated interest rate ('coupon rate'); floating-rate notes, for which the coupon rates vary at a given percentage above prevailing benchmark interest rates, are an exception. The four largest issuers of debt securities are business corporations, municipal governments, and central government and its agencies. Debt securities can be classified into money-market instruments with short-term maturities (redemption periods) of less than one year and long-term bonds with maturities longer than one year. Important money-market instruments are Treasury bills (issued by the government), commercial papers (issued mostly by business corporations) and certificates of deposit (issued by deposit-taking institutions). Long-term bonds include Treasury notes, Treasury bonds (both issued by the government), and corporate bonds. Depending on whether they are secured or unsecured, corporate bonds are classified into

mid-1992 the issuance of corporate debt by private enterprises was not permitted in Thailand unless they qualified as public companies authorised by the Stock Exchange of Thailand.

In Malaysia new bond issues must be approved by the Bank Negara Malaysia (the central bank) and the Capital Issues Committee. The borrower issuing the bonds must submit a profit forecast at the time when the issue is checked for approval and is penalised if, later on, profits are at least $10 \%$ below this forecast. According to the Bank Negara Malaysia's Guidelines on the Issue of Private Debt Securities, the minimum size of an issue must be $M \$ 50$ million (US\$18.36 million), which should be at least twice as large as net worth. This restriction is bound to keep smaller companies out of the market for corporate debt, even if they are credit-worthy. Because of these limitations, there is a lack of good-quality suppliers of private debt securities.

In a well-structured bond-market and with the proper infrastructure-adequate mortgage bonds and debenture bonds. or simply debentures. Mortgage bonds are backed by the pledge of specific property as security, whereas debentures are unsecured by real property.

A $\$ 1,000$ bond with a coupon rate of $6 \%$ offers the holder annual interest payments of $\$ 60$. The price against which he can trade the bond is not always equal to the face value of $\$ 1,000$, but varies with the general interest rate on the market: when interest rates go up, bond prices go down, and vice versa. If the market rate is $8 \%$, he could sell his bond only at a price of around $6 / 8 \times \$ 1,000=\$ 750$. The price is then $75 \%$ of the face value. This will ensure the buyer that he receives the prevailing market rate for his investment, namely a yield of $8 \%(\$ 60 / \$ 750)$ In the event, the price is also determined by other factors, in particular the solvency of the issuer and the remaining maturity of the bond.

Many securities are listed and traded at regulated Stock Exchanges; paralle to this exists the over-the-counter market, which is less (or not) regulated. Most bond trading in the DAEs occurs via this 'OTC' market. The change of ownership and the payment for the transaction (the clearing and settlement) usually occur through separate mechanisms, up to several days after the transaction.

trading, clearing and rating systems the question of how much debt should be carried on the balance sheet ought to be a matter of each company's decision on capital structure rather than an object of regulatory interest. These statutory restrictions are in line with the one that exists in Japan: article 297 of the Commercial Code of Japan stipulates that the total value of bonds a company can issue is limited to the smaller of its capital plus its reserve fund or its net asset value. With secured bonds, convertible debt and foreign bonds, this ceiling is doubled.

\section{Excluding Retail Investors}

The limited base of individual investors in the six DAEs is a further reason for the under-development of the fixedincome securities markets. Retail investors are in many instances discouraged from investing in fixed-income securities by large minimum denominations, which are usually well beyond their reach. The issuers of debt securities are largely restricted to government institutions, financial institutions, and public and large private corporations, and the buyers are almost exclusively institutional investors. For example, the Hong Kong Association of Banks prohibits its members from issuing certificates of deposit (short-term debt securities) with denomination below $\mathrm{HK} \$ 500,000$ (US\$64,000). In this case the measure could be seen as protectionist, since it robs retail investors of an alternative for bank deposits. Some

\begin{tabular}{|c|c|c|c|c|c|c|}
\hline \multicolumn{7}{|c|}{$\begin{array}{l}\text { Table } 3 \\
\text { SECONDARY MARKETS IN DAES } \\
\text { December } 1991\end{array}$} \\
\hline & Hong Kong & Korea & Malaysia & Singapore & Taiwan & Thailand \\
\hline $\begin{array}{l}\text { Market Size (US\$ billion) } \\
\text { Government bonds } \\
\text { Corporate bonds } \\
\text { Total }\end{array}$ & $\begin{array}{r}122.80 \\
0.08 \\
0.99 \\
1.07\end{array}$ & $\begin{array}{r}176.93 \\
42.39 \\
38.43 \\
80.82 \\
\end{array}$ & $\begin{array}{r}86.13 \\
24.01 \\
2.89 \\
26.90\end{array}$ & $\begin{array}{r}67.38 \\
5.94 \\
1.46 \\
7.40\end{array}$ & $\begin{array}{r}140.94 \\
13.50 \\
3.79 \\
17.29 \\
\end{array}$ & $\begin{array}{r}40.61 \\
5.58 \\
0.13 \\
5.71\end{array}$ \\
\hline $\begin{array}{l}\text { Trading Volume (US\$ billion) } \\
\text { Government bonds } \\
\text { Corporate bonds } \\
\text { Total }\end{array}$ & $\begin{array}{l}0.31 \\
0.03^{a} \\
0.34\end{array}$ & $\begin{array}{l}50.13 \\
25.03 \\
75.16 \\
\end{array}$ & $\begin{array}{l}2.83 \\
0.35 \\
3.79 \\
\end{array}$ & $\begin{array}{r}10.73 \\
1.59 \\
12.32 \\
\end{array}$ & $\begin{array}{r}145.36 \\
0.08 \\
145.44 \\
\end{array}$ & $\begin{array}{l}0.0030 \\
0.0052 \\
0.0082 \\
\end{array}$ \\
\hline $\begin{array}{l}\text { Turnover Ratio (\%) } \\
\text { Government bonds } \\
\text { Corporate bonds } \\
\text { Total }\end{array}$ & $\begin{array}{c}406.70^{\circ} \\
3.06 \\
23.39\end{array}$ & $\begin{array}{r}118.26 \\
65.13 \\
93.00\end{array}$ & $\begin{array}{l}11.78 \\
12.20 \\
14.09\end{array}$ & $\begin{array}{l}180.64 \\
108.90 \\
166.49 \\
\end{array}$ & $\begin{array}{r}1,077.00 \\
2.11 \\
841.18\end{array}$ & $\begin{array}{l}0.05 \\
3.89 \\
0.14\end{array}$ \\
\hline \multicolumn{7}{|c|}{$\begin{array}{l}\text { Notes: } \\
\text { a. Including over-the-counter trading. } \\
\text { b. Trading in government bonds began only in November } 1991 . \\
\text { Source: OECD }\end{array}$} \\
\hline
\end{tabular}


governments regard minimum denominations as prudential: barring small, unsophisticated investors from the market reduces the call for investor protection.

Indeed, the holders of debt securities are largely institutional investors, such as investment or pension funds, or large financial institutions. Over $90 \%$ of the bills issued by the Office of the Exchange Fund in Hong Kong are reportedly held a competitive auction system for government securities, which is common in developed financial markets. In spite of the large volume reported in the primary market, Korea relies on an allocation scheme and an underwriting syndicate rather than on the auction of new issues of government and municipal bonds. The auction technique has never been used for government bonds in Thailand.



by financial institutions. In Thailand 93\% of government bonds are held by financial institutions. In Korea no more than $3 \%$ of individual investors' investments are in debt securities, and approximately $65 \%$ are with the banking institutions in the form of deposits and cash. By contrast, the amount of individual holdings in long-term fixed income securities is about $25 \%$ in the United States and $30 \%$ in Germany.

\section{The Securities Infrastructure}

A substantial expansion of DAE bond markets requires several improvements in the infrastructure of these markets. Korea and Thailand have yet to adopt
Another shortcoming is the lack of rating agencies, institutions that provide prospective buyers of bonds with an assessment of the creditworthiness of the issuer. There are no local bond-rating agencies in Hong Kong, Singapore, Taiwan and Thailand. Korea, though, has three rating agencies under the supervision of the Securities and Exchange Commission. Issuing corporations are obliged to have their (unsecured) bonds and overseas debt securities rated. Short-term debt securities, not guaranteed by collateral and issued by firms with net sales of no less than 10 billion won (about US\$13 million), are also required to have a rating. The Rating Agency of Malaysia was incorporated as an independent, privately owned, credit-rating agency at the initiative of the Bank Negara Malaysia. By the end of March 1992 it had completed the rating of three debt issues.

There is also scope for further development of the clearing and settlement systems in DAE bond markets. This is most easily done through a central system. The securities do not physically change hands but are kept in a central depository, while a change of ownership is only registered in the books. There is 'delivery $v$. payment', among other safeguards against the failure of one party to meet its obligations to the other. In some countries, like Singapore, Malaysia and Hong Kong, government securities do not exist in paper form, but only electronically. In Korea, Taiwan and Thailand the 'over-the-counter' markets (where more than $90 \%$ of bond trading is done) do not have systems of centralised clearing, settlement and central depositories.

\section{출 졸}

These obstacles constitute the main policy issues to be addressed by DAEs aiming at a larger role for fixed-income securities in mobilising domestic savings. Although these markets are only at an early stage of development, all six DAEs share the goal of developing domestic debt markets and place the highest priority on formulating policy measures to that end.



\section{OECD Bibliography}

- Emerging Bond Markets in the Dynamic Asian Economies, forthcoming 1993

- Günther Bröker, Government Debt

Management and Govemment

Securities in the 1990s,

forthcoming 1993

- S. Ghon Rhee, Securities Markets and Systemic Risks in the Dynamic

Asian Economies, 1992

- Risk Taking in Financial Services 1992

- Systemic Risks in Securities Markets, 1991. 


\section{Radical Reform \\ for Swedish Education}

George Papadopoulos

Traditionally, education in Sweden was intended to support a dynamic and egalitarian society that was also economically efficient. Although that objective remains the same, the approach to it is coming under scrutiny, prompting some fundamental rethinking of the established pattern of educational goals and a re-examination of educational priorities. ${ }^{1}$

$\mathbf{T}$ he Swedish education system has always been sensitive to the broader political, social and economic context within which it operates, since it was seen as an important instrument in shaping the development of Swedish society - an investment in 'social engineering', as some commentators claimed. Three changes in the wider policy framework will affect education in particular.

First, Sweden is moving away from its traditional neutrality, seeking its way toward integration into the European Community. Second, and as in so many other industrialised countries, the social and economic climate has changed. Unemployment has risen to volumes which, although relatively low by international standards, are unprecedented in Sweden. Many people are now expressing their concern that the country may not have the economic capacity to sustain its competitiveness in the world market and generate the resources necessary to sustain the large volume of public spending on which the 'Swedish model' of social 'consensus', full employment and the welfare society was traditionally based. Third, the advent in 1988 of the Conservative-led coalition government has brought a set of de-

George Papadopoulos was formeriy Deputy Director for educational questions of the OECD Directorate for Education, Employment, Labour, and Social Affairs; he is now a consultant to the OECD. clared policy objectives and a new political discourse. Its liberal ideology reverses some of the fundamental precepts which guided the development of Swedish education, and of Swedish society more broadly, during the long dominance of the Social Democrats.

\section{Decentralisation and Devolution}

Traditionally, education in Sweden, as other sectors of public policy, was part of a centrally planned system. Objectives were set nationally and decisions pre-

1. Reviews of National Policies for Education:
Sweden, OECD Publications, Paris, forthcoming 1993.

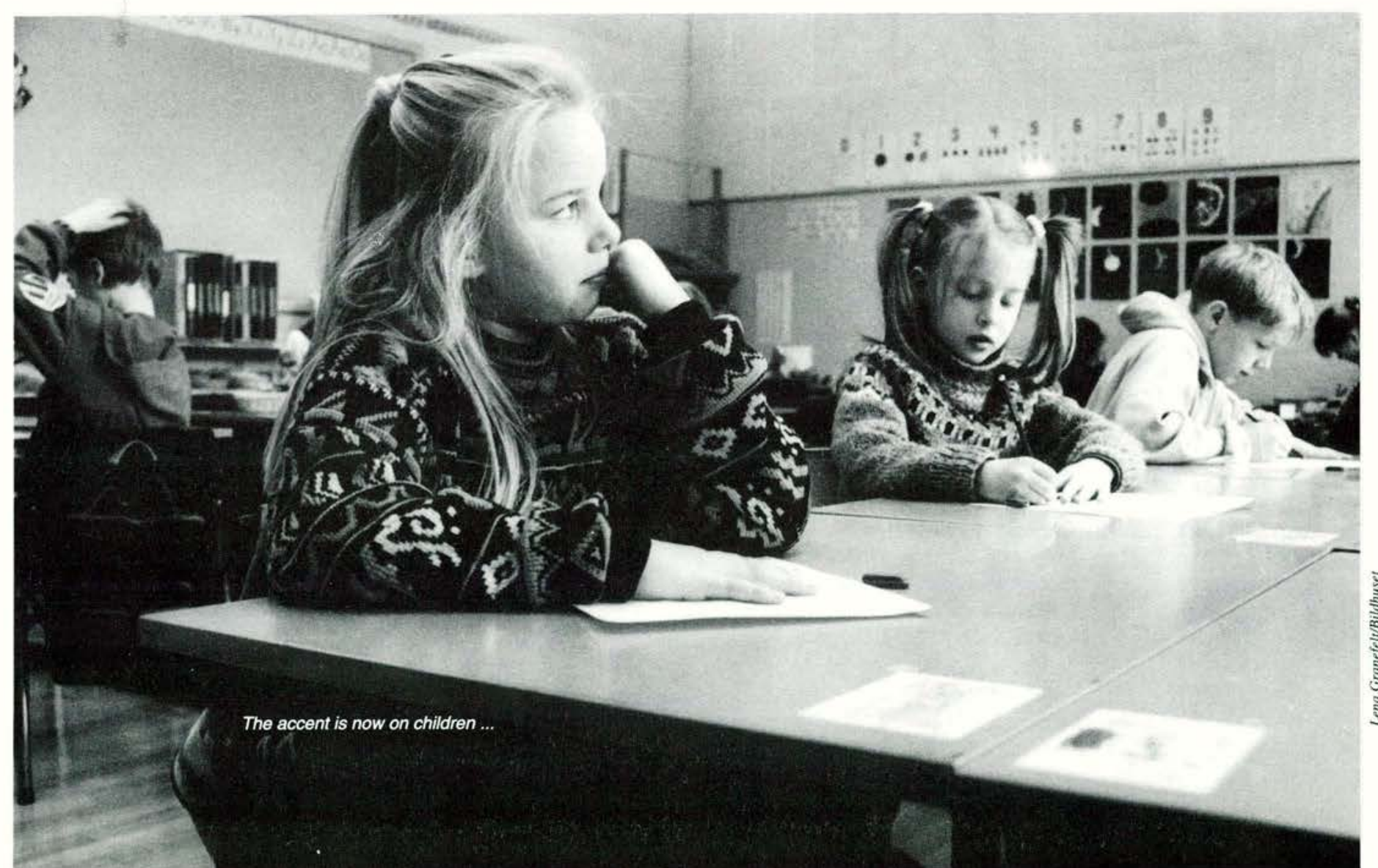


pared through a time-consuming political process of national commissions, often after protracted sessions that attempted to establish consensus. The basis of the process was an extensive amount of research; and the commissions in which decisions were prepared offered a reasonable amount of representation to the interest-groups and the people who would have to implement the decisions locally. Co-ordination, supervision and developmental functions were in the hands of two administrative, professionally led state agencies - the National Board of Education and the National Board of Universities and Colleges over which the Ministry of Education has no direct control. These arrangements left considerable scope for managerial decisions in the municipalities and educational institutions themselves, although they always took place within a framework of centrally prescribed objectives and regulations. The accent was on uniformity as the guarantor of equal standards across the country.

This 'top-down' model worked well during a long period of social and political consensus, uninterrupted growth in productivity and relatively few restraints on public spending. But by the mid-1970s, as faith in centralism began to waver and political consensus started to disappear, there were clear signs that a redefinition of the relationship between the centre and periphery, between politicians and professionals, was required. The communities thus gradually acquired more authority and the educational institutions more freedom within centrally set targets - to make their own choices about curriculum, definition of courses, number of places, and so on.

This movement gained momentum and growing political recognition throughout the ' 80 s, culminating in the radical reforms of 1990-91, the last years of the Social Democrat government. The National Board of Education was abolished, block grants (un-earmarked subsidies from central government) were transferred to the municipalities, and secondary education underwent a major restructuring. And the National Board of Universities and Colleges has been replaced by two separate units that perform essential services (such as co-ordinating the candidatures of firstyear students) and evaluation tasks respectively. The new government pursued these reforms, thus formally cementing the principle of decentralisation accompanied by even stronger deregulation. Concomitantly, there has been a new emphasis on differentation between schools, between higher education institutions and between the courses offered by these institutions.

This 'open goals' approach of local responsibility is quite new in Swedish policy-making. And it brings into prominence a new role for the state in setting a broad national framework within which this freedom can be exercised, and in ensuring equality of provision across the country and the maintenance of quality and standards. Monitoring and evaluation thus replace steering and supervision as the main functions of the ministry and state agencies.

\section{Objectives and Priorities}

The full impact of decentralisation can best be measured when seen against the guiding principles the new government has set for its educational policy: to develop further the freedom of institutions and choice for individuals; and to strengthen the quality of Swedish education and raise its international standing. The two are seen as mutually reinforcing, with the explicit objective of developing a more dynamic and pluralistic society in which individual choice and competition among institutions together help promote the quality of education.

The perception of 'quality' itself has also changed. There is a new accent on child and youth education after years of policy which gave priority to adults. This was reflected in the cut-backs in the 1992-93 budget for certain kinds of adult education and the debate on the abolition of the ' $25+4$ ' rule that enabled adults who had four years' work experience but who were not qualified

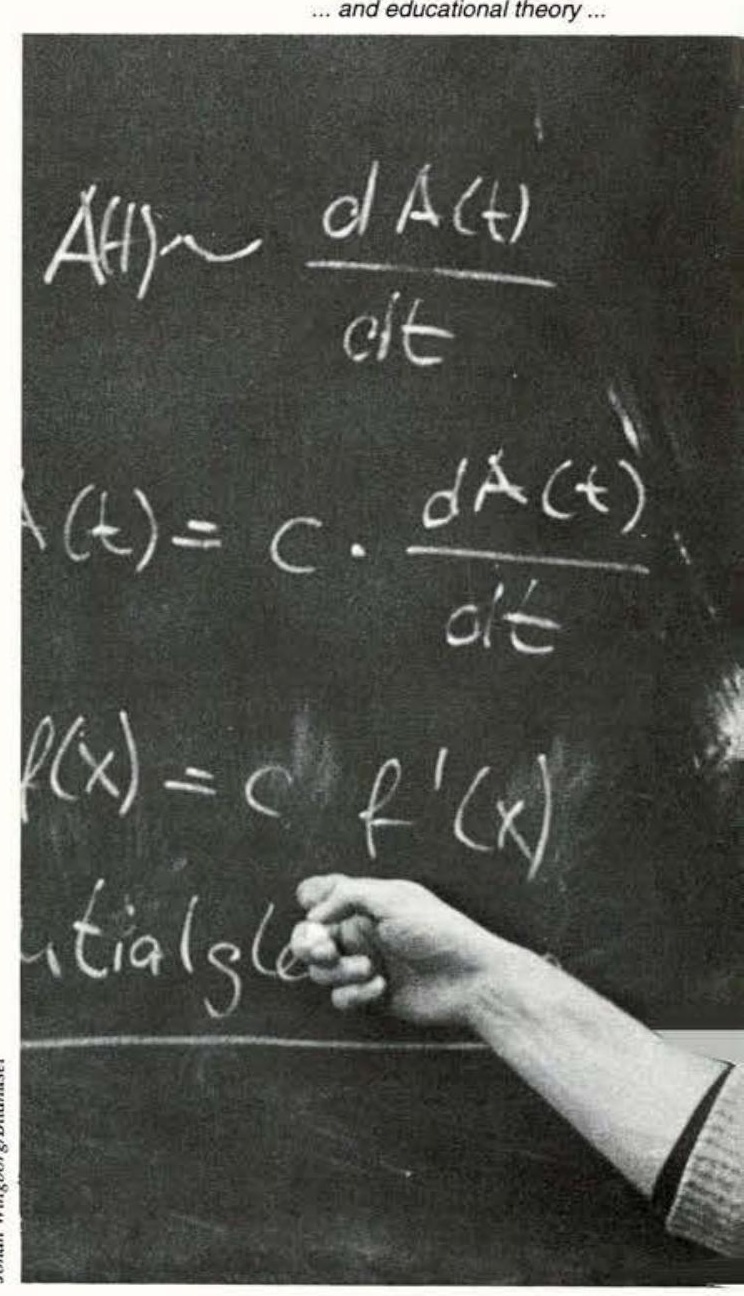

for university to benefit from higher education.

There has also been a clear move away from a pupil-centred approach to schooling and the role of schools in social and personal development towards the acquisition of subject knowledge and, in general, a reinforcement of the academic component of education. Marks will now be given in individual subjects whatever inter-disciplinary grouping may be used in the way individual schools and classes organise their instruction.

The same tendency is observed in the restructuring of degree courses and in the definition of criteria for access to higher education, with a new accent on academic qualifications. It is also reflected in the new scheme for teacher 




education for lower-secondary classes still in compulsory education, with a three-year academic course to be followed by one year of professional training - a sequential system that will co-exist with the integrated one which has prevailed so far, in which academic and professional preparation were integrated throughout the duration of teacher training. The government argues that the new scheme will increase individual choice (since after a specialised bachelor degree a student could opt for teacher training) and thus enhance recruitment into the teaching profession.

Finally, the procedures for monitoring pupil performance and the whole school system will be revised with the intention of 'making schools more demanding' in the acquisition of knowledge. Individual marks will be introduced at an earlier stage. And the previous system, where marks were group-referenced (through the average achieved by a group of pupils), will be replaced by a goalsreferenced system in which the achievements of individual pupils will be judged against the standards set for each subject in the curriculum. A new national curriculum is being devised, setting out the core subjects which all schools should teach, and also defining the goals which pupils have to reach within five and nine years of study.

\section{A New Style of Policy-making}

The often protracted process of reform through special commissions generated an impressive volume of research and development activity, including pilot experimentation, to substantiate decisions on policy. It also kept these decisions and their application in the public eye.

The procedure is now different. Policy decisions are prepared in a purely political context with relatively little prior 'homework' and with considerations of implementation left rather vague. Instead of pilot experimentation, effort is now concentrated on pushing through rapidly a number of landmark changes, even if on a small scale: there are, for example, negotiations in hand with a small number of higher-education institutions with the aim of converting them into independent trusts or foundations. And attention is being paid to the setting-up of a number of private schools.

There is no doubt that this approach to policy-making has its merits. It reduces the time between government decisions and their translation into action. It also gives precedence to the political context of these decisions over that of interest-groups and 'experts'. On the other hand, this relative openness may convey the impression that it is not backed by an adequate amount of professional and informed analysis and that it is not related to an identifiable long-term strategy. And although that may well be deliberate, allowing a strategy to evolve rather than be imposed, it nonetheless puts a premium on special efforts by the ministry to improve communication with its local partners in order to reduce the degree of uncertainty about the aims behind policy pronouncements and measures.

Another priority to emerge from the 1992-93 budget was the precedence of school education, higher education and research over 'folk high schools', study associations and municipal adult education. To a foreign observer, this comes as a surprise, as does the scant attention given to the co-ordination of educational policy with industrial and employment policies - especially when almost everyone in Sweden attaches considerable importance to the development of human resources as an essential contribution to the dynamism and competiveness of the Swedish economy.

It is true that the extension of vocational lines in upper secondary schools from two to three years indicates that the government recognises the importance of reinforcing the technical and general skills of younger entrants into the labour force. But the additional funding necessary for this reform has yet to be provided. Priority, instead, has been given to increasing the intake into higher education, particularly in engineering and the natural sciences, and to improving research with the objective of doubling the number of doctorates by the year 2000 .

The government has explicitly linked quality in education with the new international position of Sweden, particularly its increased integration with the European Community. Specific measures are being taken to strengthen foreignlanguage training throughout the educational system, to internationalise the content of education towards deeper understanding of foreign cultures, in schools as well as in universities, to increase exchange activities and the opportunities of Swedish students to study abroad, and to promote European co-operation in education and research. It is to be hoped that this programme does not neglect the argument that internationalisation is broader than 
'Europeanisation', particularly for a country like Sweden which has a long tradition of involvement in the developing world.

\section{Steering and Evaluation}

In a highly decentralised, deregulated system, one which encourages competition and choice as the springboards of high standards and quality, ensuring the necessary national steering becomes a principal concern of central policy-making, with evaluation as its main instrument.

School evaluation is the main task of the National Agency for Education and, for universities, of the Evaluation Unit for Universities. Their authority emanates from government/parliament rather than the Ministry of Education. Evaluation of schools will be based on statistics of performance as well as qualitative judgments and will be combined with advice and other support facilities designed to remedy observed deficiencies. It is thus designed to serve as an instrument both of control and of pedagogical and developmental functions. No doubt, the 'watch-dog' function of the two agencies involved will serve as a stimulus to individual municipalities and to schools to keep their standards up and conform to the goals set in the national curriculum. So will the publication of ratings.

The same principles will apply to universities, and to individual faculties within them, although here the effect of publicity will be in itself more important. This explains the enthusiasm with which universities themselves are beginning to indulge in self-evaluation. No activities of parallel intensity can be observed in schools, where accountability is not yet part of the culture.

The determining factor in the value of evaluation will be the attitude of the political leadership: whether they see it primarily as an instrument for rewarding good performance and correcting bad results, or as a major pedagogical tool to help all schools in their search for quality education. This challenge is not unique to Sweden.
That competition and choice lead to quality is the axiom on which markets operate. Carried to its logical conclusion, it implies the development of an educational market which, in the Swedish context, will nonetheless remain largely within the public sector. That is in spite of the declared aim of the government to encourage the growth of private schools and of independent universities, supported by public finance on the same basis as public schools under a money-follows-the-pupil formula, so as to increase opportunities for choice and serve as a catalyst for change.

But in practice, choice and competition will operate within municipal school districts and between individual schools and universities in the public domain. The general expectation is that the existing order will be only marginally disturbed, first because of the generally high quality of schooling around the country, and second because of the obligation of municipalities to cater in the first place to pupils living within their areas.

\section{술 들}

With the system only now beginning to be applied, it is difficult to tell whether expectations will be fulfilled. The government's intention to make better what is already recognised as good - to establish peaks of excellence in order to pull the existing plateau of quality upwards - runs the risk of penalising the rest of the system. Poor municipalities, for example, will not be able to compete with the more affluent ones in the recruitment of high-quality - and therefore more expensive - teachers, or in the provision of facilities and range of curricula that would make their schools attractive. Private schools may charge special fees, thus bringing in only pupils whose parents can afford the extra expenditure. The use of household expenditure for the education of children is something quite new in most Swedish families.

The central dilemma is thus two-fold: how to ensure that the quest for quality does not lead to, or reinforce, socially



... and no longer on adults.

based degrees of inequality; and how the encouragement of local variation will not weaken national standards and requirements. Sweden's chosen instruments for tackling this dilemma are, first, the system of block grants to municipalities; second, the definition of a national curriculum and of minimum requirements for university degrees; and third, the installation of a central system to evaluate educational performance in municipalities, schools and institutions of higher education. The results of this bold change of course will be awaited with interest by other countries facing similar problems.

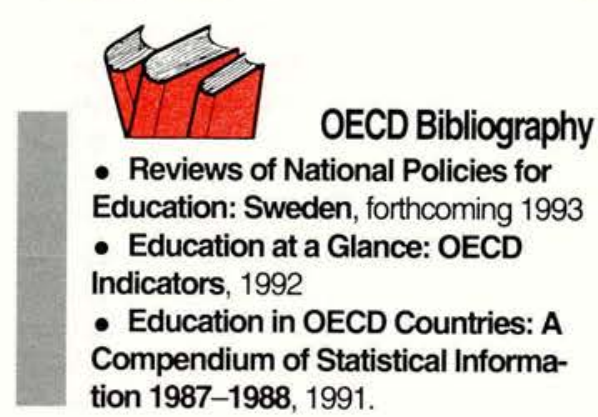






\section{It is widely recognised that more adult participation in education and training can contribute to both the economic and the social well-being of OECD countries. But there are limits to how far adult learning habits can be influenced nationally - through government policy, for example. More local strategies, particularly in cities, could play an important role. ${ }^{1}$}

W hat do a redundant Pittsburgh steelworker, a bored Viennese housewife and an octogenarian in Kakegawa, the "green tea capital' of Japan, have in common? Each lives in a city which, in its own way, values and encourages life-long learning. And each might use a return to education or training as a means of changing his or her life.

'Life-long learning' is the idea that education and training should not come to an abrupt end at the age of, say, 16,18 or 21 . It is widely preached and patchily practised in OECD countries. But it is becoming increasingly popular, for two broad reasons. First, many individual benefits are now associated with adult learning in, for example, job mobility, personal fulfilment and the ability to function effectively in an increasingly complex world. Second, successful economic performance has been shown to require improvements in the training and education of adult workers. ${ }^{2}$ Since only about $2 \%$ of the workforce is 'renewed' by young entrants each year, improvements in youth education alone would not raise the quality for over two decades.

The kind of learning that is being advocated for adults takes a variety of forms. At the most basic level, literacy courses are required to allow many

Donald Hirsch works on issues related to human resources in the Centre for Educational Research and Innovation of the OECD Directorate for Education, Employment, Labour and Social Affairs. adults to cope adequately with written texts in their daily lives and in work. Vocational courses provide not only full-time induction into occupations for teenagers but also regular upgrading, often on a part-time basis, for adults in work. And the variety of non-workrelated courses being offered, in adult education classes or community colleges, may be designed not merely for intellectual stimulation but also for their usefulness in changing life patterns: foreign languages for citizens who are travelling more, understanding of administrative and political structures for con-

\footnotetext{
1. City Strategies for Lifelong Learning, OECD Publications, Paris, forthcoming 1993.

2. Adult Illiteracy and Economic Performance, $O E C D$ Publications, Paris, 1992.
} 


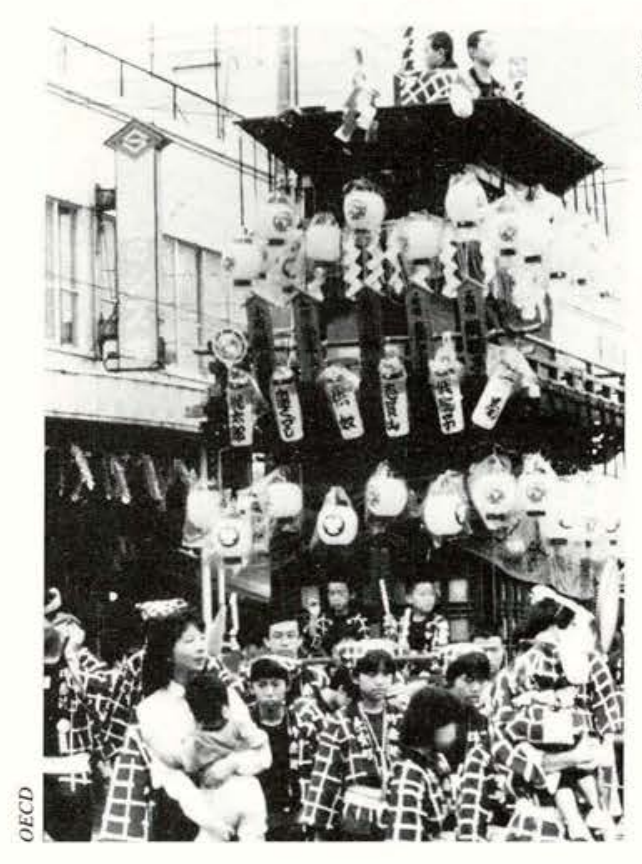

sumers of public services where decision-making is being decentralised, and so on.

But the calls from politicians, economists and educationalists for a life-long approach to learning have yet to break long-established emphasis in educational systems on youth either in the allocation of most education and training resources or in the distribution of participants across age-groups. This is not only a matter of inadequate supply of programmes: lack of demand from adults for courses can be as important a constraint. In countries where support for the concept of life-long learning is strongest, there is often a long-established culture of participation. Every year something like 1.5 million out of 6.8 million adult Swedes, for example, attend informal 'study circles'.

Cultural habits are hard to change through national policy decisions. Locally, though, there may be more scope for initiatives that encourage the population to take further learning seriously. In cities, home to the majority of people in OECD countries (some $60 \%$ live in cities of over 100,000), there is growing pressure for locally managed solutions to urban problems, which revive confidence in the city as a place. Life-long learning can be one common objective that helps create a sense of purpose in a city.

In the abstract, this goal sounds high-minded, even utopian. In reality,
Kakegawa, faced with competition from Tokyo for its population, has actively emphasised the town's history and culture.

some individual cities have already gone a long way down the road to creating a culture of life-long learning. The OECD has studied seven cities in four continents. ${ }^{3}$ Several features stand out. What helps most is a strong desire on the part of a range of local organisations, public and private, and not only the city authorities - to achieve some change in the city through the encouragement of life-long learning. This condition is clearly present in two of the most striking examples: Pittsburgh in the United States, and Kakegawa in Japan.

\section{Rejuvenation through Education?}

Between 1976 and 1983, when its steel industry collapsed, Pittsburgh lost about 100,000 jobs and the heart of its economy. Since then, every effort has been made by the authorities and others to retrain displaced workers. Buteconomic adversity has also resulted in broader attempts to create a new identity for the city, as its inhabitants learn not only new work skills but new ways of living in communities where life nolonger revolves around each local mill. Local government in Pittsburgh is heavily fragmented, so these efforts have involved new coalitions attempting to co-ordinate the efforts of both public and private organisations with an interest in life-long learning. These motley coalitions include, for example, the community college, the county welfare service, the city's larger employers and the steelworkers' union.

In Japan, by contrast, an important impetus behind a conscious attempt to create an ethos conducive to life-long learning has been the specific commitments of municipal governments. In Kakegawa, which in 1979 became the first place in Japan to declare itself a 'city of life-long learning', a strong mayor takes a clear lead. Here, as in Pittsburgh, the movement originates from an economic necessity - but of a different sort. Kakegawa is a small country town that is losing population to Tokyo as its agricultural and forestry industries decline. In an effort to bring people and companies to the city, the authorities have tried to make it a more attractive place to live. This policy has involved encouraging people to learn about the town's history and culture, and to take an active part in its regeneration.

As elsewhere in Japan, one aim is to make adults interested in learning for leisure rather than focusing their whole lives on work. Another is to provide interest for the growing number of old people, in a country where life expectancy is higher than anywhere else in the OECD. Japan still has a relatively low proportion of old people, but that position is rapidly being reversed: between 1980 and 2020 the number of over-65s will increase from around $6 \%$ to over $20 \%$ of the population, overtaking most other large OECD countries.

Life-long learning thus can be spurred by a conscious desire of a city administration to change its character. But what are the other essential ingredients of a 'learning city'? In each one, the situation is different, but a number of common elements can be discussed.

\section{Four Paths to Life-long Learning}

First, there is the willingness of many different 'actors' in the city to work together. Municipal authorities rarely have a monopoly of responsibility for education and training. Where private organisations work with public ones, there is more chance that a common message in favour of life-long learning comes across to the potential 'consumers' of education and training whether workers who see the value of asking their employers to train them, retired people persuaded to do something more creative than sit in front of the television, or relatively uneducated parents made aware of opportunities for learning to read and write alongside their children.

'Compacts' between employers and education authorities in North American

\footnotetext{
3. The seven cities are Edmonton, Pittsburgh, Bologna, Gothenburg, Vienna, Kakegawa and Adelaide.

4. Christopher Brooks, 'Rethinking the City', The OECD Observer, No. 178, October/November 1992; see also pp. 14-17.
} 
and European cities show how such coalitions can have a city focus. The Boston Compact and the East London Compact, for example, were based on the urban incongruity of inner-city unemployment existing a stone's throw from thriving central financial districts. City-centre employers undertook to give jobs to youngsters from certain high schools in deprived areas, provided they fulfilled certain minimum learning requirements.

Second, there is the existence of defined learning cultures on which a city might build. A historic city like Vienna or Bologna has some advantage in its citizens' identification with its history and their interest in its artistic achievements. But as important can be the traditions, often more recently established, of popular participation in learning. In Vienna, an extensive network of Volkshochschulen, 'people's colleges', which has grown up over the past century, has helped establish an ethos of neigh-

The Happy Days in Pittsburgh went when the steel industry collapsed in the late 1970s and early '80s.



bourhood access to courses: there are 16 colleges spread over 150 sites. In Bologna, worker training has been shaped by a distinctive pattern of work organisation: skilled workers in small, specialised companies get training support from trade associations, which receive financial support from the authorities. In Edmonton (Alberta), a young city that celebrated its centenary only last year, a strong tradition of participation in learning through voluntary clubs and associations has already been created.

Third, there is a high degree of integration between learning and other aspects of city life. There has been a tendency in many countries for adult education to take place in the isolated setting of the college classroom. Since many adults have no desire to return there, it can deter many potential learners. In Gothenburg, a new 'knowledge centre' being developed on a former shipyard is attempting to combine production (in 'heavy' industries, such as engineering, as well as in services, such as restaurants and shops), practical learning and theoretical learning on a single site. In Edmonton, art students work with top artists to prepare one of the city's many street festivals. When the biggest shopping mall in the United States, the Mall of America, opened just south of Minneapolis in 1992, it included a $3,000 \mathrm{~m}^{2}$ 'learning laboratory', a collaboration between five school districts and the businesses in the mall to provide child-care, secondary education and work experience, adult education and training in a flexible environment. Could shopping become the latest activity in the life of the city to be combined with learning?

Fourth, there are clear channels of information from suppliers to consumers. Since adult education and training are not generally provided by a single, centralised service, information about what is on offer can be disparate and inaccessible. In cities, information can be collated about what is on offer (as educators in Edmonton have done in a special tabloid newspaper). Local newspapers, radio and television sta- tions are often willing to co-operate in spreading the word. There can be a strong element of self-interest involved, since an ill-educated citizenry tends not to read newspapers. Indeed, the Association of Austrian Newspaper Proprietors recently ran a high-profile adult-literacy campaign entitled 'Lesen ist mehr' - 'reading is more'.

$$
\text { aㅣ }
$$

At a recent conference on the problems of cities held by the OECD ${ }^{4}$ a central theme that emerged was the dissatisfaction of urban dwellers with the quality of their lives, and their tendency to blame the politicians, planners, developers and others who had created what was seen as the urban morass. The solutions suggested so far have tended to concentrate on putting more power into the hands of urban dwellers themselves.

But many citizens do not see an obvious way of using such power. Life-long learning organised on a city or community basis can both enhance community consciousness and provide individuals with the skills they require to influence change - by making their views known clearly to local governments and businesses, and by getting involved directly in voluntary projects to improve their local environment. Individual and community learning can thus be linked: citizens who are ready to learn how to change their own future will be better placed to play a part in the destiny of their immediate environment.

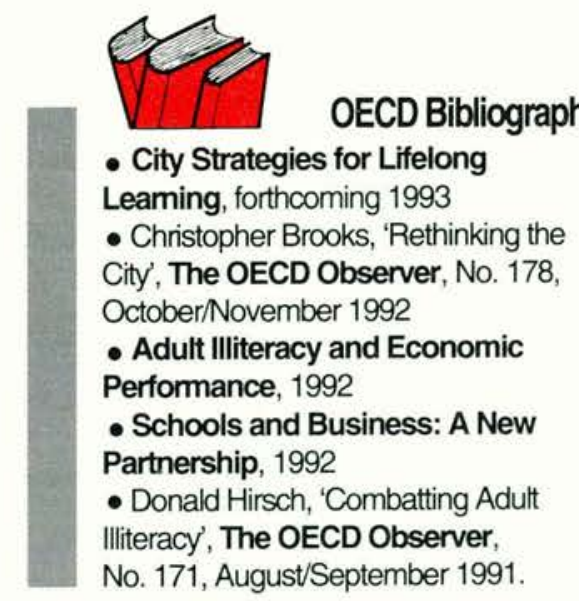




\title{
Marketing \\ Traffic Safety
}

Antonios Barbas and Burkhard Horn

\begin{abstract}
Every year 120,000 people are killed on the roads of OECD countries, 400,000 worldwide. To reduce this enormous death toll and economic losses associated with traffic accidents, current approaches to road safety have to be revised and enhanced. The use of 'social marketing' offers the potential to improve the effectiveness of a wide range of accident counter-measures and road-safety programmes. ${ }^{1}$
\end{abstract}

mportant advances in road safety have been achieved through drunkdriving legislation, more stringent application of speed limits and the compulsory wearing of seat belts. In recent years, too, progress has been made through integrated safety programmes and institutional adjustments, such as targeted police enforcement, policies that reward safe driving, the support of automobile insurers for accident-prevention activities, and incentives for modifying the behaviour and attitudes of road-users.

For the last 25 years, indeed, the OECD Road Transport Research Programme has been systematically assessing and promoting a variety of innovative safety measures in road design and traffic operation, vehicle use and road-user education. It is now increasingly recognised that traffic-safety policies must be made on a system-wide basis, embracing a broader span of objectives, and involving a wider range of expertise from different traffic systems - and that networking between action groups and communication with road users is therefore essential. Such a shift into consumer orientation is the essence of marketing traffic safety.

One of the central ideas of marketing a product is to make it appear more attractive. The promotion of road safety



HIT AT 20 MPH, 19 OUT OF 20 CHILDREN SURVIVE.

KILL YOUR SPEED. NOT A CHILD.)

can be especially difficult, since the motivation for safe behaviour is often simply absent among road users, and commercial interests and social objectives towards safety may be in conflict.

Burkhard Horn is Head of, and Antonios Barbas a transport engineer in, the Road Transport Research Programme of the OECD Directorate for Science, Technology and Industry.
'Social marketing', furthermore, differs from the conventional approaches applied in road safety, which consist mainly of engineering, education and enforcement methods. It is a complementary approach that is strongly consumeroriented and can stimulate and support road-safety publicity campaigns, education, training, even the introduction of legislation.

Social marketing involves the design, implementation and monitoring of programmes to increase the acceptability of an idea, cause or practice in a target group or groups. It uses market segmentation, consumer research, concept development, communication, incentives for users, consumer orientation and/or involvement to maximise the response of target groups.

The application of social marketing in road safety contains distinct elements, many of which are new in productpromotion:

- it focuses much more on the target road-user, on his/her perceptions and motivation, than other approaches

- it requires the road-safety practitioner or policy-maker to adapt set objectives to the perceived requirements, costs and benefits of the target group

- it encourages promotion of remedial

1. Marketing of Traffic Safety, OECD Publications, Paris, forthcoming 1993. 
Figure

\section{MEDIA USED}

IN ROAD-SAFETY CAMPAIGNS

IN 14 OECD COUNTRIES, 1989-90

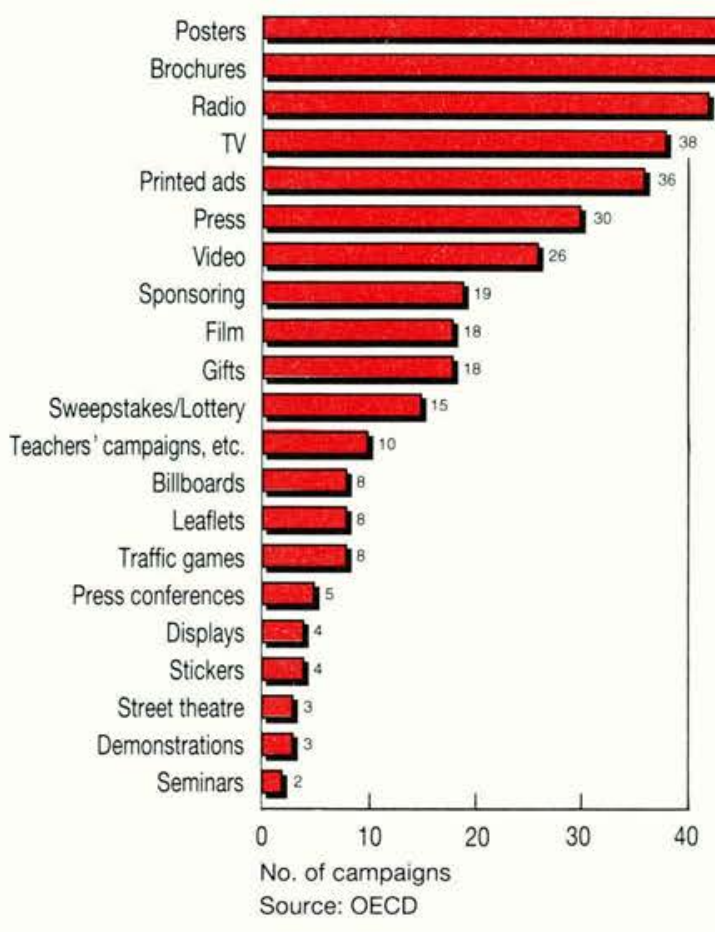

measures and communication with the public on the anticipated benefits and socio-economic costs to be incurred.

A marketing plan begins with an analysis of the situation one wishes to improve. Once the market has been segmented and the target groups iden-

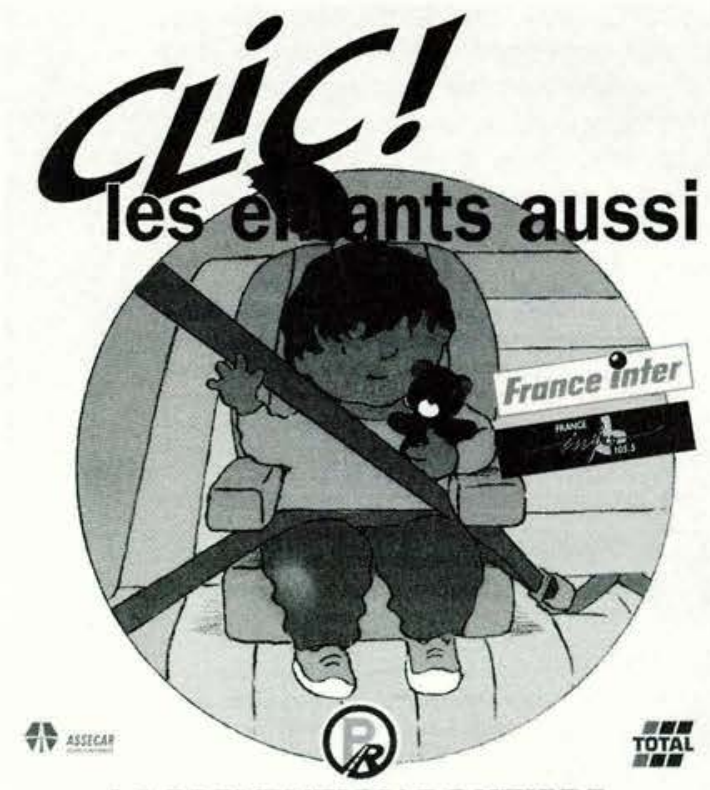

LA PREVENTION ROUTIERE.



tified, objectives are set and the marketing strategies to achieve them are formulated. These strategies often require a sensitive balance of marketing elements - product, price, promotion and place - before an effective socialmarketing initiative can be undertaken. And after its implementation, monitoring and evaluation can feed in information on results that will guide future road-safety initiatives. At all points of this process, indeed, market and consumer research is facilitating the exchange of information and thus allowing substantial improvements in effectiveness.

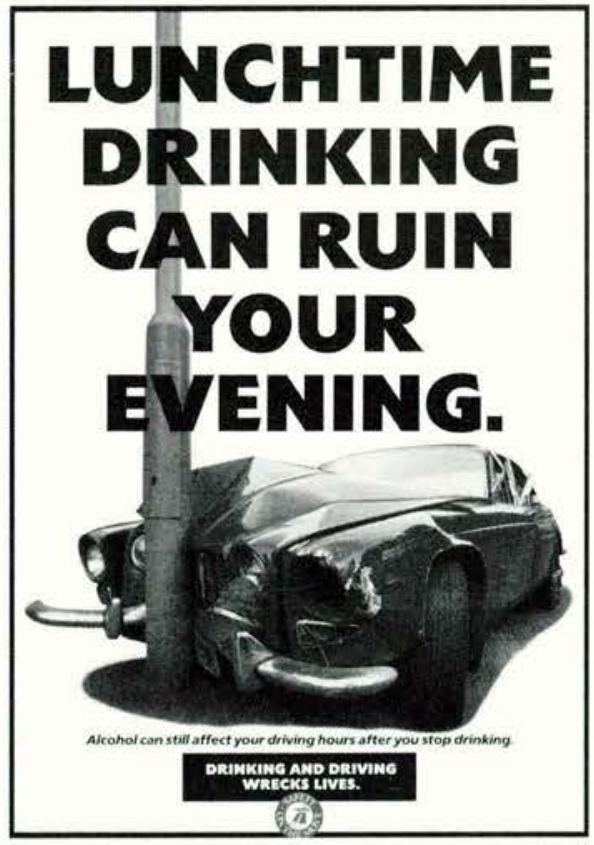

This approach was systematically used in Australia in the late 1980s to promote the use of helmets for cyclists, an activity that still has scope for substantial improvement in most countries, especially since the worldwide fleet of bicycles -800 million - far exceeds the stock of cars as a means of personal transport. In 1992, for example, 92 million bicycles were produced throughout the world, and 35 million automobiles. In all respects, the Australian marketing programme was exemplary in its approach

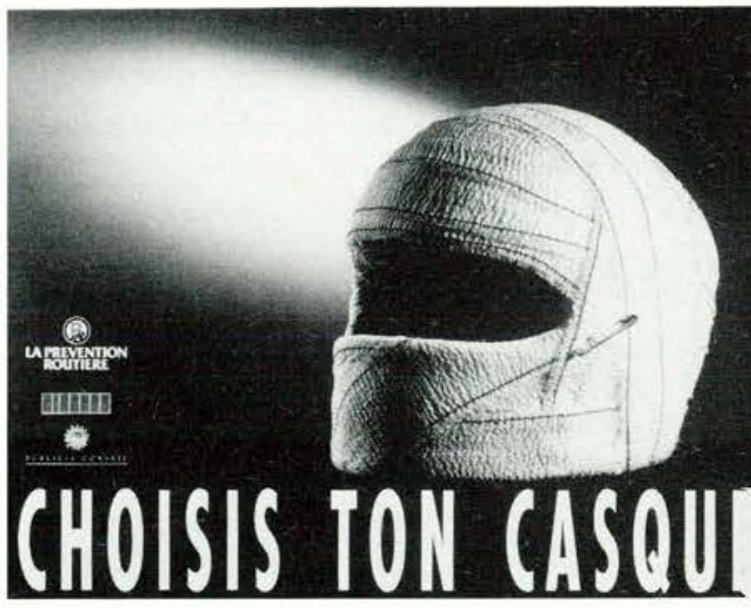

by adapting helmet design to rider preferences and reducing the purchase price of helmets in an effort to overcome dispositions of cyclists against wearing them. The programme resulted in facilitating compliance with legislation to make wearing helmets compulsory which was subsequently introduced, and in reducing head injuries by $20 \%$ within two years.

Among a variety of other successful campaigns, there have been programmes directed at the wearing of seat-belts (again in Australia), child safety (Germany), drunk-driving (Austria and the Netherlands), young drivers (Spain), child pedestrians and the avoidance of speeding (the United States) and child cyclists (the United Kingdom).

\section{Improving Safety Campaigns}

With the aim of developing a marketing concept for traffic safety, the OECD has investigated and assessed the experience and effectiveness of 80 traffic-safety campaigns, a prime area for the use of marketing principles, undertaken in 14 member countries in 1989 and $1990 .^{2}$ The analysis provided detailed information about the work carried out by the institutions responsible for road-safety publicity as well as a first general insight

2. The safety campaigns were conducted in Australia, Austria, Canada, France, Germany, Greece, Italy, the Netherlands, Portugal, Spain, Sweden, Switzerland, the United Kingdom and the United States. 




作

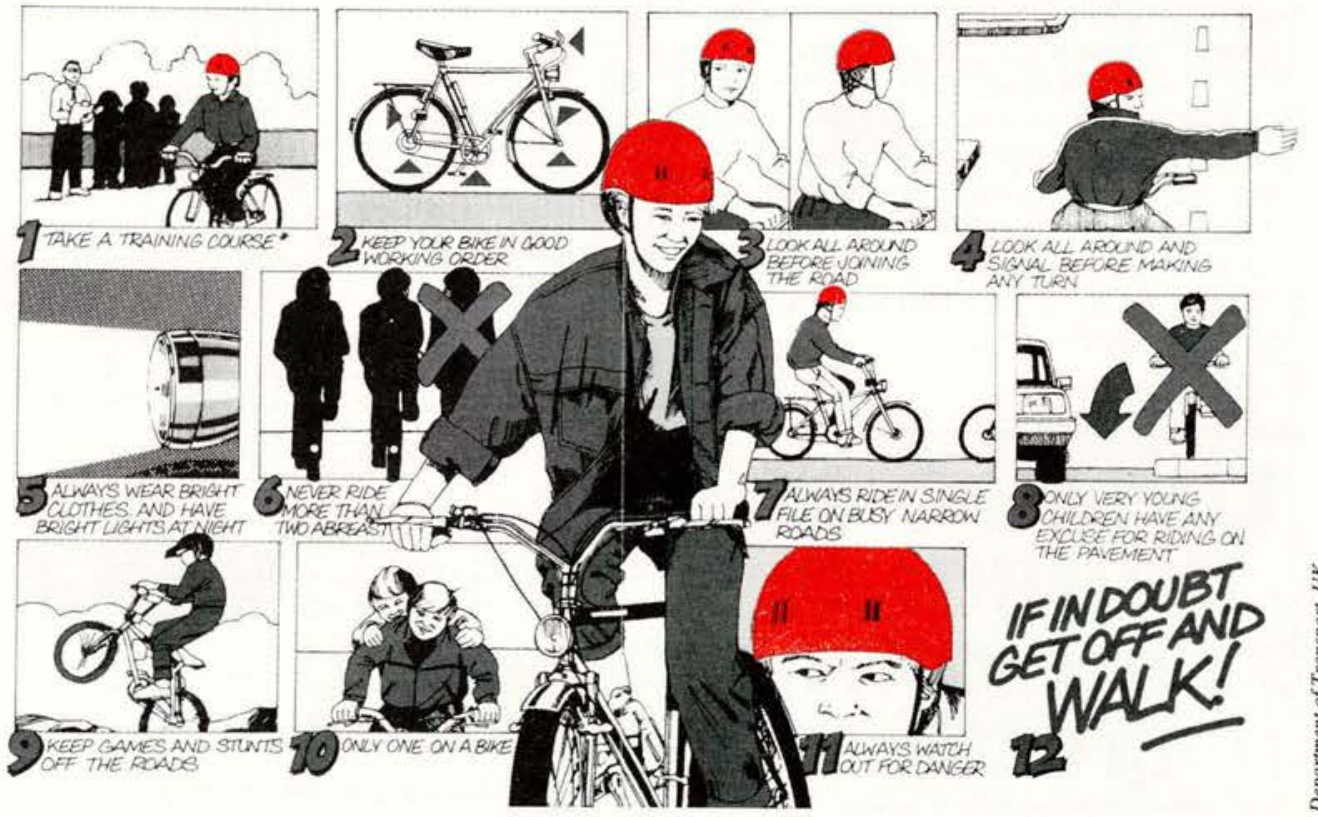

into the applicability of the concept of marketing and its implications for road safety.

The selection of the means of communication used in these campaigns was directly dependent on the target group chosen. Since the habits and lifestyles of such a group can change, the choice of medium, time and location of the communication had to be made anew for each publicity measure and not simply determined on the basis of past experience. The Figure, which shows multiple replies from 80 different campaigns, indicates the wide array of media and tools employed. A surprising finding of the OECD review was that, in spite of the substantial layout necessary for safety campaigns, only two-thirds of the organisations in charge conducted thorough evaluations of their effectiveness. And while the organisations surveyed indicated that they used various marketing elements - research, consumer orientation, media analysis, and so on - very few of them were able to explain the central concepts of a marketing strategy for implementing road-safety publicity measures.

There are two ways of using marketing in road-safety work: applied before the most suitable instrument is chosen, when it therefore has many of the characteristics of a feasibility study

- as a specific method for improving communication between road-safety engineers and policy-makers with road users.

It is essential to promote the requirements of the road-user and take his/ her demands into account, based on a process of communication and exchange between the safety expert and the targeted user. To promote the concept of marketing successfully, one must proceed by analysing both social and user requirements before assessing alternative road-safety strategies and deciding on the most effective instruments to be used.
- as a strategic principle that can be
Social marketing has so far been used to a very limited extent in road-safety work, although the techniques involved seem to provide a valuable extension of the traditional methods of behavioural influence and regulation. The inhibition against using marketing strategies in what is an ideally suited activity has therefore to be overcome.

Moreover, social marketing enhances the cost-effectiveness and productivity of safety measures already undertaken with success. It should not be put off for budgetary reasons, since it will not increase the cost of accident prevention activities: the limited experience to date shows that the additional cost is slight and the improvement in results is particularly cost-effective. Indeed, marketing should be employed as a strategic principle not solely when comprehensive programmes are planned, but also - and perhaps especially - when only modest financial resources are available.

Social marketing is an approach not restricted to a certain area of safety work. Rather, it offers a complementary means of dealing with problems that concern specific target groups. In principle, it is applicable to all areas that are concerned with safety - communication, education, ergonomics, law, engineering sciences related to automobile and road construction, administration - and ought therefore to be more widely accepted and employed.



\section{OECD Bibliography}

- Marketing of Traffic Safety, forthcoming 1993

- Intelligent Vehicle Highway Systems: Review of Field Trials, 1992

- Enforcement and Rewarding:

Strategies and Effects, 1991

- Automobile Insurance and Road

Accident Prevention, 1990

- Behavioural Adaptations to Changes in the Road Transport System, 1990

- Integrated Traffic Safety Management in Urban Areas, 1990. 


\section{The Environment in Eastern Europe: From Red to Green?}

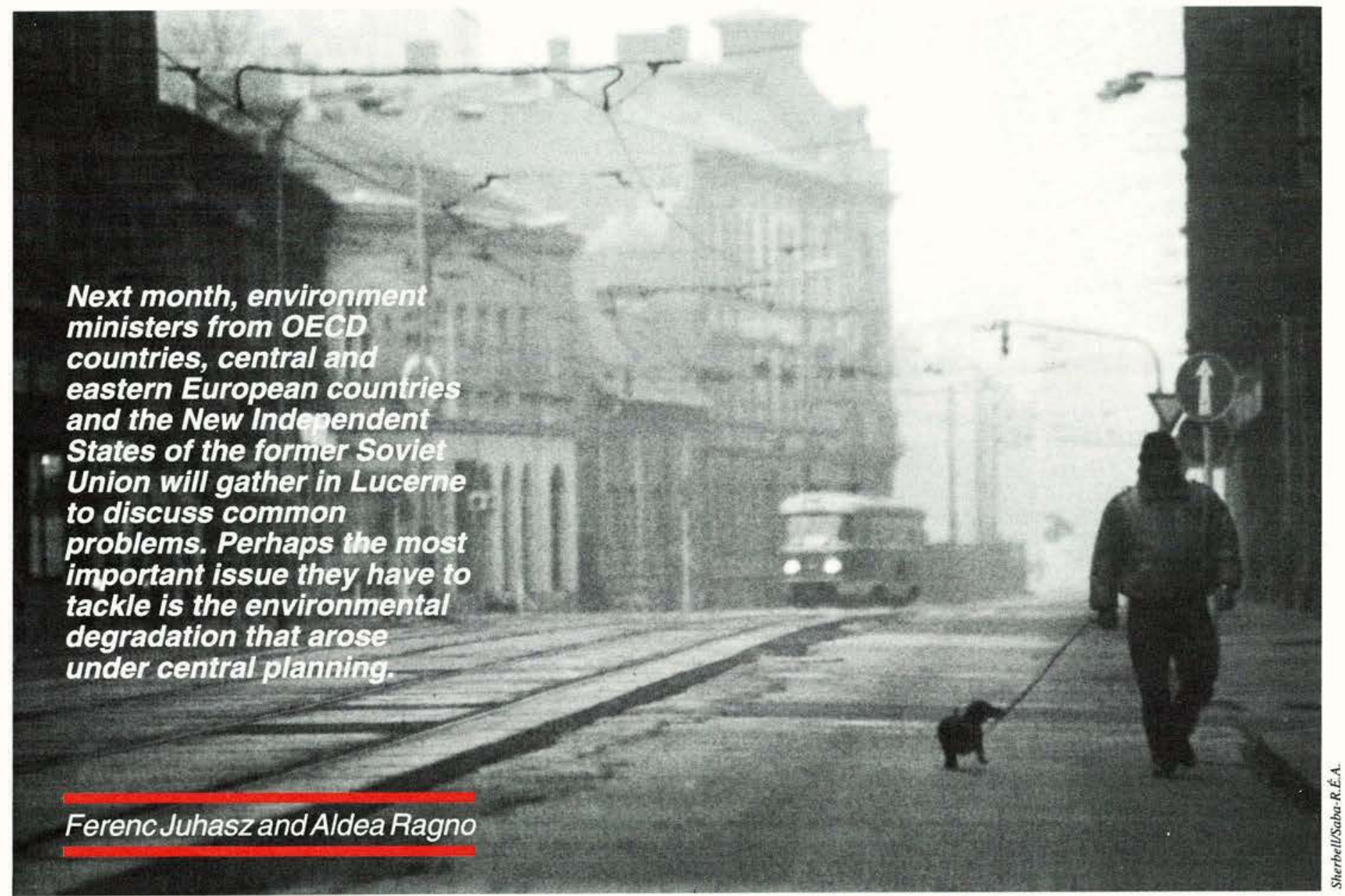

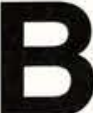

efore the advent of perestroika in 1985 , there was - officially no environmental degradation on any scale in what were then the centrally planned economies of the central and eastern European countries (CEECs) and the Soviet Union. According to conventional Marxist dogma, the main task of the state was to ensure the welfare of its citizens; and since the state also owned all factors of production, by definition it could not diminish welfare through environmental degradation. Then, in the 1970s and ' 80 s, responding to the growing importance of environmental policy in the West, nearly all these countries adopted new environmental laws. The subsequent fall of communism revealed the extent of environmental problems they face.

Assessing environmental 'quality' is difficult in the best of circumstances. Reliable time-series for individual countries are not easy to come by, and international comparisons can be distorted by differing standards and measurement techniques. These problems are particularly severe when considering conditions in the CEECs and the New Independent States of the former Soviet Union (NIS). Nevertheless,

1. Environmental Indicators: A Preliminary Set, OECD Publications, Paris, 1991

Ferenc Juhasz is a consultant to the OECD Environment Directorate, where Aldea Ragno is a trainee. if the comparisons are limited to individual pollutants and to similar types of settlements - for example, major cities some initial appraisals can be made. Furthermore, some indicators now universally accepted allow a quick understanding of possible causes of environmental degradation and the impact on the population - such as air emissions of specific pollutants per capita or per unit of GDP, or the water quality of major rivers. ${ }^{1}$

Water and air quality appear poor if judged by the standards the CEECs and NIS set for themselves. But these standards are on the whole stricter than in western Europe. In comparisons with several western European cities - using 




EC standards - the air quality of selected capital cities does not seem so dire: for particulate matter (mainly smoke, ash, and dust), Prague and Bucharest are worse than Brussels or Frankfurt but better than Athens; for smoke, Budapest is one of the least polluted cities in Europe, and Warsaw is better than Madrid or Athens. Budapest, like Frankfurt, exceeded EC standards for intermittent maximum concentration of sulphur dioxide ( $\mathrm{SO}_{2}$ ) over 1985-7; Warsaw and Bucharest were below it.

The data indicate nonetheless that these central and eastern European capitals do have real problems of air pollution. Moreover, there is evidence that in cities and other industrial centres throughout the region it substantially affects human health.

Industrial areas produce a lot of air pollution, particularly in socialist countries where heavy industries tended to be clumped together. For decades, factories there pumped large quantities of toxic fumes into the air - especially where they relied on poor-quality coal for energy. Average concentrations of black smoke around the industrial cities of Katowice and Kraków in Poland, for example, are about twice as high as in Warsaw and well above EC standards. In the Czech Republic, maximum concentrations of sulphur oxides in the northern Bohemian industrial complexes, fuelled by high-sulphur coal, occasionally reached the highest figures reported anywhere - even higher than Xian in China, reputed to be the worst place in the world for general air quality. Hungary as a whole, by contrast, has better air-quality in its industrial regions, which generally have a lower share of heavy industry, and rely less on coal for power, than industrial regions in Poland and the former Czech and Slovak Federal Republic (CSFR).
In addition, total national air emissions are high per unit of GDP. Poland and twice the concentration of nitrogen oxides $\left(\mathrm{NO}_{\mathrm{x}}\right.$ ) emissions per unit of GDP than most OECD countries. These countries produced at least four to five times as much sulphur oxide $\left(\mathrm{SO}_{\mathrm{x}}\right)$ emissions as OECD countries. These comparisons are at best approximate, because of the difficulties involved in comparing economic data between socialist and market economies. ${ }^{2}$

Assessing water quality is even more difficult than with air quality, with the technical problems compounded by the lack of recent comparative data. Comparisons of river quality for the mid-1980s suggest that the Danube and the Tisza in Hungary are significantly cleaner of faecal bacteria than the Rhine in the Netherlands or the Tejo in Portugal. But throughout the CEECs and NIS there are reports of extensive contamination of both freshwater and groundwater. For example, large-scale discharges of saline water from coal mines severely polluted Poland's major rivers.

Waste disposal was another major problem, especially for industrial waste waste per unit of output was higher and generally more toxic than in OECD countries, and disposal was inefficient and often illegal. Industrial waste dumps in the CEECs and NIS are now a sad legacy of central planning and a major problem for the new governments. In contrast, household waste was, until recently, a lesser problem than in the West. Packaging, for example, came in the form of low-grade paper or was immediately recycled between retailers and consumers for re-use. The same was true of glass, and there were few canned drinks available. Overall, there simply was less for households to consume, and therefore less waste. the former CSFR, for example, created
The effect of industrial concentration in heavy industry is made worse by its geographical concentration.

Degradation of land and losses of biological resources, with some limited exceptions, have not been worse than in OECD countries. There are reports of widespread soil erosion in Poland, Hungary, and the former CSFR, but the problems appear to be much less severe than in OECD Mediterranean countries. On the other hand, forest damage appears to be high, particularly in Poland, the Czech Republic and the Slovak Republic, where acid deposition has been high.

\section{The Cost of Degradation}

Economic losses from environmental degradation can come from a wide range of problems, each of which is difficult to estimate: agricultural losses from erosion, pollution of crops, soil acidification, waterlogging; decline in fish stocks; industrial losses through corrosion of materials, and the cost of treating inputs of contaminated water; damage to buildings from acid deposition; loss of timber through damage to forests; drops in revenue as tourist attractions become less popular.

One central question is the cost in terms of human health: evaluating health damage due to environmental causes is difficult and the results are always debatable. There are indications that pollution has caused significant health problems in the CEECs and NIS. In highly polluted Upper Silesia in Poland, for example, residents have $155 \%$ more circulatory illnesses, 30\% more cancer and $47 \%$ more respiratory illnesses than the national average. It is believed that increases in pollution have contributed to the fall in life-expectancy for middle-aged Polish men since the 1950s, a group that suffers from high mortality rates (women less so) in Hungary too. In the former CSFR - as in a number of countries in the region - male mortality increased in the 1970s and ' 80 s, and pollution is suspected to be one of the causes. In addition, high rates of a

2. Derek Blades, 'The Statistical Revolution in Central and Eastern Europe', The OECD Observer, No. 170, June/July 1991. 




number of illnesses, including acute respiratory diseases, have been documented in severely polluted areas of the former CSFR, as well as in other countries.

\section{Economic Causes of Environmental Decline}

Three main economic factors contributed to environmental degradation in the socialist economies: their industrial profile, energy practices, and the degree of infrastructural investment for the environment.

The economies of the CEECs and NIS focused heavily on industrial development. By recent estimates the industrial sector accounted for $35-65 \%$ of GDP, agriculture $5-35 \%$ and services $20-50 \%$ (in the advanced industrial countries of the OECD, by contrast, the distribution is around $30-40 \%$ for industry, over $55 \%$ for services and less than $10 \%$ for agriculture). This imbalance was exacerbated by the concentration of the industrial base in heavy industries (such as metallurgy, cement, bulk chemicals) that consume high quantities of energy and materials. In addition, most factories in the region are still based on production processes that are out-of-date, energy-intensive, and highly polluting compared to production methods now common in OECD countries.

High amounts of energy production and consumption are the second major source of pollution. On the basis of per capita consumption there is little difference between OECD countries and the CEECs and NIS. But industrial energy intensity is five times higher in Poland than in the United States, ${ }^{3}$ and a similar difference can be measured between Hungary and Germany; the economies of the Czech and Slovak Republics, too,

3. Stephen Perkins, 'Energy Policies for Poland'. The OECD Observer, No. 170, June/July 1991. are eight times more energy-intensive than Italy. Low energy prices are a principal reason for such high energy use. In addition, countries such as Poland and the former CSFR relied heavily on indigenous coal, often low-quality grades with high sulphur content, thus exacerbating pollution. The percentage share of coal in electricity generation is twice as high in Poland, the Czech Republic and the Slovak Republic as in Spain or Germany; it is even higher for industrial energy production. Coal also continued to be used in these countries for residential heating, a practice that created a large share of urban air pollution. The safety of nuclear-energy installations is another major source of concern. Indeed, the only bright spot is the relatively low energy-intensity of the transport sector, where private vehicles were few and energy-efficient public transport predominated.

The emphasis on heavy industrialisation contributed to the neglect of public environmental infrastructure, such as water-, sewerage- and waste-treatment plants. On the whole, the provision of these services is not worse than, for example, in the Mediterranean countries of the OECD although, with the exception of Poland, they have no coastal 'sink' into which to discharge their waste in any case, hardly a desirable activity.

\section{Why
the Policy Failure?}

In most socialist countries, the basic elements for environmental policy were in place. An administrative framework had been established. Laws and regulations were passed. A reporting and monitoring framework existed. An enforcement mechanism with charges and penalties had been created. And yet not only were official environmental stand-
For smoke, Budapest is one of the least polluted cities in Europe.

ards exceeded by far - not surprising in view of the strictness of the standards - but there are few indications that pollution and environmental damage decreased. What went wrong?

First, governments failed, on a massive scale, to co-ordinate environmental and economic policies. Production quotas were always the most important goals, despite environmental costs and other problems. Under central planning, the low prices set for raw materials, energy, and agricultural inputs more than counteracted any environmental measures. And the citizens paid three times: in subsidies, in damage to the environment and health, and, where attempts were made to reduce pollution, through the costs of pollution control.

Second, governments failed to enforce their policies. Environment authorities, particularly local ones, lacked the authority over large state enterprises in their regions, particularly when they were the only employers. Fines were ineffective because the enterprises did not have to pay attention to costs - they faced no threat of bankruptcy, and could cover any pollution fines or charges with state credits and subsidies. Plants were often old and inefficient, and fitting them with anti-pollution devices would have been expensive and ineffective.

Finally, the public had no way of protesting over environmental problems and demanding better government responses. Indeed, most environmental data were state secrets. With the opening-up of these societies that came in the late 1980s, in fact, environmental movements were among the first organised protest movements, and they played an important role in the fall of socialist regimes in Poland, Hungary, the former CFSR, Bulgaria, and in the independence movements of the Baltic Republics.

\section{Which Way Forward?}

With the fall of communism, the new democratic governments have their hands full with the economic issues and problems of the transition to market economies. Public concerns have shifted to 




problems like falling production and rising unemployment. Environmental issues are no longer centre-stage.

Nonetheless, environmental problems are still important for the transition. First, many of them have to be solved, although current government budget difficulties limit funds even for urgently required infrastructure projects such as sewageand water-treatment works. These budgetary pressures also hamper the development of environmental policies adapted to the transition, and the installation of the mechanisms necessary to administer environmental requirements in a market-based economy. As countries in the region return to economic growth, some problems will worsen, such as air pollution and congestion from the increasing number of private automobiles.

Second, governments in the region have to consider environmental issues in close co-ordination with economic and industrial policies for the transition. Industrial restructuring and other changes will have important implications for the environment. Higher energy prices and market competition should improve

Low energy prices combined with low-quality coal combine to exacerbate pollution.

energy efficiency and, in the long term, a restructuring of industrial sectors away from heavy industry. Higher prices will also encourage more efficient energy use by households. These trends should, in particular, reduce air pollution from electricity based on fossil fuels and from industrial plants. At the same time, as viable plants modernise and invest in new equipment, governments can use regulatory and economic instruments to encourage a 'clean transition'. Environmental and economic problems are very often related. For instance, many large industrial enterprises that are now being privatised may lack resources to invest in either pollution-control equipment or new, more efficient and less polluting processes. The integration of policies can help resolve such difficulties.

From the beginning of the transition process, OECD countries have provided a wide range of assistance to the countries of central and eastern Europe, through both bilateral programmes and multilateral organisations. For the environment, this assistance has provided technical and administrative experience, the training of personnel, the transfer of technologies, and loans and grants for major projects. Many of these initiatives include the private sector and environmental groups. These programmes are important not only in the form of direct assistance they provide. In many cases they also offer seed money and generate further efforts on the part of the governments themselves.

The environmental problems of the CEECs and NIS are a key international concern, for at least two reasons. First, pollution does not respect boundaries, whether it is acid rain from coal combustion, water pollution that flows into the Black Sea and Baltic Sea from discharges into rivers, or emissions of greenhouse gases. Second, and at least as important, resolving the region's environmental problems has to be part of the transition to democratic, market-based systems.

\section{드.}

The 'Environment for Europe' Ministerial Conference next month in Lucerne is an important stage in the process of environmental co-operation between OECD countries, the CEECs and NIS; it is the follow-up to a conference held in June 1991 near Prague, and hosted by President Vaclav Havel. At Lucerne, ministers will focus on two themes a long-term Pan-European Environment Strategy, and an Environmental Action Programme for the CEECs and NIS.

Ministers will discuss a variety of difficult issues concerning the environmental problems in the CEECs and NIS. How should limited domestic funds and international assistance be best targetted? What are the key problems that require assistance? How can domestic policies and international assistance better be co-ordinated? How can environmental issues be best tackled during the economic transition to promote 'cleaner growth'? Their answers to these questions will, it is hoped, encourage environmental improvements throughout Europe, and in particular in the countries in transition.

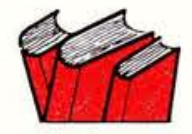

\section{OECD Bibliography}

- Environmental Information Systems and Indicators: A Review of Selected Central European Countries, CCEET/OECD, forthcoming 1993

- Energy and Environment in European Economies in Transition, IEAVOECD, 1993

- Antonella Bassani, 'Steppes to a Market Economy', The OECD Observer, No. 180, February/March 1993

- OECD Economic Surveys: The Czech and Slovak Federal Republic, CCEET/OECD, 1992

\section{- OECD Economic Surveys:}

Hungary, CCEET/OECD, 1991

- Stephen Perkins, 'Energy Policies for Poland', The OECD Observer, No. 170 , June/July 1991

- Christian Avérous, 'An Uneven Track Record for the Environment', The OECD Observer, No. 168, February/March 1991. 

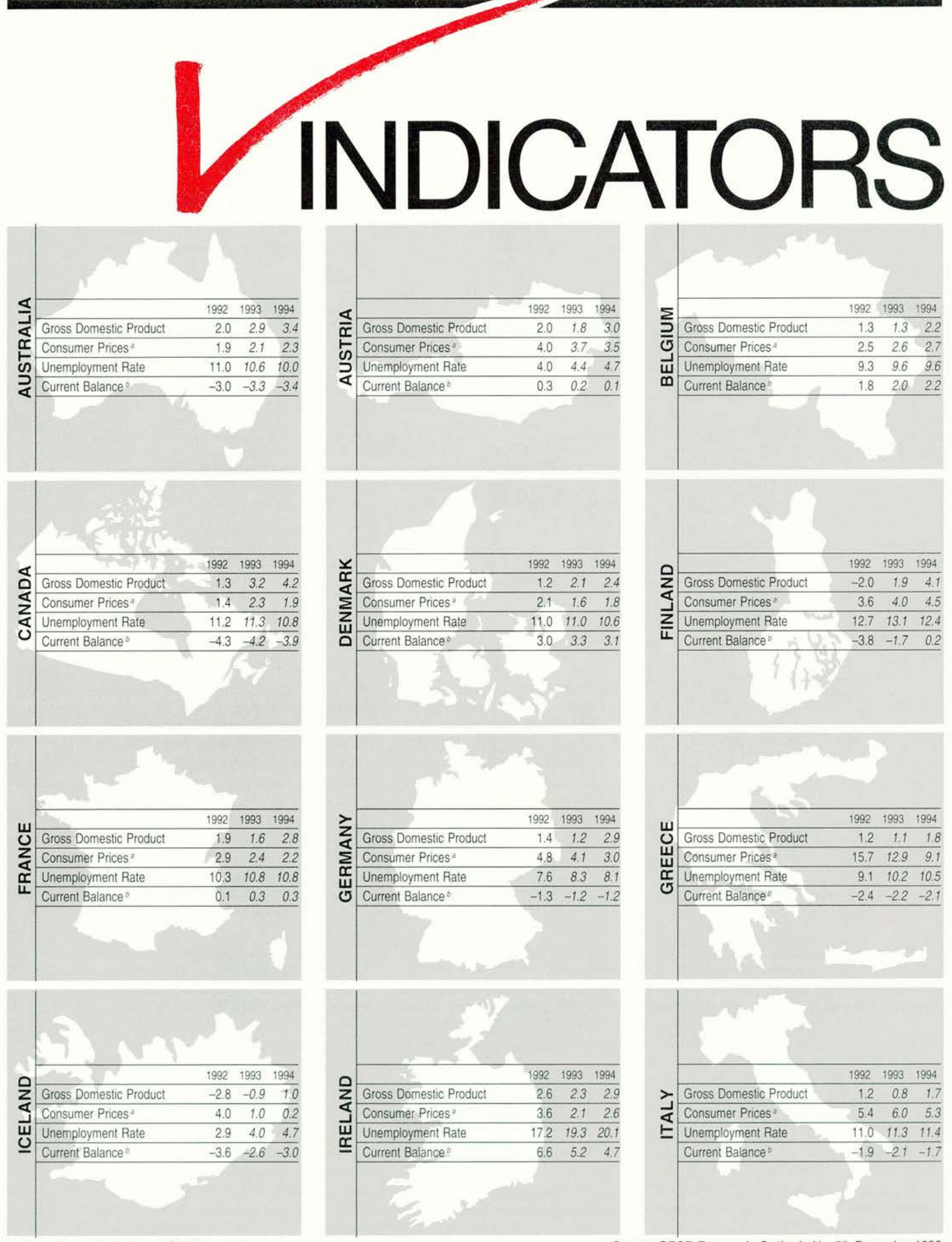

Notes: Figures in italics are OECD projections a. Private consumption deflator

b. Current balance as \% of GDP (GNP for Turkey)

Source: OECD Economic Outlook, No. 52, December 1992 for further information, contact The OECD Observer 


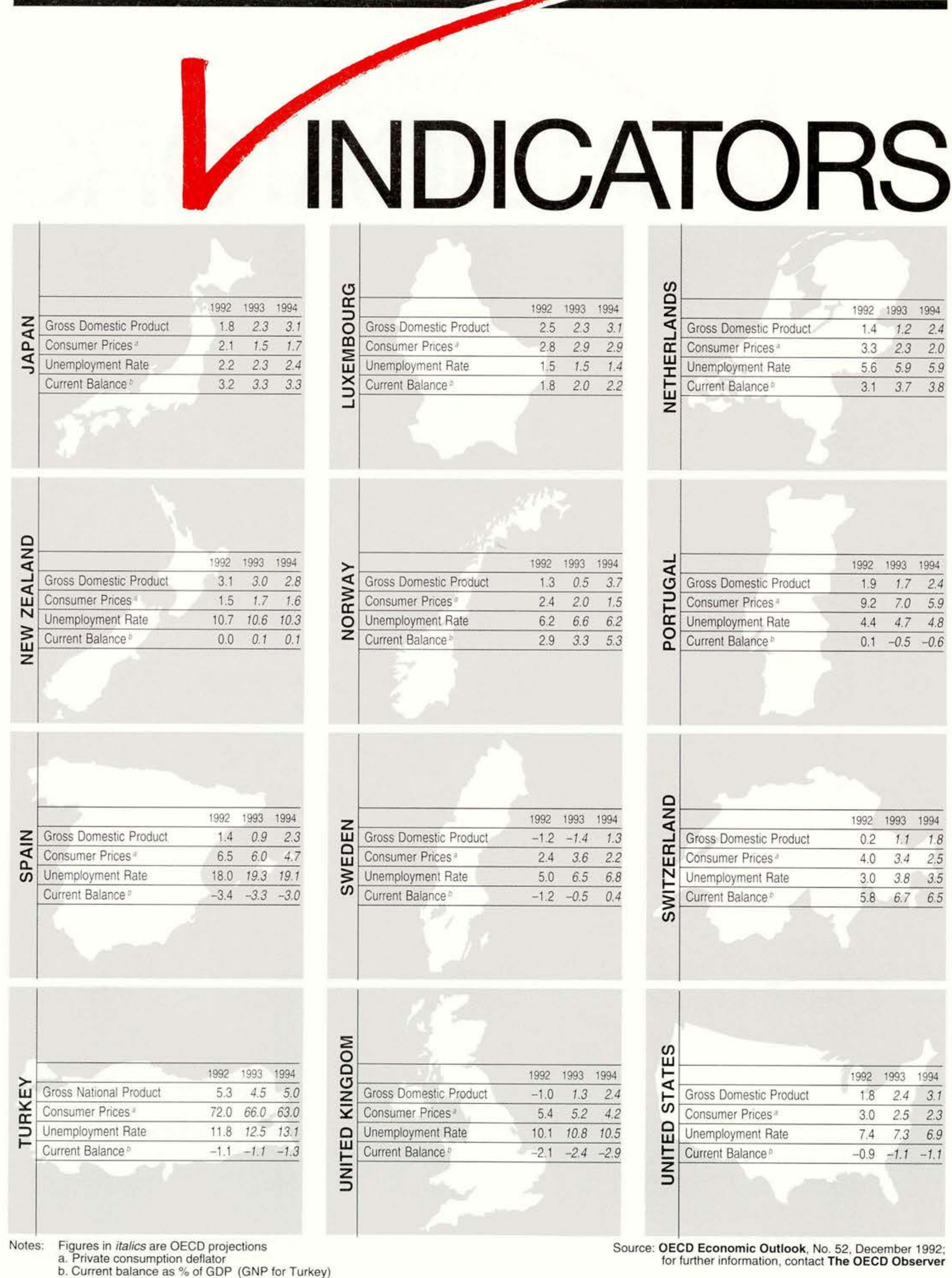




\section{Gale \\ New OECD Publications}

SUE • FILL IN THE FORM WITH THIS ISSUE • FILL IN THE FORM WITH THIS ISSUE • FILL IN THE FORM WITH THIS ISSUE • FILL IN T

Economy
OECD Economic Surveys
1992-1993 Series
UNITED KINGDOM
(January 1993)
(10 93 28 1) ISBN 92-64-13816-1, 121pp.
DENMARK
(February 1993)
(10 93 13 1) ISBN 92-64-13831-5, 150pp.
NEW ZEALAND
(February 1993)
(10 93 05 1) ISBN 92-64-13817-X, 150pp.
Per issue: FF80 £11 US\$20 DM30
$1992-1993$ Subscription:
(17 to 19 Surveys to be published)
(10 00 00 1) ISSN 0376-6438
FF950 £110 US\$195 DM360

OECD Economic Studies

No. 19 Winter 1992

Special issue:

The Economic Costs

of Reducing $\mathrm{CO}_{2}$ Emissions (February 1993)

See Tom Jones, 'The Economics of Climate Change', The OECD Observer, No. 179, December 1992/January 1993.

(13 9219 1) ISBN 92-64-13828-5, 216pp.

FF120 £15 \$25 DM47

\section{'National Accounts:}

Sources and Methods' Series

METHODS USED BY OECD COUNTRIES

TO MEASURE STOCKS

OF FIXED CAPITAL

(January 1993) Bilingual

(30 9208 3) ISBN 92-64-03708-X, 68pp.

FF95 £14 US\$26 DM39

\section{Centre for Co-operation with European Economies in Transition}

REGIONAL DEVELOPMENT

PROBLEMS AND POLICIES IN POLAND (January 1993)

Until now regional disparities in Poland have been relatively moderate, but the process of transition to a market economy is leading to disparities in income levels, industrial mix, infrastructure and employment. This study examines the legacy of forty years of central planning, reviewing recent changes introduced by the new democratic govemments, regional disparities and regional policy objectives and instruments.

(14 92 03 1) ISBN 92-64-13807-2, 84pp. FF60 ₹10 US\$15 DM25

\section{SHORT-TERM ECONOMIC INDICATORS Central and Eastern Europe \\ No. 1 February 1993 Bilingual}

This quarterly publication complements the OECD Main Economic Indicators. It presents a wide range of monthly, quarterly and annual economic indicators for five countries of central and eastern Europe: Bulgaria, the Czech and Slovak Federal Republic, Hungary, Poland and Romania.

The indicators selected cover such topics as industrial production, construction, employment, earnings, prices, domestic and foreign finance, interest rates and domestic and foreign trade. (07 9301 3) ISBN 92-64-03710-1, 40pp. Per issue: FF40 £5 US\$9 DM16 1993 Subscription: FF120 £16 US\$28 DM52 Available on diskette

\section{Agriculture \\ and Fisheries}

AGRICULTURAL AND ENVIRONMENTAL POLICY INTEGRATION

Recent Progress and New Directions

(February 1993)

(97 9211 1) ISBN 92-64-13820-X, 100pp.

FF100 ₹17 US\$24 DM41

\section{REVIEW OF FISHERIES}

IN OECD MEMBER COUNTRIES

(January 1993)

The annual review of the OECD Committee for Fisheries describes major developments affecting the commercial fisheries of OECD countries, including government policy and action, and developments in production, processing, marketing and international trade.

1990 was marked by growing concern about the marine environment and conservation of marine resources, which led to further reductions in quotas on certain types of fish, and action at the international level to limit or stop certain fishing practices.

International trade in fish products exceeded the previous year's levels in both quantity and value. National fishing fleets and downstream processing activities continued to undergo restructuring in most OECD countries in an effort to adjust to declining fish stocks and more limited access to resources.

This edition also contains a special survey on Poland.

(53 9201 1) ISBN 92-64-13810-2, 340pp.

FF400 £52 US\$96 DM156

\section{Development}

\section{'Development Centre Documents'}

Series

ENVIRONMENTAL EDUCATION

\section{An Approach}

to Sustainable Development

Edited by Hartmut Schneider with Jacoline Vinke and Winifred Weekes-Vagliani

(January 1993)

Environmental education is gaining increasing importance because conventional regulatory approaches to environmental protection face serious difficulties if decision-makers and the population at large lack knowledge, skills and motivation to promote environmentally sound management. This report, drawing on a Development Centre workshop held in April 1992, includes 10 case studies of educational programmes in Africa, Asia and Latin America which are designed to promote sustainable development. These studies are complemented by overviews of experiences in selected OECD countries and in a large number of developing countries. The report outlines requirements for more effective environmental education and advocates an action-oriented, locally-adapted approach. (02 9216 1) ISBN 92-64-13771-8, 260pp.

FF110 £18 US\$30 DM45

\section{Education}

FROM HIGHER EDUCATION

TO EMPLOYMENT Synthesis Report

(February 1993)

A fresh look is being taken at the link between higher education and employment, because education is considered nowadays a strategic resource, and the spread of technological progress is generating a demand for increasingly higher professional qualifications. At the same time, certain categories of graduates are still unable to obtain employment, or have to accept to be downgraded to less qualified jobs.

Four volumes, published in the series of 'OECD Documents', gather together all of the data available in OECD countries at the end of 1990 on flows of graduates from higher education and their entry into employment. From the conceptual standpoint, each country has done its best to assemble and present the data in such a way that a comparison of outflows from higher education and inflows into working life can be made - though the differences in approach and philosophy from one country to another are plain.

Volume I: Australia, Austria, Belgium, Germany Volume II: Canada, Denmark, Spain, United States Volume III: Finland, France, Italy, Japan, Netherlands, Norway

Volume IV: Sweden, Switzerland, United Kingdom

This report analyses this information, summarises the issues and endeavours to identify the main challenges for the 1990s.

See Eric Esnault, 'From Higher Education to Employment', The OECD Observer, No. 176, June/ July 1992

(9192 05 1) ISBN 92-64-13825-0, 152pp.

FF140 £23 US\$33 DM57

\section{Energy}

\section{IEA (International Energy Agency)}

CONFERENCE ON ENERGY

AND ENVIRONMENT

IN EUROPEAN ECONOMIES

IN TRANSITION

Prague Proceedings

(December 1992)

(61 9304 1) ISBN 92-64-13813-7, 256pp.

FF220 £36 \$53 DM90

\section{ENERGY POLICIES}

\section{OF THE REPUBLIC OF KOREA}

(January 1993)

This report analyses the energy sector and related energy policies of the Republic of Korea. It is the first in-depth IEA review of a non-member country in the Asia-Pacific region. The study examines the current energy supply and demand situation by sector, as well as the overall energy outlook to 2010. Energy-efficiency and the environmental implications of energy use are also considered. The report develops a series of policy recommendations gauged to enable the Korean government both to achieve its energy security and environmental objectives, and to reduce the traditionally high extent of intervention in the energy sector. The IEA conducted this survey in May 1992, with the co-operation and support of the Korean government.

(61 9219 1) ISBN 92-64-13805-6, 156pp.

FF160 £26 US\$38 DM64

\section{TAXING ENERGY}

\section{Why and How}

(January 1993)

This study reviews the energy tax regimes of selected OECD countries and explores why 
energy is taxed, if present regimes might be employed for new uses, and how effective energy taxes might be at achieving aims other than raising revenues. The study begins by comparing five OECD countries with different tax regimes, energy mixes and pollution burdens: Australia, Denmark, Germany, Japan and the United States. It high lights issues faced by governments considering new energy taxes as a way to affect energy consumption and energy-related pollution.

(6193011) ISBN 92-64-13806-4, 152pp.

FF170 \&29 US\$39 DM70

\section{'Energy and Environment' Series} CARS AND CLIMATE CHANGE

(January 1993)

The OECD transport sector produced nearl y three times as much carbon dioxide in 1990 as it did in 1960. Most of the increase came from cars. This study analyses trends in greenhouse-gas emissions from cars and the opportunities for abatement. The report examines the potential for emission reductions, through fuel-economy and altemative fuels. It compares overall greenhouse-gas emissions, the state of technical development and the associated costs. Market niches are identified where alternative fuels may be cost-effective in the year 2000. Several case studies illustrate strategies to promote fuel-economy and alternative fuels. The study explores ways in which governments could improve their analysis of the options. (61 9302 1) ISBN 92-64-13804-8, 350pp. FF250 £43 US\$60 DM100

\section{NEA (Nuclear Energy Agency)}

\section{'Safety' Series}

THE SAFETY

OF THE NUCLEAR FUEL CYCLE

(February 1993)

The nuclear fuel cycle covers the procurement and preparation of fuel for nuclear power reactors, its recovery and recycling after use and the safe storage of all wastes generated through these operations. The facilities associated with these activities have an extensive and well documented safety record accumulated over the past 40 years by technical experts and safety authorities. This report constitutes an up-to-date analysis of the safety of the nuclear fuel cycle, based on the available experience in OECD countries. It addresses the technical aspects of fuel cycle operations, provides information on operating practices and looks ahead to future activities.

(66 9217 1) ISBN 92-64-13824-2, 248pp.

FF280 \&47 US $\$ 65$ DM115

'Radiation Protection' Series

WORK MANAGEMENT

TO REDUCE OCCUPATIONAL DOSES

Proceedings of an NEA Workshop

Paris, 4-6 February 1992

(February 1993) Bilingual

(66 9209 3) ISBN 92-64-03712-8, 344pp.

FF290 £48 US\$70 DM119

\section{Finance}

TAXATION IN OECD COUNTRIES

(February 1993)

Drafted in a clear and concise style that opens a complex subject to everyone, this report provides an exhaustive inventory of the tax measures in force in 1990 in the OECD countries. It deals in turn with personal income taxes, corporate income taxes, value-added taxes, and taxpayers' rights and obligations.

This detailed review of taxation and recent tax reforms in the OECD countries will be an excellent reference manual for all those, specialists orlaymen, who wish to perfect or increase their knowledge of the subject.

With 53 tables and 3 graphs

(23 9301 1) ISBN 92-64-13815-3, 116pp.

FF90 £15 US\$36 DM22

TAX ASPECTS OF TRANSFER PRICING WITHIN MULTINATIONAL ENTERPRISES The United States Proposed Regulations (January 1993)

(02 9301 1) ISBN 92-64-13821-8, 80pp.

FF40 £7 US\$9 DM16

PURCHASING POWER PARITIES

AND REAL EXPENDITURES

FOR CANADA

AND THE UNITED STATES 1990

(February 1993) Bilingual

This publication is one of three regional comparisons published in 1992 and 1993 based on price and expenditure data for the new benchmark year 1990

This volume covers a bilateral comparison of these two countries.

(30 9302 3) ISBN 92-64-03711-X, 60pp.

FF70 $₹ 10$ US $\$ 18$ DM30

'Issues in International Taxation' Series No. 4: MODEL TAX CONVENTION

Four Related Studies

(December 1992)

This publication includes four recent reports of the OECD that have resulted in changes to the Commentary of the Model Tax Convention on Income and on Capital. These studies deal with the computation of the 183 day rule of sub-paragraph $2 \mathrm{~b}$ ) of Article 15 of the Model, the application of tax conventions to so-called 'triangular cases', the tax treatment of software payments and the tax treatment of employees' contributions to foreign pension schemes.

(23 9203 1) ISBN 92-64-13801-3 104pp.

FF100 £17 US\$24 DM4

\section{Centre for Co-operation with European} Economies in Transition

\section{VALUATION AND PRIVATISATION}

(January 1993)

Valuation is a prerequisite for successful privatisation. Privatisation agencies have to determine fair value to support their negotiations with investors and to justify the sales price after reaching an agreement. Investors will use valuations to determine a risk-adjusted price which will allow them to achieve the desired level of profitability.

This volume reviews development in accounting and valuation. Based on recent experience in central and eastern European economies, it discusses the main methods of asset and business evaluation and their application in a period of transition and economic uncertainty.

(14 9302 1) ISBN 92-64-13818-8, 120pp.

FF100 \&17 US\$24 DM40
'10 BESTSELLERS'

(To order, please use the form inserted in this issue)

1. OECD ECONOMIC OUTLOOK No. 52

(12 9252 1) ISBN 92-64-23792-5 FF110 $\$ 13.50$ US\$24.00 DM43

2. OECD Economic Surveys 1991-1992 Series

JAPAN

(10 9203 1) ISBN 92-64-23773-9

FF70 $£ 10.00$ US\$18.00 DM27

3. OECD Economic Surveys 1991-1992 Series UNITED STATES

(10 9202 1) ISBN 92-64-23775-5 FF70 $£ 10.00$ US\$18.00 DM27

4. DEVELOPMENT ASSISTANCE MANUAL

DAC Principles for Effective Aid

(439206 1) ISBN 92-64-23779-8 FF75 12.00 US\$19.00 DM31

5. DEVELOPMENT CO-OPERATION Efforts and Policies of the Members of the Development Assistance Committee 1992 Report

(439205 1) ISBN 92-64-23772-0 FF160 £19.00 US\$34.00 DM65

6. EXTERNAL DEBT STATISTICS

The Debt and Other External

Liabilities of Developing, Central and Eastern European and Certain Other Countries and Territories at End-December 1991 and End-December 1990 (43 9204 1) ISBN 92-64-23766-6 FF95 $£ 14.00$ US\$26.00 DM39

7. U.S. HEALTH CARE AT THE CROSS-ROADS (11 9203 1) ISBN 92-64-23780-1 FF60 $\$ 15.00$ US\$9.00 DM25

8. URBAN POLICIES FOR AGEING POPULATIONS

(97 9203 1) ISBN 92-64-23758-5 FF150 £22.00 US\$37.00 DM60

9. THE REFORM OF HEALTH CARE A Comparative Analysis of Seven OECD Countries

(81 92021 ) ISBN 92-64-23791-7 FF180 £30.00 US\$46.00 DM74

\section{INDUSTRIAL POLICY} IN OECD COUNTRIES Annual Review (70 9205 1) ISBN 92-64-23765-8 FF150 £21.00 US\$37.00 DM61 


\section{METHODS OF PRIVATISING}

\section{LARGE ENTERPRISES}

(January 1993) Bilingual

Policy-makers in central and eastern Europe face extraordinary challenges when undertaking large-scale privatisation programmes. This report focuses on the major practical dimensions of the privatisation of large enterprises: the scope of privatisation, steps taken before privatisation, accounting and valuation issues, modalities of privatisation, financial-market aspects, the legal and institutional framework, the influence of the macro-economic situation, and the social and political dimensions.

This volume, one of a series devoted to problems faced by central and eastern European countries, is intended to add to the understanding of the problems that policy-makers there have to address in designing and implementing policies for the privatisation of large enterprises.

(149207 3) ISBN 92-64-03709-8, 208pp. FF150 \&26 US\$36 DM62

\section{Public Management}

\section{PUBLIC MANAGEMENT}

OECD Country Profiles

(January 1993)

Designed as a reference manual, this compendium provides a systematic collection of information on the principal public institutions in 22 OECD countries. For each country it describes key central government bodies as well as those of the legislative and judicial authorities and sub-national governments. It also includes some supportive statis tical data on public sector structures.

The country profiles show the diversity of administrative systems in mid-1992 in a group of the world's most economically advanced market-based democracies. The compendium is designed to help readers understand and compare the contexts within which public management reforms are currently taking place.

(42 9301 1) ISBN 92-64-13809-9, 370pp.

FF35 \&58 US\$80 DM140

'Public Management Studies' Series PRIVATE PAY FOR PUBLIC WORK

Performance-related Pay

for Public Sector Managers

(February 1993)

Elected officials and public managers in many OECD countries support performance-related pay as an alternative to the traditional notion of seniority or job level to determine individual salaries. And there is evidence that properly implemented schemes can contribute to improvements in public sector management. Nevertheless, as this report shows, there are problems with performance pay schemes. Among other things, there is a lack of rigorous evaluation, which makes it difficult to determine their impact on efficiency.

As public service shifts toward a stronger performance orientation, this report provides an invaluable look at some of the problems and their solutions.

See Maria Maguire and Robert Wood, 'Private Pay for Public Work?', The OECD Observer, No. 175 , April/May 1992

(42 9202 1) ISBN 92-64-13823-4, 236pp.

FF120 £20 US\$28 DM49

\section{Rural Development}

WHAT FUTURE

FOR OUR COUNTRYSIDE?

A Rural Development Policy

(January 1993)

The rural world - one third of the population and nine tenths of the territory of OECD member countries-is going through a period of profound change. Some areas are developing rapidly while others are faced with constant decreases in population. Agricultural policy concerns only a small, shrinking proportion of rural dwellers and economies. Recognition that the rural world plays an important role in the vital societal balance between town and country is growing

This report provides a reference guide through the complex territorial and multi-sectoral dimensions of rural development, illustrated by a variety of examples from OECD countries. After analysing the problems and potentials of rural areas, the report offers a policy framework with clearly defined rural development objectives and the challenge of meeting them.

See Christian Huillet and Richard Long, 'Policy Issues in Rural Development', The OECD Observer, No. 178, October/November 1992.

(039302 1) ISBN 92-64-13808-0, 84pp. FF80 ₹14 US\$20 DM33

\section{Science, Technology and Industry}

\section{ICCP 'Information, Computer and} Communications Policy' Series

No. 31: USAGE INDICATORS

A New Foundation for Information

Technology Policies

(January 1993)

Although statistical reporting of production and sales of information technology-based goods and services and the performance of the Information Technology industry has improved, new tools are necessary to determine how IT is actually used. This book puts forward the development of IT usage indicators - measurements which capture the quantitative and qualitative impacts of IT in private and public sector applications.

Usage indicators can provide insight into such issues as:

- how IT is used in various economic sectors and what are the economic or social results

- how many people actually work with computers and other IT and what effect IT has on their work - how and why IT usage differs among economic sectors and countries.

This report presents a new approach to such issues and provides detailed information of IT usage and emerging trends in OECD countries.

(9393 01 1) ISBN 92-64-13814-5, 132pp. FF100 117 US 24 2M41

\section{STI SCIENCE TECHNOLOGY} INDUSTRY REVIEW

No. 11

(December 1992)

Innovation and the application of new technologies have moved into the centre of enterprise strategies and are an increasing focus of govemment poli- cies. However, very little quantitative data is collected on either. This issue of the STI Review draws on a wider range of sources than usual to present the results of recent national surveys of innovation. The results of national innovation surveys are presented for France, Germany, Italy, the Netherlands, Norway and Sweden.

This publication, which appears twice yearly, contains reports and articles on science, technology and industry policy.

909211 1) ISBN 92-64-13811-0, 138pp.

FF110 $£ 13.50 \$ 23.50$ DM45

\section{Transport}

INTERNATIONAL AIR TRANSPORT

The Challenges Ahead

(February 1993)

See Michel Andrieu, "What Horizons for Air Transport?', The OECD Observer, No. 180, February/ March 1993.

(03 9301 1) ISBN 92-64-13797-1, 118pp.

FF120 \&21 US\$29 DM50

\section{MARITIME TRANSPORT 1991}

(February 1993)

International maritime trade movements reached a new record in 1991. Crude oil shipments increased slightly compared to 1990, and performance varied in the bulk trades. Once again liner trades were marked by good to almost full use of capacity in most of the world's main liner routes. Political and economic events again had a strong impact on world shipping developments but did not necessitate active governmental involvement in commercial shipping. On the contrary, OECD member countries directed their efforts to establishing a level playing field and maintaining a competitive framework within which the shipping industry could operate.

With 32 tables and 16 graphs

(76 9301 1) ISBN 92-64-13822-6, 152pp.

FF190 233 US $\$ 46$ DM79

\section{ECMT (The European Conference} of Ministers of Transport)

TRANSPORT GROWTH IN QUESTION

12th International Symposium

on Theory and Practice

in Transport Economics

(January 1993)

Given the continuous increase in personal mobility coupled with an increased awareness of the im portance of protecting the environment, there is clearly no doubt that the prospect of further growth in transport is open to question. But, despite this keener awareness and despite the severe damage already done to the environment, there would seem to be little sign of any reduction in the use of the private car in urban areas. Ways of resolving the problem do exist, but the authorities encounter resistance by the public to their acceptance.

This publication takes stock of the issues arising in connection with the growth of transport and the situation as regards the quality of life in general and in the process of examining both the sociological background and the technological resources available, outlines ways of coping with the difficulties. With 67 tables and 77 graphs 759301 1) ISBN 92-821-1180-6, 656pp. FF350 £58 US\$80 DM140 


\section{Where to obtain OECD Publications}

\section{FRANCE OECD \\ Mail Orders: \\ 2, rue André-Pascal \\ 75775 Paris Cedex 16 Tel. (33-1) \\ Teletax: $(33-1) 45.24 .82 .00$ or $(33-1) 45.24 .85 .00$ Telex: $640048 \mathrm{OCDE}$ \\ OECD Bookshop: \\ 33, rue Octave-Feuille

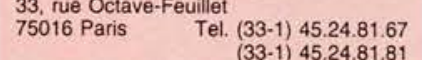 \\ GERMANY \\ OECD Publications and Information Centre \\ August-Bebel-Allee 6
D-W 5300 Bonn 2 Tel. (0228) 959.120 Telefax: (0228) 959.12.17 \\ JAPAN \\ OECD Publications and Information Centre \\ Landic Akasaka Building \\ 2-3-4 Akasaka, Minato-ku
Tokyo $107 \quad$ Tel. (81.3) 3586.2016 Telefax: (81.3) 3584.7929 \\ UNITED STATES \\ OECD Publications and Information Centre 2001 L Street N.W., Suite 700 Washington, D.C. 20036-4910 Tel. (202) Telefax: (202) 785.0350 \\ ARGENTINA \\ Carlos Hirsch S.R.L. \\ $\begin{array}{ll}\text { Galeria Güemes, Florida } 165,4^{\circ} \text { Piso } \\ 1333 \text { Buenos Aires } & \text { Tel. (1) } 331.1787 \text { y }\end{array}$ 331.2391}

AUSTRALIA

D.A. Information Services

648 Whitehorse Road, P.O.B 163

Mitcham, Victoria 3132 Tel. (03) 873.4411 Telefax: (03) 873.5679

AUSTRIA

Gerold \& Co

Graben 3

Wien I

Tel. (0222) 533.50 .14

BELGIUM

Jean De Lannoy

Avenue du Roi 202

B-1060 Bruxelles

Tel. (02)
$538.51 .69 / 538.08 .41$ Telefax: (02) 538.08.41

\section{CANADA}

Renouf Publishing Company Ltd.

1294 Algoma Road

Ottawa, ON K1B 3W8 Tel. (613) 741.4333 Stores: Telefax: (613) 741.5439

Stores:

61 Sparks Street

Ottawa, ON K1P 5R1. Tel. (613) 238.8985

211 Yonge Street
Toronto, ON M5B 1M4 Tel. (416) 363.3171

Les Éditions La Liberté Inc.

3020 Chemin Sainte-Foy

Sainte-Foy, PQ G1X 3V

$$
\text { Tel. + Telefax: (418) } 658.3763
$$

Federal Publications

165 University Avenue

Toronto, ON M5H 3B8 Tel. (416) 581.1552

Les Publications Fédérales

1185 Avenue de I'Université

Montréal, PQ H3B 3 A7

Tel. + Telefax : (514) 954.1633

CHINA

China National Publications Impor

Export Corporation (CNPIEC)

16 Gongti E. Road, Chaoyang District

Tel. (01) 506.6688 Telefax: (01) 506.3101

\section{DENMARK}

Munksgaard Export and Subscription Service

35. Nørre Søgade, P.O. Box 2148

DK-1016 København K Tel, (33) 12.85.70 Telefax: (33) 12.93 .87

FINLAND

Akateeminen Kirjakauppa

Keskuskatu 1, P.O. Box 128
FRANCE

See box above

Documentation Française

$\begin{array}{ll}\text { 29, quai Voltaire } & \text { Tel. (1) } 40.15 .70 .00\end{array}$

Gibert Jeune (Droit-Économie)

6 , place Saint-Michel

75006 Paris $\quad$ Tel. (1) 43.25 .91 .19

Librairie du Commerce International

10 , avenue d'léna

75016 Paris

Tel. (1) 40.73 .34 .60

Librairie Dunod

Université Paris-Dauphine

Place du Maréchal de Lattre de Tassigny

75016 Paris $\quad$ Tel. (1) 47.27 .18 .56

Librairie Lavoisier

11, rue Lavoisier

75008 Paris

Kyobo Book Centre Co. Ltd

Kyobo Book Centre Co. Ltd. Seoul

Editrice e Libreria Herder

Piazza Montecitorio 120

00186 Roma

Tel. (1) 42.65 .39 .95

Librairie L.G.D.J. - Montchrestien

20, rue Soufflot 75005 Paris $\quad$ MALAYSIA

Librairie des Sciences Politiques

30, rue Saint-Guillaume

75007 Paris

Tel. (1) 45.48 .36 .02

PUF

49, boulevard Saint-Michel

75005 Paris Tel. (1) 43.25 .83 .40

Librairie de PUniversité

12a, rue Nazareth

13100 Aix-en-Provence Tel. (16) 42.26.18.08

Documentation Française

165 , rue Garibald

69003 Lyon

Tel. (16) 78.63.32.23

Librine Decitre

69002 Lyon

Tel. (16) 72.40 .54 .54

GREECE

Librairie Kauffmann

Mavrokordatou

10678 Athens

Tel. 322.21 .60

HONG KONG

Swindon Book Co. Lid

13-15 Lock Road

Kowloon, Hong Kong

Tel. 366.80 .31

Libreria Hoepl

20121 Milano

Libreria Scientifica

Dott. Lucio de Biasio 'Aeiou'

Via Coronelli 6

Tel. (02) 48.95 .45 .52

ax: (02) 48.95 .45 .48

Co-operative Bookshop Ltd.

Tel. 730.78 .91

Telefax: 735.00 .30

University of Malay

P.O. Box 1127, Jalan Pantai Bar

59700 Kuala Lumipur

Malaysia

\section{Tel. $756.5000 / 756.5425$}

Telefax: 757.3661

MEXICO

Revistas y Periodicos Internacionales S.A. de C.V.

Florencia 57 - 1004

Tel. 207.81 .00 Telefax : 208.39.79

NETHERLANDS

SDU Uitgeveri]

Christoffel Plantijnstraat 2

Postbus 20014

2500 EA's-Gravenhage Tel. (070 3) 78.99.11 Voor bestellingen:

Tel. $(070$ 3) 78.98 .80 Telefax: (070 3) 47.63 .51

NEW ZEALAND

Legislation Services

P. Box 12418

Thorndon, Wellington Tel. (04) 496.5652

NORWAY

Narvesen Info Center - NIC

Bertrand Narvesens vei 2

P.O. Box 6125 Etterstad

HUNGARY

Euro Into Service

kazmér u.45

1121 Budapest

Tel. + Telefax : (1) 182.00 .44

ICELAND

Mál Mog Menning

Laugavegi 18, Pósthólf 392

121 Reykjavik

Tel. 162.35 .23

INDIA

Oxford Book and Stationery $\mathrm{Co}$

Scindia House

New Delhi 110001 Tel.(11) 331.5896/5308

Telefax: (11) 332.5993

17 Park Street

Calcutta 700016

Tel. 240832

INDONESIA

Pdii-Lipi
P.O. Box 269/JKSMG/88

Jakarta 12790

Tel. 583467

Telex: 62875

IRELAND

TDC Publishers - Library Suppliers

12 North Frederick Stree

Dublin 1

Tel. 74.48.35/74.96.77

ISRAEL

Electronic Publications only

Sophist Systems Ltd

71 Allenby Street

Tel. $3-29.00 .21$

Tel-Aviv, 65134

ITALY

Libreria Commissionaria Sanson

Via Duca di Calabria 1/1

50125 Firenze

Tel. (055) 64.54 .15

Via Bartolini 29 Telefax: (055) 64.12.57

20155 Milano

Tel. (02) 36.50 .83

Telefax: (02) 68.19 .00

PAKISTAN

Mirza Book Agency

65 Shahrah Quaid-E-Azam
Lahore 54000

\section{Tel.}

PHILIPPINE

International Book Center

5th Floor, Filipinas Life Bldg.

Ayala Avenue

Metro Manila

PORTUGAL

Livraria Portugal

Rua do Carmo 70-74

Rua do Carmo 2681

1117 Lisboa Codex Tel: (01) $347.49 .82 / 3 / 4 / 5$ Telefax: (01) 347.02 .64

SINGAPORE

Information Publications Pte. Ltd

41, Kallang Pudding, No. 04-03

Singapore 1334

Tel. 741.5166

Telefax: 742.9356

SPAIN

Mundi-Prensa Libros S.A.

Castello 37 , Apartado 1223

Madrid 28001 Tel. (91) 431.33.99 Telefax: (91) 575.39.98

Libreria Internacional AEDOS

Consejo de Ciento 391

08009 - Barcelona Tel. (93) 488.34.92 Telefax: (93) 487.76 .59

Llibreria de la Generalitat

Palau Moja

08002 - Barcelona (Subscripcions) Tel. (93) 318.80.12
(Publicacions) Tel. (93) 302.67.23 Telefax: (93) 412.18 .54
Rambla dels Estudis, 118

SRI LANKA

Centre for Policy Research

c/o Colombo Agencies Ltd

No. 300-304, Galle Road

Colombo 3 Tel. (1) $574240,573551-2$ Telefax: (1) 575394,51071

SWEDEN

Fritzes Fackboksföretaget

Box 16356

Regeringsgatan 12

10327 Stockholm

Tel. (08) 690.90 .90

Telefax: (08) 20.50.21

Subscription Agency

Wennergren-Williams AB 



Rigorous policy analysis is impossible without solid quantitative and institutional information, and the figures change all the time. The OECD's best-selling diskette

\section{OECD HEALTH DATA/ ÉCO-SANTÉ OCDE}

which contains the most important statistics on the health systems of the 24 member countries, has therefore been revised and updated. This is designed to allow up-to-the-minute macro-economic analysis of health-care systems in the OECD countries within the general demographic, health and social context.

The package, prepared jointly by OECD and CREDES, now contains some 200,000 data covering the period 1960-1991 and includes more than 300 series including, among others:

- Total Expenditure on Health

- Expenditure on Inpatient Care

- Expenditure on Medical Goods

- Hospital Facilities and Staff

- Employment and Earnings of Health Professions

- Demography

- Economic and Social Environment

- Length of Stay in Hospitals

- Frequency of Selected Treatments

- Health-Care Funding

- Expenditure and Utilisation

on Ambulatory Care

- Social Protection

- Hospital Throughplts

- Life Expectancy

- Life Styles

- Monetary Conversion Rates

- Surgical Procedures
The software on the diskette permits not only rapid consultation of data but also the creation of sophisticated tables, graphs, bar and pie charts with the possibility of retrieval and safeguard for later printing. It also allows the creation of maps.

Price: FF3,200 £355 US\$580 DM970

(special rates for academic circles, government bodies, hospital boards)

Send any order or request for free information brochure to:

\section{OECD Electronic Editions,}

2 rue André Pascal

75775 Paris Cedex 16, France;

fax (33-1) 452498 99; tel. (33-1) 45248165 ,

the OECD Publications and Information Centres in Washington, Tokyo, Bonn or to the OECD distributor in your country.






\section{OECD Publications}

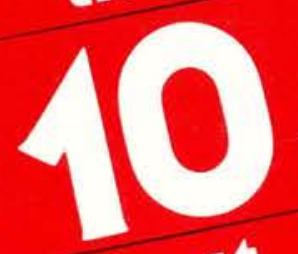

best

U.S.HEAUTH
U. sellers of the past

OECOD econoulic 25) THE REFO HEALTH CARE

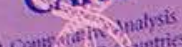
of sonthes

흔
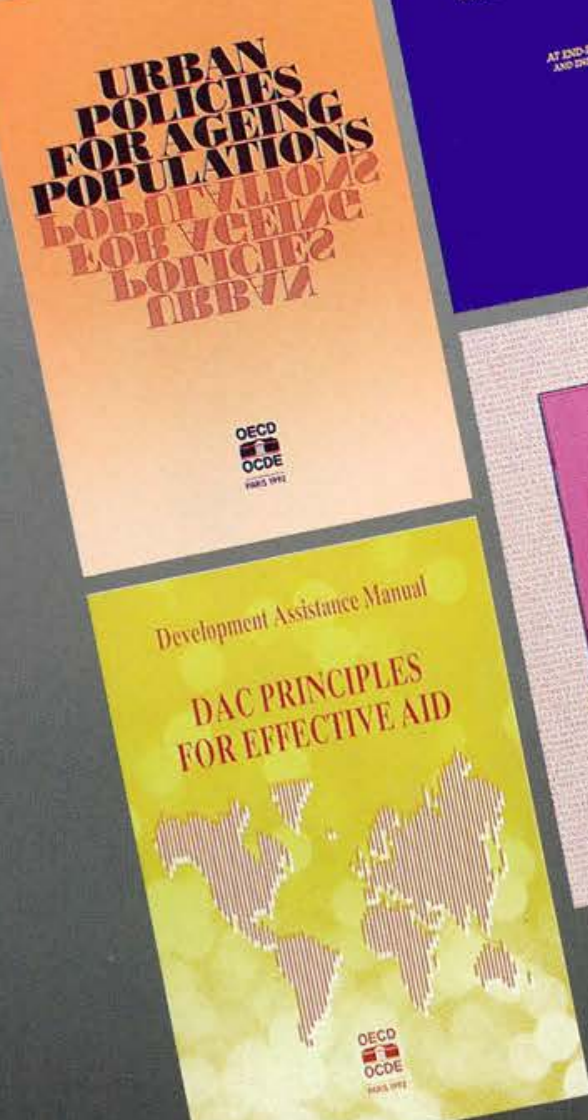

回 CARE AT THE ADS
CROSSROADS

2 months

(5)
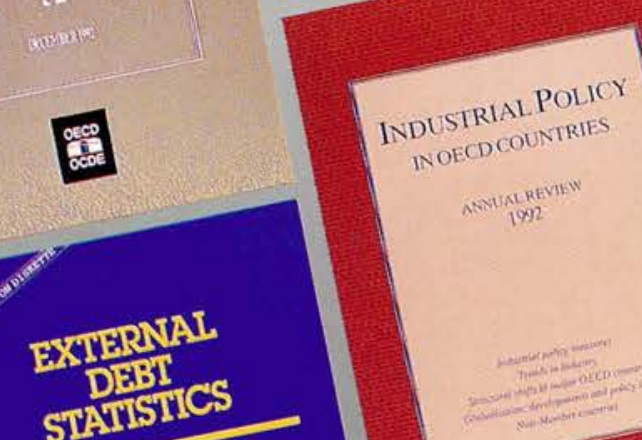

$1991 / 1992$



$$
\text { m }
$$
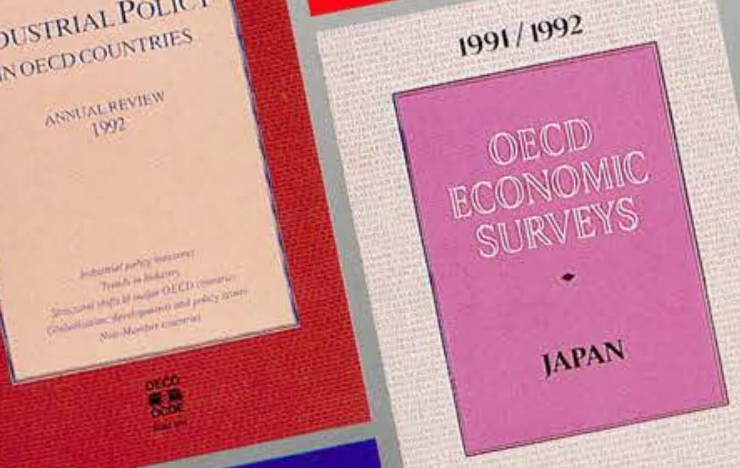

Q92 FEPOAT

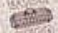

UNTED STATES



$-$ 